\title{
Carbon allocation and carbon isotope fluxes in the plant-soil-atmosphere continuum: a review
}

\author{
N. Brüggemann ${ }^{1}$, A. Gessler ${ }^{2}$, Z. Kayler ${ }^{2}$, S. G. Keel ${ }^{3}$, F. Badeck ${ }^{4}$, M. Barthel $^{5}$, P. Boeckx B. N. Buchmann $^{5}$, \\ E. Brugnoli $^{7}$, J. Esperschütz ${ }^{8,9}$, O. Gavrichkova ${ }^{7}$, J. Ghashghaie ${ }^{10}$, N. Gomez-Casanovas ${ }^{11}$, C. Keitel ${ }^{12}$, A. Knohl ${ }^{5,13}$, \\ D. Kuptz ${ }^{14}$, S. Palacio ${ }^{15}$, Y. Salmon ${ }^{16}$, Y. Uchida ${ }^{17}$, and M. Bahn ${ }^{18}$ \\ ${ }^{1}$ Forschungszentrum Jülich GmbH, Institute of Bio- and Geosciences, Agrosphere Institute (IBG-3), Leo-Brandt-Straße, \\ 52425 Jülich, Germany \\ ${ }^{2}$ Leibniz Centre for Agricultural Landscape Research, Institute for Landscape Biogeochemistry, Eberswalderstraße 84, \\ 15374 Müncheberg, Germany \\ ${ }^{3}$ Princeton University, Department of Ecology and Evolutionary Biology, 236 Guyot Hall, Princeton, NJ 08544, USA \\ ${ }^{4}$ Potsdam Institute for Climate Impact Research (PIK), P.O. Box 601203, 14412 Potsdam, Germany \\ ${ }^{5}$ ETH Zurich, Institute of Agricultural Sciences, Universitätsstrasse 2, 8092 Zürich, Switzerland \\ ${ }^{6}$ Gent University, Department of Applied Analytical and Physical Chemistry, Coupure Links 653, 9000 Gent, Belgium \\ ${ }^{7}$ Consiglio Nazionale delle Ricerche (CNR), Istituto di Biologia Agroambientale e Forestale (IBAF), Via G. Marconi 2, \\ 05010 Porano, Italy \\ ${ }^{8}$ Technische Universität München, Chair of Soil Ecology, Center of Food and Life Sciences Weihenstephan, \\ Ingolstädter Landstr. 1, 85764 Neuherberg, Germany \\ ${ }^{9}$ Helmholtz Zentrum München GmbH, German Research Center for Environmental Health, Department of Environmental \\ Genomics, Ingolstädter Landstr. 1, 85764 Neuherberg, Germany \\ ${ }^{10}$ Laboratoire d'Ecologie, Systématique et Evolution (ESE), CNRS AgroParisTech-UMR 8079, Bâtiment 362, Université de \\ Paris-Sud (XI), 91405 Orsay Cedex, France \\ ${ }^{11}$ University of Illinois at Chicago, Department of Biological Sciences, 845 West Taylor St, Chicago, IL 60607, USA \\ ${ }^{12}$ University of Sydney, Faculty of Agriculture, Food \& Natural Resources, 107 Cobbitty Rd., Cobbitty 2570, NSW, Australia \\ ${ }^{13}$ Georg-August-University Göttingen, Büsgen Institute, Chair of Bioclimatology, Büsgenweg 2, 37077 Göttingen, Germany \\ ${ }^{14}$ Technical University of Munich, Ecophysiology of Plants, Department of Ecology, Hans-Carl-von-Carlowitz-Platz 2, \\ 85354 Freising, Germany \\ ${ }^{15}$ Pyrenean Institute of Ecology (CSIC), Av. Regimiento Galicia s/n, Apdo. 64, Jaca, 22700 Huesca, Spain \\ ${ }^{16}$ University of Zurich, Institute of Evolutionary Biology and Environmental Studies, Winterthurerstrasse 190, \\ 8057 Zurich, Switzerland \\ ${ }^{17}$ National Institute for Agro-Environmental Sciences, 3-1-3 Kannondai, Tsukuba, 305-8604, Japan \\ ${ }^{18}$ University of Innsbruck, Institute of Ecology, Sternwartestraße 15, 6020 Innsbruck, Austria
}

Received: 7 March 2011 - Published in Biogeosciences Discuss.: 7 April 2011

Revised: 27 October 2011 - Accepted: 9 November 2011 - Published: 28 November 2011

\begin{abstract}
The terrestrial carbon (C) cycle has received increasing interest over the past few decades, however, there is still a lack of understanding of the fate of newly assimilated $\mathrm{C}$ allocated within plants and to the soil, stored within ecosystems and lost to the atmosphere. Stable carbon isotope studies can give novel insights into these issues. In this review we provide an overview of an emerging picture of plant-soil-atmosphere $\mathrm{C}$ fluxes, as based on $\mathrm{C}$ isotope
\end{abstract}

Correspondence to: N. Brüggemann (n.brueggemann@fz-juelich.de) studies, and identify processes determining related $\mathrm{C}$ isotope signatures. The first part of the review focuses on isotopic fractionation processes within plants during and after photosynthesis. The second major part elaborates on plantinternal and plant-rhizosphere $\mathrm{C}$ allocation patterns at different time scales (diel, seasonal, interannual), including the speed of $\mathrm{C}$ transfer and time lags in the coupling of assimilation and respiration, as well as the magnitude and controls of plant-soil $\mathrm{C}$ allocation and respiratory fluxes. Plant responses to changing environmental conditions, the functional relationship between the physiological and phenological status of plants and $\mathrm{C}$ transfer, and interactions between

Published by Copernicus Publications on behalf of the European Geosciences Union. 
$\mathrm{C}$, water and nutrient dynamics are discussed. The role of the $\mathrm{C}$ counterflow from the rhizosphere to the aboveground parts of the plants, e.g. via $\mathrm{CO}_{2}$ dissolved in the xylem water or as xylem-transported sugars, is highlighted. The third part is centered around belowground $\mathrm{C}$ turnover, focusing especially on above- and belowground litter inputs, soil organic matter formation and turnover, production and loss of dissolved organic $\mathrm{C}$, soil respiration and $\mathrm{CO}_{2}$ fixation by soil microbes. Furthermore, plant controls on microbial communities and activity via exudates and litter production as well as microbial community effects on $\mathrm{C}$ mineralization are reviewed. A further part of the paper is dedicated to physical interactions between soil $\mathrm{CO}_{2}$ and the soil matrix, such as $\mathrm{CO}_{2}$ diffusion and dissolution processes within the soil profile. Finally, we highlight state-of-the-art stable isotope methodologies and their latest developments. From the presented evidence we conclude that there exists a tight coupling of physical, chemical and biological processes involved in $\mathrm{C}$ cycling and $\mathrm{C}$ isotope fluxes in the plant-soil-atmosphere system. Generally, research using information from $\mathrm{C}$ isotopes allows an integrated view of the different processes involved. However, complex interactions among the range of processes complicate or currently impede the interpretation of isotopic signals in $\mathrm{CO}_{2}$ or organic compounds at the plant and ecosystem level. This review tries to identify present knowledge gaps in correctly interpreting carbon stable isotope signals in the plant-soil-atmosphere system and how future research approaches could contribute to closing these gaps.

\section{Introduction}

The flux of carbon dioxide between the atmosphere and the terrestrial biosphere and back is approx. 15-20 times larger than the anthropogenic release of $\mathrm{CO}_{2}$ (IPCC, 2007). This large bidirectional biogenic $\mathrm{CO}_{2}$ flux has a significant imprint on the carbon isotope signature of atmospheric $\mathrm{CO}_{2}$ (Randerson et al., 2002), which in turn helps to understand the controls of $\mathrm{CO}_{2}$ fluxes and to predict how they will respond to global change. There is a lack of knowledge on how plant physiological as well as soil biological, physical and chemical processes interact with and affect ecosystem processes, such as net ecosystem primary production and carbon sequestration as well as the larger scale carbon balance. The vegetation is not only the primary source of soil organic matter, thus contributing to long-term carbon accumulation in the organic soil layers, but it also determines belowground processes such as soil respiration over the short term through transport of photosynthates to the roots and to the soil (Bahn et al., 2010; Mencuccini and Hölttä, 2010; Högberg et al., 2010). For an assessment of the adaptability of stands and ecosystems as well as for the development of strategies for forest and landscape management that aims at minimizing the negative effects of the predicted climate and atmospheric composition changes and maintaining the carbon sequestration potential, we have to deepen our knowledge on the processes determining plant-arbon relations.

Due to the slight difference in atomic mass, physical and chemical properties of substances containing different stable isotopes (isotopologues, such as ${ }^{12} \mathrm{CO}_{2}$ and ${ }^{13} \mathrm{CO}_{2}$ ) vary, resulting in different reaction kinetics and thermodynamic properties. These result in the "preference" of chemical and physical processes for one isotopologue, usually the lighter one, over the other (e.g. preference for ${ }^{12} \mathrm{CO}_{2}$ over ${ }^{13} \mathrm{CO}_{2}$ ) and hence in so-called fractionation events, which change the isotopic composition of compounds involved in such processes. The carbon isotope composition is usually expressed in $\delta$ notation (in \%o units), relative to the international standard Vienna Pee Dee Belemnite (VPDB) (Hut, 1987). The carbon isotopic composition $\delta^{13} \mathrm{C}$ of any sample is thus expressed as deviation from VPDB as shown in Eq. (1):

$\delta^{13} \mathrm{C}=\frac{R_{\text {sample }}}{R_{\mathrm{VPDB}}}-1$

where $R$ is the isotope (abundance) ratio $\left({ }^{13} \mathrm{C} /{ }^{12} \mathrm{C}\right)$ of a given sample $\left(R_{\text {sample }}\right)$ and of VPDB $\left(R_{\mathrm{VPDB}}=0.0111802\right.$; from Werner and Brand, 2001), respectively.

The notation for isotope fractionation is the capital Greek letter $\Delta$. Carbon isotope discrimination $\left(\Delta^{13} \mathrm{C}\right)$ is defined as the depletion of ${ }^{13} \mathrm{C}$ during any process preferring the lighter isotopologue:

$$
\Delta^{13} \mathrm{C}=\frac{\delta^{13} \mathrm{C}_{\mathrm{s}}-\delta^{13} \mathrm{C}_{\mathrm{p}}}{1+\delta^{13} \mathrm{C}_{\mathrm{p}}}
$$

where $\delta^{13} \mathrm{C}_{\mathrm{s}}$ is the carbon isotope signature of the source (or the substrate entering a reaction; e.g. $\mathrm{CO}_{2}$ when photosynthetic fractionation is considered) and $\delta^{13} \mathrm{C}_{\mathrm{p}}$ is the isotopic signature of the product of a process (Farquhar et al., 1982).

Two major fractionation types can be distinguished, which are kinetic fractionation and equilibrium fractionation. Kinetic fractionation occurs during an irreversible process, either during physical events, like diffusion of $\mathrm{CO}_{2}$ in air or phase transitions with constant removal of one phase, or during chemical reactions, like the conversion of a substance to another, e.g. $\mathrm{CO}_{2}$ into plant carbohydrates. Equilibrium fractionation occurs when a chemical reaction or a physical process is reversible and continues to occur in both directions, and the different isotopes accumulate on either side of the reaction or process according to their mass-dependent binding energies in substrate(s) and product(s) or aggregate states, e.g. evaporation and condensation of $\mathrm{H}_{2} \mathrm{O}$.

As a result of the different isotope fractionation processes along the pathway of carbon from the atmosphere through the plant into the soil - associated with diffusion, phase transition and enzyme activities in leaves, non-green plant parts and soil - the natural abundance of carbon isotopes at different stages of the pathway is the key to understanding and 
integrating the complexity of atmosphere-plant-soil interactions in the global terrestrial carbon cycle and to predicting future atmospheric carbon dioxide levels under global change. The physiological information encoded in the isotope signature due to fractionation processes allows in principle to link changes in carbon metabolism on the biochemical scale with whole ecosystem carbon dynamics. In addition, the analysis of temporal variations in the isotopic composition of different chemical compounds in different ecosystem compartments provides a tool to assess the fate of carbon in plant, soil and atmosphere. However, as the isotopic signatures of carbon compounds transported in the plant-soil-atmosphere system do not necessarily remain unchanged during transport, it is important to know all relevant processes involved in generating and altering theses signatures. The aim of this review is to aggregate the stateof-the-art knowledge of carbon isotope fluxes and fractionation patterns in terrestrial ecosystems with a special emphasis on plant-soil interactions and their impact on soil carbon turnover and storage capacity.

\section{Carbon isotope fractionation in plants}

Mainly due to historical reasons carbon isotope fractionation in plants has been separated into photosynthetic carbon isotope fractionation, including $\mathrm{CO}_{2}$ diffusion, carboxylation, as well as dark and photorespiration (Farquhar et al., 1982), and into post-photosynthetic fractionation (von Caemmerer et al., 1997). However, if the distinction between the main fractionation step by Rubisco activity and all downstream fractionation steps should be made, the latter can be collectively addressed as post-carboxylation fractionation (Gessler et al., 2008), the terminology applied in the following. Figure 1 summarises photosynthetic and post-carboxylation carbon isotope fractionations (and some other processes such as mixing of sugars during phloem transport), which affect the carbon isotope composition of plant organic matter and respired $\mathrm{CO}_{2}$. In the following sections we will explore these particular processes, their effects on $\delta^{13} \mathrm{C}$ as well as the environmental and physiological information encoded in the isotopic signals.

\subsection{Photosynthetic carbon isotope fractionation and its temporal variation}

Generally, carbon isotope fractionation during photosynthesis ( 1 in Fig. 1) in $\mathrm{C}_{3}$ plants is described according to the following equation (Farquhar et al., 1982):

$$
\begin{aligned}
& \Delta{ }^{13} \mathrm{C}=a_{\mathrm{b}} \frac{p_{\mathrm{a}}-p_{\mathrm{s}}}{p_{\mathrm{a}}}+a \frac{p_{\mathrm{s}}-p_{\mathrm{i}}}{p_{\mathrm{a}}}+\left(e_{\mathrm{s}}+a_{\mathrm{l}}\right) \frac{p_{\mathrm{i}}-p_{\mathrm{c}}}{p_{\mathrm{a}}} \\
& +b \frac{p_{\mathrm{c}}}{p_{\mathrm{a}}}-\left(\frac{e R_{\mathrm{d}} / k}{p_{\mathrm{a}}}+\frac{f \Gamma *}{p_{\mathrm{a}}}\right)
\end{aligned}
$$

where $p_{\mathrm{a}}, p_{\mathrm{s}}, p_{\mathrm{i}}$ and $p_{\mathrm{c}}$ are the $\mathrm{CO}_{2}$ partial pressures in ambient air, at the leaf surface, in the leaf intercellular airspace

\section{Isotope composition Fractionation and other processes affecting the isotope composition}

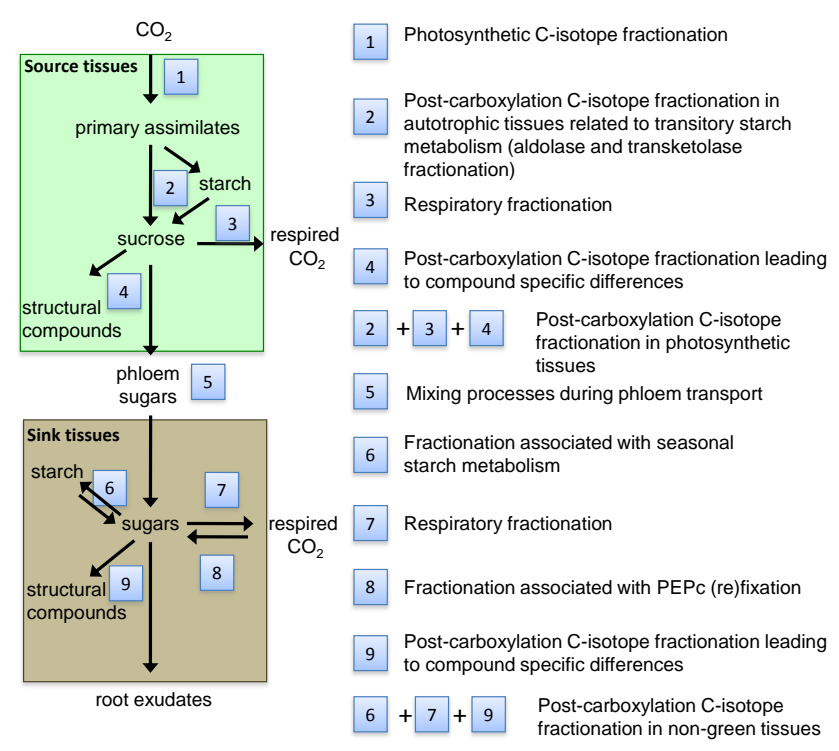

Fig. 1. Summary of the plant-related processes that potentially influence the carbon isotopic composition of organic matter and $\mathrm{CO}_{2}$. Carbon isotope fractionation and other processes (i.e. mixing of pools), which influence the isotope composition are listed on the right side of the figure. In addition to the listed fractionation processes, the carbon isotope composition of atmospheric $\mathrm{CO}_{2}$ influences $\delta{ }^{13} \mathrm{C}$ of organic matter. The figure is adapted from Gessler et al. (2009b).

and in the chloroplasts, respectively. $a_{\mathrm{b}}$ and $a$ describe the carbon isotope fractionation during diffusion through the boundary layer $(2.9 \%$ ) and into the leaves through the stomata $(4.4 \%)$, respectively. $e_{\mathrm{s}}$ is the fractionation occurring as $\mathrm{CO}_{2}$ enters an aqueous solution $\left(1.1 \%\right.$ at $\left.25^{\circ} \mathrm{C}\right)$ and $a_{1}$ the fractionation during diffusion through the liquid phase $\left(0.7 \% \circ\right.$ at $\left.25^{\circ} \mathrm{C}\right), k$ is the carboxylation efficiency and $b$ the net fractionation during carboxylation. $R_{\mathrm{d}}$ is the respiration rate in the light, $\Gamma *$ is the $\mathrm{CO}_{2}$ compensation point in the absence of day respiration, and $e$ and $f$ are the fractionation factors during day respiration and photorespiration. The mechanisms of photosynthetic carbon isotope fractionation have been reviewed elsewhere (Farquhar et al., 1989; Brugnoli and Farquhar, 2000), so that only some central points are discussed here.

In literature, often a simplified version of the model presented in Eq. (3), assuming a two-stage model (diffusion through the stomata followed by carboxylation, is applied to estimate photosynthetic carbon isotope fractionation:

$\Delta_{\mathrm{i}}=a+(b-a) \frac{p_{\mathrm{i}}}{p_{\mathrm{a}}}$

Due to the relationship between photosynthetic carbon isotope fractionation and the ratio of intercellular airspace 
and ambient $\mathrm{CO}_{2}$ partial pressures $\left(p_{\mathrm{i}} / p_{\mathrm{a}}\right)$, which is often expressed as a $\mathrm{CO}_{2}$ concentration ratio $\left(c_{\mathrm{i}} / c_{\mathrm{a}}\right)$, newly assimilated organic matter can be generally used to characterise environmental effects on the physiology of photosynthesis. Stomatal closure due to water deficit generally reduces $c_{\mathrm{i}}$, leading to an increase in $\delta^{13} \mathrm{C}$ (e.g. Farquhar et al., 1982; Korol et al., 1999). As light limitation of photosynthesis increases $c_{\mathrm{i}}, \delta^{13} \mathrm{C}$ can also depend on radiation (Leavitt and Long, 1986; McCarroll and Pawellek, 2001) under particular conditions, but also combined influences of water and light availability have been observed (Gessler et al., 2001).

Von Caemmerer and Evans (1991) established the relation between assimilation rate $(A)$ and mesophyll (internal) $\mathrm{CO}_{2}$ transfer conductance $\left(g_{\mathrm{m}}\right)$ as follows:

$A=\frac{g_{\mathrm{m}}\left(p_{\mathrm{i}}-p_{\mathrm{c}}\right)}{P}$

where $P$ is the atmospheric pressure. However, only recently it was observed that $g_{\mathrm{m}}$ and its reaction to environmental conditions can vary among functional plant groups (Warren, 2008), and also within cultivars of a particular species (Flexas et al., 2008), not strictly related to $A$. In addition, $g_{\mathrm{m}}$ of a given species and/or cultivar might change with plant and leaf age. Such changes in $g_{\mathrm{m}}$ might partially constrain the application of the simplified carbon isotope fractionation models (Warren and Adams, 2006; Gessler et al., 2008). Since mesophyll conductance is not included in the widely used two-step model (Eq. 4) for photosynthetic carbon isotope fractionation (Farquhar et al., 1982), and $p_{\mathrm{i}}$ and not the $\mathrm{CO}_{2}$ partial pressure inside the chloroplast $\left(p_{\mathrm{c}}\right)$ is used as a basis for calculation, any variation in $g_{\mathrm{m}}$ will constrain the classical way of calculating carbon isotope fractionation (Seibt et al., 2008) when the relationship between $g_{\mathrm{m}}$ and assimilation rate is not constant (Warren and Adams, 2006).

Similarly, it has been shown by several authors (see Gillon and Griffiths, 1997; Igamberdiev et al., 2004; Tcherkez, 2006) that the isotope effect associated with photorespiration can be quite high $(f \approx 10 \%)$ and thus can have a significant impact given that $\Gamma^{*} / p_{\text {a }}$ equals approx. 0.1. In contrast, the day respiratory fractionation, $e$, is thought to be less significant because the factor $R_{\mathrm{d}} /\left(k p_{\mathrm{a}}\right)$ is much smaller (typically 0.02).

Carbon isotope discrimination related to $\mathrm{C}_{4}$ photosynthesis is much smaller and less variable compared to the $\mathrm{C}_{3}$ pathway. Net fractionation of the $\mathrm{CO}_{2}$ fixation by the enzyme phosphoenolpyruvate carboxylase (PEPc) in the mesophyll cell is $-5.7 \%$, i.e. there is a discrimination against the lighter carbon, ${ }^{12} \mathrm{C}$ (Farquhar, 1983). This is mainly due to the fact that PEPc uses $\mathrm{HCO}_{3}^{-}$as substrate and the dissolution plus hydration of $\mathrm{CO}_{2}$ enriches ${ }^{13} \mathrm{C}$ in $\mathrm{HCO}_{3}^{-}$by $7.9 \%$ \% (at $25^{\circ} \mathrm{C}$; Mook et al., 1974), and that PEPc discriminates by only $2.2 \%$ against ${ }^{13} \mathrm{C}$. The PEPc-fixed $\mathrm{CO}_{2}$ will be released again in the bundle sheath cells, where it is re-fixed by Rubisco. Since part of the $\mathrm{CO}_{2}$ released in the bundle sheath tissue leaks out to the mesophyll (Hatch, 1995), a (metabolic) branching point is formed, which allows ${ }^{13} \mathrm{C}$ discrimination by Rubisco (Farquhar, 1983). Farquhar (1983) developed the following (simplified) equation to describe the carbon isotope discrimination of $\mathrm{C}_{4}$ photosynthesis:

$\Delta=a+\left(b_{4}+b_{3} \phi-a\right) \frac{p_{\mathrm{i}}}{p_{\mathrm{a}}}$

where $\mathrm{b}_{4}$ describes the discrimination of the fixation of gaseous $\mathrm{CO}_{2}$ in equilibrium with $\mathrm{HCO}_{3}^{-}$(at $25^{\circ} \mathrm{C}$ ) by PEPc (for details see Farquhar, 1983 and Farquhar et al., 1989), $\phi$ is the relative proportion of the carbon fixed by PEPc that leaks out of the bundle sheath ("bundle sheath leakiness"; Farquhar, 1983) and $b_{3}$ describes the discrimination by Rubisco.

The Crassulacean acid metabolism (CAM) as a particular modification of the photosynthetic carbon fixation also imprints a specific carbon isotope signal on the assimilates (O'Leary, 1988). The most simple description of the CAM according to Lüttge (2004) is that there is nocturnal uptake of $\mathrm{CO}_{2}$ via open stomata, $\mathrm{CO}_{2}$ fixation by PEPc and vacuolar storage of organic acid assimilates, mainly malic acid (phase I; Osmond, 1978), and daytime remobilization of vacuolar organic acids, decarboxylation and re-fixation of the released $\mathrm{CO}_{2}$ behind closed stomata by Rubisco (phase III). The malate stored at night will show the same discrimination as for $\mathrm{C}_{4}$ species without bundle sheath leakiness and since $\mathrm{CO}_{2}$ evolution during phase III is assumed to be negligible, the carbon isotope discrimination in phase I and III might be described by Eq. 6 assuming $\phi$ to be 0 (Farquhar et al., 1989). In the early light period (phase II) and in the late light period, when organic acids are exhausted (phase VI), however, stomata are open and external $\mathrm{CO}_{2}$ can be fixed by Rubisco (Osmond, 1978; Farquhar et al., 1989). Both, phase II and phase IV are very sensitive to environmental parameters (Lüttge 2004) and thus the relative contribution of PEPc(phase II and III) and Rubisco-driven (mainly phase IV) discrimination might also vary with the environment.

High variations of photosynthetic carbon isotope fractionation in $\mathrm{C}_{3}$ species over the day, between days and over the growing season were recently revealed by direct online isotope measurements under field conditions, which allow data acquisition with high temporal resolution by applying novel laser spectroscopy techniques (Wingate et al., 2010). Over the whole growing season, photosynthetic carbon isotope fractionation for branches of maritime pine at a field site in France amounted to 10 to $35 \%$. These values agree well with the range of photosynthetic carbon isotope fractionation under various light conditions determined for wheat and bean under controlled conditions (Gillon and Griffiths, 1997). The highest values typically occurred at dusk throughout the growing season, but also in the early morning of June and July and throughout the day during the winter months. During summer, diel variations of photosynthetic fractionation amounted to more than $15 \%$ (Wingate et al., 2010). Changes in weather conditions among days also 
caused clear variations in $\delta^{13} \mathrm{C}$, which then could be traced in the newly produced organic matter transported through the plant. On the basis of day-to-day variations in the photosynthetic carbon isotope fractionation as occurring in $\mathrm{C}_{3}$ plants, the transport of new assimilates through the plant and within the ecosystem has been tracked as soil respired $\mathrm{CO}_{2}$ (Ekblad and Högberg, 2001; Knohl et al., 2005; Mortazavi et al., 2005; Brandes et al., 2006; Gessler et al., 2007) and transport times have been assessed (Mencuccini and Hölttä, 2010) (see 3.4). As demonstrated by Brandes et al. (2007) and Wingate et al. (2010), such techniques can be applied throughout the whole growing season and have the additional advantage compared to ${ }^{13} \mathrm{C}$ pulse labeling experiments - that the information on leaf physiology encoded in $\delta^{13} \mathrm{C}$ can be additionally analysed. As mentioned above and discussed by Warren and Adams (2006), it might, however, not be possible to directly relate $\delta^{13} \mathrm{C}$ to $p_{\mathrm{i}} / p_{\mathrm{a}}$ or water-use efficiency in $\mathrm{C}_{3}$ species due to potential variations in $g_{\mathrm{m}}$. Despite this potential constraint, $\delta^{13} \mathrm{C}$ of basipetally transported assimilates have been successfully applied to characterise variation in stomatal conductance in different tree species (e.g. Cernusak et al., 2003; Scartazza et al., 2004; Keitel et al., 2006).

However, it also has to be stated that the natural abundance technique failed tracking the fate of new assimilates in particular species mainly when environmental conditions were not very different among days (Kodama et al., 2008, 2011). It has been suggested that post-carboxylation fractionation and mixing of sugars of different metabolic history during phloem transport might blur the rather weak initial isotopic signal from photosynthetic fractionation in these cases.

\subsection{Post-carboxylation fractionation}

Post-carboxylation isotopic fractionation is defined as all isotope effects associated with the metabolic pathways downstream Rubisco carboxylation and with export of organic matter out of particular tissues (Hobbie and Werner, 2004; Badeck et al., 2005). Fractionation due to equilibrium and kinetic isotope effects results in differences in isotopic signatures between metabolites and in intramolecular isotopic distribution (Schmidt, 2003; Tcherkez and Farquhar, 2005). Post-carboxylation fractionation is also thought to be responsible for differences in $\delta^{13} \mathrm{C}$ between plant organs (for a recent review see Cernusak et al., 2009). Beside photosynthetic also post-carboxylation carbon isotope fractionation might account for diel variations in the isotopic composition of carbon exported from the leaves to heterotrophic tissues (Tcherkez et al., 2004; Brandes et al., 2006) and of respired $\mathrm{CO}_{2}$ (Tcherkez et al., 2003; Werner and Gessler, 2011). The following section will give an overview of the main fractionation mechanisms and the consequences for research on plant and ecosystem carbon balances.

One of the first post-carboxylation fractionation steps occurs in the Calvin cycle during aldolase condensation (i.e. synthesis of fructose 1,6-bisphosphate from triose phosphates), enriching ${ }^{13} \mathrm{C}$ in the $\mathrm{C}-3$ and $\mathrm{C}-4$ atom positions of hexoses while leaving behind the light triose phosphates (Rossmann et al., 1991; Gleixner and Schmidt, 1997). A model developed by Tcherkez et al. (2004) and based on the isotope effects of both aldolase, reported by Gleixner and Schmidt (1997), and transketolase (estimated values), fits well the reproducible non-statistical ${ }^{13} \mathrm{C}$ distribution in hexose molecules reported by Rossmann et al. (1991). The intra-molecular carbon isotope distribution in Calvin cycle hexoses also depends on the relative activity of the glyoxylate cycle (photorespiration) because of decarboxylation of a ${ }^{13} \mathrm{C}$-rich carbon atom position and fractionation during glycine decarboxylation (Tcherkez et al., 2004). This intra-molecular ${ }^{13} \mathrm{C}$ pattern in hexose and thus in pyruvate molecules is considered to be the main origin of the so-called "fragmentation fractionation" (see Tcherkez et al., 2004) during dark respiration, which will be discussed below.

Another effect of the fractionation by aldolase and transketolase is the ${ }^{13} \mathrm{C}$-enrichment in transitory starch in the chloroplasts (2 in Fig. 1) and ${ }^{13} \mathrm{C}$-depletion in cytosolic sucrose (Schmidt and Gleixner, 1998). Indeed, as explained above, the fractionations of these enzymes in the Calvin cycle favour ${ }^{13} \mathrm{C}$ in hexoses and thus in transitory starch in the chloroplasts while leaving behind ${ }^{13} \mathrm{C}$-depleted trioses, which will form sucrose in the cytosol. Accordingly, the phloem sugars are ${ }^{13} \mathrm{C}$-enriched during night-time (originating from transitory starch degradation), while the daytime sugars in the phloem originating from the trioses left behind by aldolase/transketolase reactions are ${ }^{13} \mathrm{C}$-depleted. Such a diel change in ${ }^{13} \mathrm{C}$ content of phloem sugars modelled by Tcherkez et al. (2004) was observed experimentally by Gessler et al. (2008) in Ricinus plants.

Data available in the literature on the carbon isotope difference between starch and sugars (mainly sucrose) are scarce, and experimental protocols for their determination still need to be scrutinized (Richter et al., 2009). However, expected technical progress will open new avenues for studies of the variability of fractionation due to transitory starch synthesis with the rate of starch synthesis and with environmental conditions (Tcherkez et al., 2004). Thus, measurements of intramolecular patterns of $\delta^{13} \mathrm{C}$ and diel variation in sugar $\delta^{13} \mathrm{C}$ can potentially be used in ecological studies as indicators of assimilate allocation.

Carbon isotope fractionation during plant respiration (3 and 7 in Fig. 1) is a widely observed phenomenon (see reviews by Ghashghaie et al., 2003; Badeck et al., 2005; Bowling et al., 2008; Werner and Gessler, 2011). There are several enzyme-catalyzed reactions involved in respiratory metabolism that can lead to isotope fractionation.

Due to the non-statistical ${ }^{13} \mathrm{C}$ distribution in glucose, the $\delta^{13} \mathrm{C}$ of respired $\mathrm{CO}_{2}$ highly depends on the intra-molecular position of the $\mathrm{C}$ atom used for decarboxylation. Consequently, $\mathrm{CO}_{2}$ produced during different respiratory processes is often relatively enriched or depleted in ${ }^{13} \mathrm{C}$ compared to the associated substrate (Ghashghaie et al., 2003). This 
fragmentation fractionation (Tcherkez et al., 2004) may occur at a number of metabolic branching points along plant respiratory pathways (Barbour and Hanson, 2009).

Decarboxylation of pyruvate by the pyruvate dehydrogenase complex (PDH), coupled to the glycolysis pathway, releases relatively ${ }^{13} \mathrm{C}$-enriched $\mathrm{CO}_{2}$, using the $\mathrm{C}-3$ and $\mathrm{C}-4$ atoms of glucose (DeNiro and Epstein, 1977; Melzer and Schmidt, 1987). Consequently, acetyl-CoA is relatively depleted in ${ }^{13} \mathrm{C}$, as are fatty acids or $\mathrm{CO}_{2}$ released during the tricarboxylic acid cycle (TCA). Partitioning acetyl-CoA to fatty acid synthesis and TCA leads to an overall higher contribution of PDH than TCA activity to total $\mathrm{CO}_{2}$ efflux, which may explain the often-observed ${ }^{13} \mathrm{C}$-enrichment of $\mathrm{CO}_{2}$ efflux compared to respiratory substrate (Ghashghaie et al., 2003). Imbalances between TCA and PDH may also account for diel changes in $\delta^{13} \mathrm{C}$ of plant respiration (Kodama et al., 2008; Priault et al., 2009; Kodama et al., 2011). In addition, fractionation by PDH and TCA cycle enzymes may further change the isotopic signature of respired $\mathrm{CO}_{2}$ (Tcherkez and Farquhar, 2005). These effects depend on the relative flux strengths at the associated metabolic branching points, and only recently Werner et al. (2011) argued that the impermeability of the inner chloroplast membrane for acetyl-CoA as well as the channeling principle of the TCA cycle enzymes prevent the enzymatic reactions in the TCA cycle to effectively fractionate against ${ }^{13} \mathrm{C}$ in vivo.

Another decarboxylation reaction of glucose takes place within plastids during the oxidative stage of the pentose phosphate pathway (PPP). The PPP releases ${ }^{13} \mathrm{C}$-depleted C1 atoms of glucose as $\mathrm{CO}_{2}$ (Dieuaide-Noubhani et al., 1995; Bathellier et al., 2009). Moreover, this decarboxylation reaction fractionates against ${ }^{13} \mathrm{C}$ by about $9.6 \%$ (kinetic isotope effect; Rendina et al., 1984) or against ${ }^{12} \mathrm{C}$ by $4 \%$ o (equilibrium isotope effect; Rendina et al., 1984). Accordingly, the $\delta^{13} \mathrm{C}$ of $\mathrm{CO}_{2}$ produced during PPP is relatively depleted in ${ }^{13} \mathrm{C}$ compared to respiratory substrate. High PPP activity reported for roots could explain the ${ }^{13} \mathrm{C}$ depletion in root-respired $\mathrm{CO}_{2}$ (Bathellier et al., 2008) compared to ${ }^{13} \mathrm{C}$-enriched $\mathrm{CO}_{2}$ respired by leaves (Duranceau et al., 1999; Tcherkez et al., 2003).

High activity of PEPc is also known to occur in roots $(8$ in Fig. 1) and has also been detected also in aboveground $\mathrm{C}_{3}$ plant tissues (Berveiller and Damesin, 2008; Gessler et al., 2009a). PEPc carboxylates PEP using $\mathrm{HCO}_{3}^{-}$as substrate (stemming either from respiratory or external $\mathrm{CO}_{2}$ ) to malic acid (via oxaloacetate), which may enter the mitochondria to sustain TCA activity. This so-called "anaplerotic" supply is assumed to refill the TCA when citrate intermediates of the TCA are used, e.g. for amino acid synthesis (Tcherkez and Hodges, 2008; Bathellier et al., 2009). Net discrimination of PEPc against ${ }^{12} \mathrm{C}$ of $5.7 \%$ (including the equilibrium hydration of $\mathrm{CO}_{2}$ ) (Farquhar, 1983), enriches organic matter in ${ }^{13} \mathrm{C}$ and leaves ${ }^{13} \mathrm{C}$-depleted $\mathrm{CO}_{2}$ molecules behind (Gessler et al., 2009a), as long as malic acid is not immediately decarboxylated again (Cernusak et al., 2009). Consequently, the high ${ }^{13} \mathrm{C}$ enrichment of respiratory $\mathrm{CO}_{2}$ evolved from leaves shortly after darkening may be explained by rapid decarboxylation of highly ${ }^{13} \mathrm{C}$-enriched malic acid pools, derived from PEPc during illumination (light-enhanced dark respiration - LEDR; see Barbour et al., 2007). However, the overall quantitative effect of the before-mentioned fractionation processes in combination with temporal changes in the respiratory substrates on $\delta^{13} \mathrm{C}$ of plant $\mathrm{CO}_{2}$ efflux is still a matter of debate (Tcherkez, 2010; Werner, 2010; Werner et al., 2011).

It is now well established that plant organs differ in their isotopic signature. Several recent reviews (Badeck et al., 2005; Bowling et al., 2008; Cernusak et al., 2009) have shown that heterotrophic organs (branches, stems and roots) are enriched in ${ }^{13} \mathrm{C}$ compared to autotrophic organs, which supply them with carbon. Branches and woody stems of $\mathrm{C}_{3}$ species are on average $1.9 \%$ enriched in ${ }^{13} \mathrm{C}$ compared to leaves (Badeck et al., 2005), whereas roots show an average enrichment varying between 1.1\%o (Badeck et al., 2005) and $2 \%$ (Bowling et al., 2008). Several mechanisms have been proposed to explain these differences in isotopic signatures of plant organs (cf. Badeck et al., 2005, and Cernusak et al., 2009 , for detailed review of these processes). One of the reasons for differences in ${ }^{13} \mathrm{C}$ content between different plant organs is that the metabolites used for export (e.g. sucrose) are enriched in ${ }^{13} \mathrm{C}$ with respect to the photosynthetic products, leading to differences in ${ }^{13} \mathrm{C}$ content of heterotrophic tissues compared with leaves. Fragmentation of molecules with heterogeneous intra-molecular ${ }^{13} \mathrm{C}$ distribution and kinetic isotope effects at metabolic branching points associated with the enzymatic reactions leading to the respective products are known to cause compound-specific differences (4 and 9 in Fig. 1). When compounds, which become ${ }^{13} \mathrm{C}$-depleted as a consequence of such processes (e.g. lipids), remain in the leaves, whereas relatively ${ }^{13} \mathrm{C}$-enriched compounds are exported, the inter-organ differences will then be related to the chemical composition of organs.

Other potential reasons for organ-specific differences in $\delta^{13} \mathrm{C}$ might be seasonal asynchrony of growth of photosynthetic and heterotrophic tissues, with corresponding variation in photosynthetic discrimination against ${ }^{13} \mathrm{C}$ due to different environmental and ontogenetic conditions (Bathellier et al., 2008; Salmon et al., 2011), and developmental variation in photosynthetic fractionation against ${ }^{13} \mathrm{C}$ during leaf expansion. In addition, seasonal variations in starch storage and remobilisation (6 in Fig. 1) and the preferential use of ${ }^{13} \mathrm{C}$-enriched, starch-derived organic matter in a particular organ might be responsible for more positive $\delta^{13} \mathrm{C}$ values. As, however, also ${ }^{13} \mathrm{C}$ enrichment of particular compounds (e.g. phloem sucrose) was detected in basipetal direction (Gessler et al., 2009b), independent of ontogeny or development, other additional factors must be responsible for this observation. These might include differential use of daytime vs. night-time sucrose between leaves and sink tissues, with daytime sucrose being relatively ${ }^{13} \mathrm{C}$-depleted 
and night-time sucrose ${ }^{13} \mathrm{C}$-enriched (Tcherkez et al., 2004), as well as fractionation associated with the transport of assimilates (see 3.1). In addition, differences in fractionation during dark respiration in heterotrophic vs. autotrophic tissues (Bathellier et al., 2008), and higher carbon fixation by PEP carboxylase in roots might explain the inter-organ differences. The organ-specific spatial variation of the carbon isotope signal, i.e. the basipetal enrichment, which is not necessarily constant over the growing season (Gessler et al., $2009 \mathrm{~b}$ ), challenges the calculation of intrinsic water-use efficiency or $p_{\mathrm{i}} / p_{\mathrm{a}}$ from organic material of heterotrophic organs (e.g. in tree rings). However, temporal variations in $\delta^{13} \mathrm{C}$ of organic matter and respired $\mathrm{CO}_{2}$ as a consequence of post-carboxylation isotope fractionation have been related to starch synthesis and remobilization (e.g. Tcherkez et al., 2004) and other switches between metabolic pathways (Priault et al., 2009) and may, therefore, provide a way to identify changes in metabolic processes related to changes in carbon allocation patterns in plants and ecosystems.

In conclusion, post-carboxylation fractionation produces additional changes and variations in carbon isotope signals on top of the original photosynthetic signal. On the one hand, this complicates the tracking of the fate of carbon within the plant-soil system and might partially uncouple the isotope composition in heterotrophic tissues from leaf level processes. On the other hand, the post-carboxylation isotope fractionation processes are likely to give additional information on processes in heterotrophic tissues. It is, however, crucial to disentangle particular processes as well as their dependency on environmental and plant physiological processes and to quantify their contribution to post-carboxylation isotope fractionation. Moreover it is urgently needed to link the plant-level processes, assessed with isotope techniques, with processes at the ecosystem level.

\section{Carbon allocation in the plant-soil system}

As reviewed in Sect. 2, stable carbon isotope ratios of recently assimilated $\mathrm{C}$ contain valuable information about environmental conditions, which can be tracked through the plant-soil system and are imprinted in respired $\mathrm{CO}_{2}$. The process of $\mathrm{C}$ transport in the plant itself is not assumed to fractionate against the ${ }^{13} \mathrm{C}$-isotopologues of the transported compounds. However, temporal changes in $\mathrm{C}$ allocation and metabolic processes along the transport pathways can strongly affect this relationship between environmental conditions and $\delta^{13} \mathrm{C}$. For example, it has been observed that phloem sucrose is ${ }^{13} \mathrm{C}$-enriched in the trunk compared to the twig phloem of trees (e.g. Brandes et al., 2006, 2007). It is likely that metabolic processes associated with phloem transport (such as phloem loading, unloading and mixing; 5 in Fig. 1) but not the transport itself is responsible for these patterns. Since phloem-allocated sucrose is the main carbon source for all processes in non-green plant parts, spatial variations in $\delta^{13} \mathrm{C}$ along the plant axis and the processes involved need to be taken into account when interpreting respiratory isotope signals. Moreover, transport dynamics determine the coupling of the isotope signals aboveand belowground and thus an understanding of the underlying processes is crucial to interpret carbon isotope signals on the ecosystem scale. In the following section, studies are reviewed and discussed that document how $\mathrm{C}$ allocation in the plant-soil system varies on diel, seasonal and annual to interannual time scales and how these variations can influence isotope signals in plant biomass and soil respiration.

\subsection{Plant-internal C allocation}

Carbon transport through the phloem and xylem, and the underlying physiological mechanisms as affected by environmental and plant-internal factors, are a major point of uncertainty in understanding the patterns of assimilate distribution within plants and of plant-soil C coupling. Partitioning of the newly assimilated carbohydrates within the plant occurs via loading of sugars into the phloem, transport in the sieve tube system and unloading at the sites of demand. The pressure-driven mass flow system of the phloem allows $\mathrm{C}$ compounds to be transported over long distances in the plant from source to sink tissues (Van Bel, 2003). Consequently, the $\mathrm{C}$ partitioning is controlled by the supply of assimilates via photosynthesis, but also depends on the ability of different organs to utilise the available supply (Wardlaw, 1969). While these general principles are well known, the molecular background of the regulation of carbohydrate partitioning and of the transporters involved is less understood (Slewinski and Braun, 2010). Redox control of sugar transport and sugar plus phytohormone signalling seem to be at least involved in coordinating carbohydrate partitioning (Rolland et al., 2006). In such a manner, whole plant physiology can also exert a feedback sink control over leaf level photosynthesis, even overriding direct control by light and $\mathrm{CO}_{2}(\mathrm{Paul}$ and Foyer, 2001).

Considering the phloem just as a static tube for organic matter transport is inappropriately simplified (Fisher, 2002). The modified dynamic version of the Münch mass flow model (Münch, 1930), as reviewed by Van Bel (2003), assumes that assimilates are translocated in the plant via the phloem through "leaky pipes" - a metaphor for the sieve tube-companion cell complexes. According to this model, the solute content in the phloem and, as a consequence, the pressure are controlled by release/retrieval mechanisms in the sieve element/companion cell complexes. During transport, sugars are released from the sieve tubes and part of them are retrieved again (Minchin and Thorpe, 1987). This mechanism of carbon release and partial retrieval might also explain the often observed ${ }^{13} \mathrm{C}$ enrichment of phloem sugars during transport in basipetal direction (Gessler et al., 2009b). Part of the sugars released might undergo metabolic conversion in reactions fractionating against the heavier isotopologue. 
Due to mass balance reasons the unreacted sugars, which are reloaded in the phloem, will be ${ }^{13} \mathrm{C}$-enriched (Hobbie and Werner, 2004).

The differential release/retrieval balances in the phloem not only control the net influx or efflux of sugars, but also the flux of water in different phloem zones. In the collection phloem in source tissues, the influx of sugars and water will dominate, whereas in the release phloem in the sink tissues the efflux of sugars and water will prevail. In summary, as in the original Münch model, the driving force to control phloem transport is the source-sink turgor difference. In contrast, Thompson (2006) assumes that the "inability of decentralized organisms such as plants to control phloem translocation centrally disqualifies such [pressure] differentials as control variables". In addition, the author argues that the maximum efficiency of phloem transport is achieved if the pressure differentials are small, and that homogeneous turgor and rapid long-distance distribution of local disturbances in turgor and solute concentration are a prerequisite for the sieve element/companion cell complexes to operate in a noncentralized manner and to serve both long distance transport and local supply of surrounding tissues.

Mencuccini and Hölttä (2010) advanced towards a mechanistic understanding of the phloem as a "bottleneck" to C flow below ground. They provide evidence that specific phloem properties (path length, specific conductivity and turgor pressure differences) and transport velocities are crucial to explain the linkage between canopy photosynthesis and belowground processes. Furthermore, they put forward the hypothesis of Ferrier et al. (1975) and Thompson and Holbrook (2004) that pressure/concentration waves travelling through the phloem are responsible for a very fast transfer of information, coupling assimilation to belowground processes. Pressure wave fronts are assumed to travel several orders of magnitude faster than the phloem solution and the solutes within, thus creating a signal that is rapidly transferred through the plant via the phloem. If pressure concentration waves completely mediated the coupling between (canopy) carbon assimilation and soil respiration, the tracking of isotope signals - either as natural abundance isotope composition or as highly enriched ${ }^{13} \mathrm{C}$ label - would not be suited to characterize this link (Mencuccini and Hölttä, 2010). Soil respiration as an example would already be upregulated hours or days before the newly assimilated substrate arrives belowground and could imprint its $\delta^{13} \mathrm{C}$ signature upon the respired $\mathrm{CO}_{2}$. Kayler et al. (2010a) postulated, however, that the time of arrival of carbon molecules belowground conveys more important information than a hypothetic pressure concentration wave. This is because the time it takes for a carbon molecule to pass through the plant indicates the status of plant storage pools, the impact of water availability on biological activity and plant nutrient status. The authors thus concluded that the time-lag between carbon fixation during photosynthesis and its loss through respiration belowground carries real physiological information about the carbon use within plants as well as about the degree to which plants and soil are coupled and that this information is exactly the one derived from studies of the isotopic composition of recent assimilates, other short- or long-lived carbon pools and respired $\mathrm{CO}_{2}$.

The time lag caused by $\mathrm{C}$ translocation from leaves to belowground sites of respiration has been extensively reviewed (Davidson and Holbrook, 2009; Kuzyakov and Gavrichkova, 2010; Mencuccini and Hölttä, 2010) since photosynthesis has been identified as a key driver of soil respiration (Högberg et al., 2001). Generally, time lags determined as propagation of fluctuations in $\delta^{13} \mathrm{C}$ at natural abundance increase with tree height, with transport rates between 0.07 and $0.5 \mathrm{~m} \mathrm{~h}^{-1}$ (Kuzyakov and Gavrichkova, 2010; Mencuccini and Hölttä, 2010), although carbon translocation velocities are often higher in tall plants (Lang, 1979; Thompson and Holbrook, 2003; Van Bel and Hafke, 2005; Mencuccini and Hölttä, 2010), potentially due to stronger root C sinks associated with a larger belowground biomass. In certain studies, seasonal changes in belowground $\mathrm{C}$ allocation had no effect on the time lag between assimilation and use of assimilates in belowground respiration (Horwath et al., 1994; Högberg et al., 2010), suggesting that phloem path length and structural differences were the main determinants of $\mathrm{C}$ transfer velocity. In contrast, other studies reported considerable variation of the time lag during the growing season in the same trees (Plain et al., 2009; Wingate et al. 2010; Dannoura et al., 2011; Epron et al., 2011; Kuptz et al., 2011a) (Fig. 2). However, the mechanisms behind such variability are still unknown even though seasonal variations of carbon storage and remobilization in the trunk are the most likely mechanisms to affect the transfer of carbon as well as the conveyance of the carbon isotope signal from the canopy in basipetal direction over the growing season (Offermann et al., 2011).

Carbon isotope labeling experiments suggest a longer transport time in gymnosperms compared to angiosperm trees (Kuzyakov and Gavrichkova, 2010), due to structural differences in the phloem. The differences between the two groups can be considerable, despite the heterogeneity in environmental conditions the experiments were conducted at. The observed patterns suggest a separate consideration of gymnosperm and angiosperm tree species in the future. Furthermore, also time lag studies in grasses need to be considered independently, as - in contrast to tree species - time lags may even decrease with increasing plant height as has been shown for Lolium perenne (Kuzyakov and Gavrichkova, 2010).

Recently Vargas et al. (2011) observed multi-temporal correlation between photosynthesis and soil respiration across different ecosystems with time periods between 1 and 16 days. Based on a comprehensive time series analysis of flux data they concluded that multiple biophysical drivers are likely to coexist for the regulation of allocation and transport speed of carbon. Strong correlations both within a 1-day 


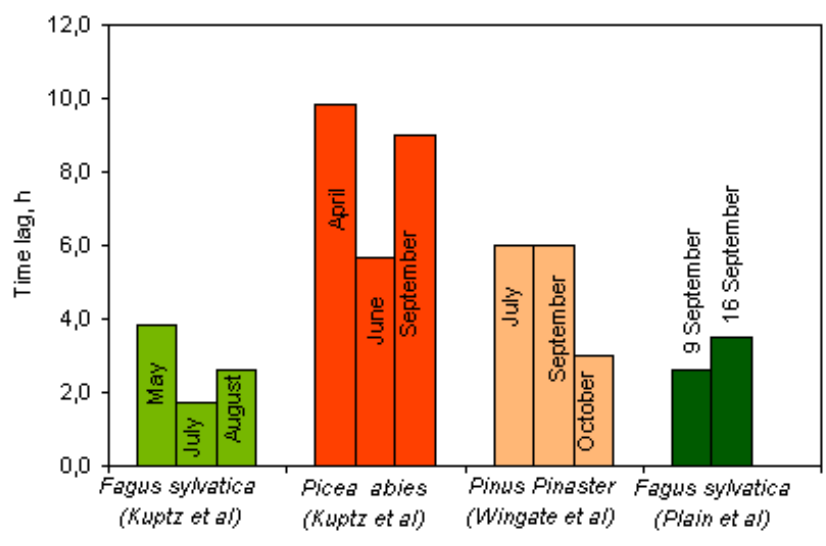

Fig. 2. Seasonal changes in time lag measured by tracing variations in $\delta^{13} \mathrm{C}$ at natural abundance level (Wingate et al., 2010; Kuptz et al., 2011a) or after ${ }^{13} \mathrm{CO}_{2}$ pulse-labeling (Plain et al., 2009) in soil respiration and trunk respiration (at $1 \mathrm{~m}$ height; Kuptz et al., 2011a). Average values were calculated based on monthly ranges reported in Wingate et al. (2010).

period and within periods $>1 \mathrm{~d}$ for forests suggest that the link between assimilation and soil respiration might potentially involve both the propagation of pressure-concentration waves in the phloem and the actual transport of new assimilates from the leaves to belowground tissues. In addition, the correlations with longer time periods might be a result of transient storage and remobilisation of carbon in the plant tissues. Moreover, Heinemeyer et al. (2011) reported differences for particular components of soil respiration (root and mycorrhizal respiration) in their temporal relation and response to gross primary production. The authors assume that carbon storage in roots and/or fungi over days to weeks and later allocation to mycorrhizae might explain the correlation between photosynthesis and mycorrhizal respiration at longer temporal scales.

As a consequence, not only phloem transport but also short-term storage/remobilisation and transfer to rhizosphere biota (see 3.2) have to be considered for the interpretation of the speed of link or degree of coupling (cf. Kayler et al., 2010a) between above- and belowground processes.

\subsection{Carbon transfer to soil biota}

A large fraction of $\mathrm{C}$ fixed by plant photosynthesis is allocated belowground, where $C$ can be: (1) invested into biomass or respired by roots; (2) released as exudates and allocated to soil microorganisms in the rhizosphere (Kuzyakov and Domanski, 2000; Kuzyakov et al., 2000; Walker et al., 2003); or (3) incorporated as litter into soil organic matter that may be respired by heterotrophic soil microorganisms. In this section we focus on pathways (1) and (2). Pathway (3) will be discussed in 4.2 .

Carbon allocated to roots can stimulate exudation, which in turn increases microbial respiration in the rhizosphere
(Kuzyakov and Cheng, 2001; Bowling et al., 2002; Tang et al., 2005). Up to $40 \%$ of photosynthates are exudated by roots and are rapidly respired or invested in biomass by rhizosphere microorganisms (Whipps, 1990; Meharg, 1994; Kuzyakov and Cheng, 2001). The rhizosphere is a narrow zone in the vicinity of the roots characterized by the presence of mycorrhizal fungi and other rhizosphere microorganisms that depend on root exudates as a $\mathrm{C}$ substrate source (Cheng et al., 1996; Jones et al., 2009).

Among rhizosphere microorganisms, mycorrhizal fungi are of great relevance to plant-soil C interactions (Finlay and Söderström, 1992; Stuart et al., 2009; Jones et al., 2009). Several studies indicate that mycorrhizal fungi can use up to $30 \%$ of recent plant photosynthates (Högberg and Högberg, 2002; Johnson et al., 2002; Leake et al., 2006; Heinemeyer et al., 2007; Chapin et al., 2009). It has been shown that plant-derived C flux into (Vandenkoornhuyse et al., 2007) and through arbuscular mycorrhizal hyphae (Staddon et al., 2003; Goldbold et al., 2006) is rapid, i.e. in the range of only a few days. Also for ectomycorrhizal hyphae a fast turnover of freshly assimilated C was found (Godbold et al., 2006), which has been confirmed recently also on the basis of several years of respiration data at high temporal resolution from a deciduous oak forest in southeastern England (Heinemeyer et al., 2011). However, in forests dominated by ectomycorrhiza this linkage seems to vary considerably during seasons and years, suggesting alternative $\mathrm{C}$ sources for ectomycorrhizal metabolism such as litter decomposition (Heinemeyer et al., 2011), but there are too few high temporal resolution flux data available to allow a generalization. The $\mathrm{C}$ turnover in microbial biomass ranges from 7 to 95 days, indicating a slower turnover compared to mycorrhizal fungi (Ocio et al., 1991; Ostle et al., 2003; Kaštovská and Šantrûčková, 2007). The large variability in $\mathrm{C}$ turnover times of soil microorganisms could be associated with a switch between different functional groups of microbes, as e.g. rhizosphere bacteria and mycorrhizal mycelium can be used as $\mathrm{C}$ substrates by other soil microorganisms (Jones et al., 2009).

It has been shown with ${ }^{13} \mathrm{C}$-pulse labeling that also soil macrofauna (e.g. earthworms) may quickly incorporate plant exudates as a $\mathrm{C}$ source in addition to above- and belowground plant litter inputs, probably by incorporating ${ }^{13} \mathrm{C}$-labeled microorganisms (Ostle et al., 2007). Turnover times of $\mathrm{C}$ in earthworms range from 12 to 37 days (Bouche, 1984; Dyckmans et al., 2005). Also collembola (springtails) were found to feed on very recently assimilated $\mathrm{C}$ in contrast to Acari (e.g. mites) and Enchytraeidae (Högberg et al., 2010).

Overall, the $\mathrm{C}$ flux to soil biota in the rhizosphere is large and $\mathrm{C}$ is typically lost from the system within days to months. Environmental conditions imprinted in $\delta^{13} \mathrm{C}$ of photosynthates are thus translated through organisms in the rhizosphere and remain detectable in the autotrophic part of soil respiration $\left(R_{\mathrm{a}}\right.$; see 3.3$)$. 


\subsection{Carbon losses via plant respiration and BVOC emissions}

Respiration of plant tissues and rhizosphere microorganisms constitutes a major $\mathrm{C}$ loss in terrestrial ecosystems and can make up to $80 \%$ of gross primary production (Janssens et al., 2001). Plant respiration is not fuelled by a homogeneous substrate, but by several $\mathrm{C}$ pools with different turnover times and metabolic histories (Schnyder et al., 2003; Ghirardo et al., 2011; Kuptz et al., 2011a). Lehmeier et al. (2008) identified three major $\mathrm{C}$ pools distinguishable by their half-life, which fed dark respiration in shoots and roots of perennial rye grass. Only $43 \%$ of respiration was directly driven by current photosynthates, thus pointing to the importance of short-term storage pools with half-lives of a few hours to more than a day. This finding is in agreement with observations made by Nogués et al. (2004) for French bean, showing that the leaf respiratory substrate is a mixture in which current photosynthates are not the main components. Changes in the N supply (Lehmeier et al., 2010), but presumably also in other environmental conditions, can change the mean residence time of the respiratory substrate pool mainly due to different contributions from storage. In summary, plant respiratory $\mathrm{CO}_{2}$ losses are largely, but not exclusively fuelled by recently assimilated $\mathrm{C}$. Temporal changes in substrate use (e.g. Hymus et al., 2005; Nogués et al., 2006) and post-carboxylation isotope fractionation in leaves and heterotrophic tissues can partially uncouple the isotope composition of respired $\mathrm{CO}_{2}$ from assimilates (see also 2.2), and imprint valuable information in its $\delta^{13} \mathrm{C}$. However, as measurements in tall stature plants are technically challenging, data on plant respiration and its isotopic composition from field studies, especially from forests, are scarce.

Also the emission of biogenic volatile organic compounds (BVOC) can constitute a considerable loss of $\mathrm{C}$ from vegetation in the range of a few percent of the current net assimilation rate under non-stress conditions, but can reach or even exceed net assimilation rates under stress conditions, such as drought, and continue even when net assimilation has ceased (e.g., Brüggemann and Schnitzler, 2002), using alternative carbon sources like xylem-transported sugars and breakdown of starch (Loreto and Schnitzler, 2010). However, BVOC emission rates differ strongly among plant species and genera, and thus only play a role for the $\mathrm{C}$ budget of particular species, e.g. for isoprene-emitting poplar, oak and willow species (Sharkey et al., 2008). In view of the predicted future increases in temperature and drought periods, BVOC might play an increasing role in determining the $\mathrm{C}$ budget of ecosystems that are dominated by BVOC-emitting plant species, although elevated atmospheric $\mathrm{CO}_{2}$ has been found to counteract temperature effects on BVOC emission (cf. Peñuelas and Staudt, 2010, for a review).

The carbon isotopic signature of isoprene has been found moderately ${ }^{13} \mathrm{C}$-depleted by 2 to $3 \%$ as compared to recently fixed carbon (Sharkey et al., 1991; Rudolph et al., 2003) or stronger depleted by 4 to $11 \%$ (Affek and Yakir, 2003). The reason for this observation might be fractionation along the isoprene biosynthesis pathway, but also the fact that isoprene biosynthesis is, like plant respiration, not solely fuelled from recent assimilates, but also from alternative sources, such as xylem-transported sugars (Kreuzwieser et al., 2002; Ghirardo et al., 2011), which might be ${ }^{13} \mathrm{C}$-depleted as compared to recent assimilates at the time of their use in isoprene biosynthesis. Once released to the atmosphere, isoprene does not preserve its original ${ }^{13} \mathrm{C}$ signature, as it is highly reactive and undergoes fast oxidation reactions with ozone and hydroxyl radicals, leading to a ${ }^{13} \mathrm{C}$-enrichment in the remaining isoprene (Iannone et al., 2010). This has to be considered when interpreting atmospheric isoprene carbon isotope signals.

Most other BVOC are also characterized by ${ }^{13} \mathrm{C}$ signatures close to that of the leaf material they were emitted from (Goldstein and Shaw, 2003). The only major exception are methyl halides, which are derived in plants from the methoxy groups of pectin, which themselves are already significantly ${ }^{13} \mathrm{C}$-depleted as compared to the bulk leaf material (Keppler et al., 2004).

\subsection{Temporal $\mathrm{C}$ allocation patterns}

Also the $\delta^{13} \mathrm{C}$ of soil $\mathrm{CO}_{2}$ efflux has been shown to exhibit diel variations (e.g. Kodama et al., 2008; Bahn et al., 2009; but see Betson et al., 2007). However, from correlation-based flux studies it is not consistently clear to which extent they are temperature- (and moisture-) independent and thus possibly related to rapid allocation of $\mathrm{C}$ from recent photosynthesis to respiration (Tang et al., 2005; Bahn et al., 2008; Subke and Bahn, 2010; Vargas et al., 2010; Philipps et al., 2011). It is also not clear to which extent these diel variations of $\delta^{13} \mathrm{C}$ of soil $\mathrm{CO}_{2}$ efflux reflect the number of processes potentially involved, including changes in vapor pressure deficit that affect photosynthetic discrimination against ${ }^{13} \mathrm{C}$ (Brugnoli et al., 1988; Farquhar et al., 1989; see 2.1), changes in respiratory $\mathrm{C}$ isotope fractionation as demonstrated for $\mathrm{CO}_{2}$ respired by leaves (Hymus et al., 2005) as well as trunks (Kodama et al., 2008), diurnal changes in respiratory carbon source (Tcherkez et al., 2004; Gessler et al., 2007; Bahn et al., 2009; Barthel et al. 2011) and diffusion processes (Moyes et al., 2010). For a detailed mechanistic analysis of the origin of diel variations in the $\delta^{13} \mathrm{C}$ see Werner and Gessler (2011).

Initial growth and respiration are supplied from storage $\mathrm{C}$ in seeds in both annual and perennial plants (Bathellier et al., 2008). Carbon isotope ratios of young plants will thus be dominated by storage compounds (e.g. ${ }^{13} \mathrm{C}$-depleted lipids or ${ }^{13} \mathrm{C}$-enriched carbohydrates; see 2.2). Similarly, leaf growth in deciduous trees relies on stored C (mainly starch) during the first phase of leaf development (Lacointe et al., 2004; Kagawa et al., 2006a; Asaeda et al., 2008), which in some species can be rather short (Keel and Schädel, 2010). 
Damesin and Lelarge (2003) have documented the switch from ${ }^{13} \mathrm{C}$-enriched starch to more ${ }^{13} \mathrm{C}$-depleted assimilates for young beech leaves. In contrast, new foliage of evergreen species is typically considered to be made almost entirely of recent assimilates (Hansen and Beck, 1994; Cerasoli et al., 2004).

Early radial growth of stems is often supplied by reserves as well (Helle and Schleser, 2004; Kagawa et al., 2006b; Skomarkova et al., 2006). However, distinct differences in the use of recent vs. stored $\mathrm{C}$ for radial growth have been documented for deciduous trees, with some species incorporating negligible amounts of reserves (Keel et al., 2006). During summer, photosynthates are allocated mainly above ground (Mordacq et al., 1986; Olsrud and Christensen, 2004), supplying shoot elongation (Schier, 1970; Hansen and Beck, 1994), radial growth (Gordon and Larson, 1968), further foliage development (Dickson et al., 2000; Lamade et al., 2009) and flowering and fruiting (Mor and Halevy, 1979; Hoch and Keel, 2006). Possibly as a result of rapid mixing between old and new C (Keel et al., 2007) there is a carryover of stores for wood growth in most species (Kagawa et al., 2006b; Keel et al., 2006; von Felten et al., 2007; Palacio et al, 2011), which may impair the use of isotope tree-ring data as proxy for environmental processes.

Changes in the relative contributions of different $\mathrm{C}$ sources throughout phenological plant development entail remarkable seasonal variations in the $\delta^{13} \mathrm{C}$ of different plant organs (Damesin and Lelarge, 2003; Helle and Schleser, 2004). Such variations may hinder the interpretation of $\delta^{13} \mathrm{C}$ in plants as indicator for environmental conditions (CavenderBares and Bazzaz, 2000; Helle and Schleser, 2004). The contribution of new $\mathrm{C}$ to foliage production is highly variable in deciduous species (Keel et al., 2006), but on average close to the c. $70 \%$ reported for evergreen Pinus uncinata trees (von Felten et al., 2007). The amount of new $\mathrm{C}$ used for stem growth ranges from $35 \%$ (Quercus petraea saplings; Palacio et al., 2011) to $71 \%$ (average of 5 deciduous tree species, Keel et al., 2006). Within deciduous plants, diffuse porous species allocate significantly higher amounts of new $\mathrm{C}$ to wood than ring-porous species $(52 \%$ vs. $35 \%$, respectively; Palacio et al., 2011). Thus, differences between evergreen and deciduous species may be smaller than initially thought and, in some cases, overridden by inter-species variability.

Carbon allocation patterns are known to vary not only throughout the life cycle of plants but also with the age of the different plant organs (Kozlowski, 1992). These changes are particularly relevant for long-lived perennial species. In general, older plants tend to decrease allocation belowground, and to increase allocation to maintenance (increased standing biomass and respiration) (Kozlowski, 1971), storage pools (Lusk and Piper, 2007; Genet et al., 2010), defense mechanisms (Boege, 2005; Boege and Marquis, 2005) and reproduction (Genet et al., 2010). Changes in C allocation to plant organs entail quantitative and qualitative differences in their $\mathrm{C}$ composition with age. Consequently, the $\mathrm{C}$ isotope composition of plant respiratory $\mathrm{CO}_{2}$ (Maunoury et al., 2007; Kuptz et al., 2011b) or of bulk material (Helle and Schleser, 2004; Skomarkova et al., 2006; Salmon et al., 2011) may change with season and ontogeny. For example, leaves of adult plants tend to be enriched in ${ }^{13} \mathrm{C}$, showing higher $\delta^{13} \mathrm{C}$ than leaves of young plants (Donovan and Ehleringer, 1994; Cavender-Bares and Bazzaz, 2000; Fessenden and Ehleringer, 2002). Information on the age-related variations of $\delta^{13} \mathrm{C}$ in the different organs of plants (including not only leaves but also roots or stems for which data are mostly absent) is crucial for scaling $\delta^{13} \mathrm{C}$ results on young plants to mature individuals.

Belowground plant parts are supplied by both recent photosynthates and C reserves (Joslin et al., 2006; Carbon and Trumbore, 2007). Recent investigations estimated that up to $55 \%$ of fine root $\mathrm{C}$ comes from storage, although such stored $\mathrm{C}$ seems of young age (approx. 0.4 years) (Gaudinski et al., 2009). Belowground allocation of newly fixed $C$ increases dramatically towards the end of the growing season (Smith and Paul, 1988; Stewart and Metherell, 1999, Högberg et al., 2010; Epron et al., 2011), competing with storage accumulation in aboveground parts for winter dormancy and frost hardiness (Hansen and Beck, 1990; Skomarkova et al., 2006; Kuptz et al., 2011a). In evergreen species, a second maximum of belowground allocation of recent $\mathrm{C}$ is often observed in early spring, shortly before bud break (Shiroya et al., 1966; Ziemer, 1971). During winter, deciduous species maintain their living tissue mainly from reserve pools (Dickson, 1989; Maunoury et al., 2007), whereas evergreen trees may produce new substrate for respiration (mainly maintenance respiration) by active photosynthesis during warmer periods within the cold season (Hansen et al., 1996; Hu et al., 2010; Kuptz et al., 2011b). Similar to the cold season, summer drought might induce a seasonal allocation pattern with regularly occurring favorable and unfavorable growth conditions, leading to seasonal changes in growth and in the contribution of growth and maintenance respiration to $R_{\mathrm{a}}$. Such phases are likely to be associated with variations in $\delta^{13} \mathrm{C}$ of plant respired $\mathrm{CO}_{2}$. If assimilate supply decreases, ${ }^{13} \mathrm{C}$ enriched stores can serve as substrates for respiration leading to increases in $\delta^{13} \mathrm{C}$ of released $\mathrm{CO}_{2}$.

Relatively little is known about interannual variations compared to the wealth of studies on seasonal changes in $\mathrm{C}$ allocation. Carbon allocation to radial stem growth is typically correlated with climatic conditions such as precipitation and air temperature, a relationship used for climate reconstructions by dendrochronologists. Interestingly, Rocha et al. (2006) found no correlation between gross ecosystem production (a measure for photosynthesis at the stand scale) with tree ring width, suggesting that radial growth is not directly related to the availability of recent $\mathrm{C}$, but also depends on the amount of carbohydrate stored.

Although significant advances have been made in recent years to characterize the use of stored $\mathrm{C}$ in plants 
(represented by "Starch" in Fig. 4), there are still important knowledge gaps to fill. For example, the relationship between the age of plant stores and remobilization is still not fully understood, raising the question of how much of the $\mathrm{C}$ stored by plants can actually be remobilized (Millard et al., 2007), and how long these stores can be remobilized before they are ultimately sequestered in plant tissues or lost as $\mathrm{CO}_{2}$ or BVOC. It is also not known how stores are mobilized in relation to the time (phenology and age) they were built up (but see initial results by Lacointe et al., 1993), or how these processes are affected by environmental stress and disturbance. These key questions have to be answered before the role of plants in ecosystem $\mathrm{C}$ cycling can be fully understood.

\subsection{Bi-directional $\mathrm{C}$ transport processes}

Efflux of $\mathrm{CO}_{2}$ from the soil to the atmosphere is not the only escape way of carbon out of the soil. It has been shown with isotopically labeled $\mathrm{CO}_{2}$ that roots can take up $\mathrm{CO}_{2}$ and deliver it to aboveground parts of the plant via the transpiration stream (Ford et al., 2007; Moore et al., 2008). It is known since many years that $\mathrm{CO}_{2}$ concentrations in the xylem sap of plants can be up to three orders of magnitude higher than in the atmosphere (Eklund, 1990; Hari et al., 1991; Levy et al., 1999; Teskey et al., 2008 and citations therein). In addition to root uptake of soil $\mathrm{CO}_{2}$, root respiration adds $\mathrm{CO}_{2}$ to the xylem water, followed by stem respiration, i.e. in the inner bark (consisting of the periderm and the phloem), in the cambium and in the ray cells of the xylem (Teskey et al., 2008). As especially the cambium, but also the cell walls of the xylem are strong diffusion barriers, very high $\mathrm{CO}_{2}$ partial pressure $\left(p \mathrm{CO}_{2}\right)$ can build up inside the stem.

The high xylem $p \mathrm{CO}_{2}$ has significant effects on stem, branch and leaf $\mathrm{CO}_{2}$ exchange. Martin et al. (1994) found temperature-independent fluctuations in stem $\mathrm{CO}_{2}$ efflux in loblolly pine (Pinus taeda L.) seedlings, with flux rates being $6.7 \%$ lower during periods of high transpiration associated with high temperatures, as compared with periods of low transpiration. They could identify transport of respiratory $\mathrm{CO}_{2}$ in and diffusive loss from the transpiration stream as the most likely cause of this unexpected observation. Levy et al. (1999) calculated a contribution of xylem-transported $\mathrm{CO}_{2}$ to leaf photosynthetic rates of 0.5 to $7.1 \%$, and a contribution of up to $12 \%$ to apparent stem respiration rates. Teskey and McGuire $(2002$, 2005) observed a linear relationship between stem $\mathrm{CO}_{2}$ efflux and xylem sap $\mathrm{CO}_{2}$ concentrations. They could evoke rapid and reversible changes of stem $\mathrm{CO}_{2}$ efflux by manipulating xylem sap $\mathrm{CO}_{2}$ concentrations, explaining up to $77 \%$ of the stem efflux variation. The negative relationship of xylem sap $p \mathrm{CO}_{2}$ with xylem sap velocities or volume flow presents an explanation for the frequently observed midday depression of stem $\mathrm{CO}_{2}$ efflux, when xylem sap flow is highest and, hence, xylem $\mathrm{CO}_{2}$ concentration is lowest (Teskey and McGuire, 2002; Aubrey and Teskey, 2009). Overall, it has to be acknowledged that xylem-mediated $\mathrm{CO}_{2}$ transport from the soil to the atmosphere can be substantial, in some cases equaling soil $\mathrm{CO}_{2}$ efflux (Aubrey and Teskey, 2009).

By far not all of the xylem $\mathrm{CO}_{2}$, be it soil-, root- or stemderived, is released via stem efflux. It was shown already a long time ago that not only leaves, but also woody tissue can assimilate $\mathrm{CO}_{2}$ via photosynthesis (e.g., Wiebe, 1975; Foote and Schaedle, 1976; Pfanz et al., 2002). Albeit this corticular photosynthesis usually does not lead to a net $\mathrm{CO}_{2}$ uptake, it can compensate for most of the respiratory loss during the light period (Foote and Schaedle, 1976; Pfanz et al., 2002; Cernusak and Marshall, 2000; Wittmann et al., 2006). Given the high xylem $p \mathrm{CO}_{2}$, it is likely that most of the $\mathrm{CO}_{2}$ fixed by the woody tissue is derived from the stem-internal $\mathrm{CO}_{2}$ pool, as could be shown in a ${ }^{13} \mathrm{CO}_{2}$ labeling study with sycamore (McGuire et al., 2009). However, as the transpiration stream ends in the leaves of a plant, the remaining $\mathrm{CO}_{2}$ will be subject to photosynthetic fixation here, which was demonstrated in a labeling study with a $1 \mathrm{mM}{ }^{14} \mathrm{C}$-bicarbonate solution fed to excised leaves of Populus deltoides (Stringer and Kimmerer, 1993). If soil $\mathrm{CO}_{2}$ taken up by the roots is fixed during photosynthesis, this will have implications for the carbon isotopic signature of photosynthates due to the much lower $\delta^{13} \mathrm{C}$ of the soil-derived $\mathrm{CO}_{2}$, depending on the amount of $\mathrm{CO}_{2}$ transported with the transpiration stream.

Beside phloem transport, large amounts of $\mathrm{C}$ can also be transported via the transpiration stream, even in periods when leaves are fully developed and re-mobilization of $\mathrm{C}$ from storage pools is unlikely to occur. In pedunculate oak (Quercus robur L.) saplings, Heizmann et al. (2001) found a contribution of xylem-transported carbohydrates, mainly sucrose, glucose and fructose, to the total $\mathrm{C}$ budget of leaves of up to $91 \%$, with the highest values occurring during midday depression of photosynthesis at high temperature. In grey poplar, xylem transport of carbohydrates contributed $9 \%$ to $28 \%$ to the total $\mathrm{C}$ delivered to the leaves (Mayrhofer et al., 2004). This xylem-transported $\mathrm{C}$ can form a major constituent of leaf $\mathrm{C}$ metabolism, as was shown in labeling experiments with ${ }^{13} \mathrm{C}$-glucose in pedunculate oak (Kreuzwieser et al., 2002) and in grey poplar (Schnitzler et al., 2004; Ghirardo et al., 2011). The cycling of $C$ within the plant through the phloem down to the roots and back to the aboveground parts of the plants via the xylem makes the supply of carbohydrates to heterotrophic tissues independent of short-term fluctuations of photosynthetic performance of the plants, as hypothesized by Heizmann et al. (2001), but also leads to a dampening of photosynthetic carbon isotope signals sent from the leaves down to the roots.

\subsection{Sensitivity of $\mathrm{C}$ allocation to environmental stress}

The general responses of plant ecophysiological processes to environmental stress (e.g. resource limitations in light, water or nutrients) have been well known for many years 
(Larcher, 2003). Ecophysiological responses often involve changes at different organizational levels, ranging from cellular mechanisms to whole plant carbon-water or carbonnutrient relations to sustain plant performance and plant fitness under stress. Stable carbon isotopes have been shown to be sensitive indicators of leaf stress responses involving stomatal regulations, changes in mesophyll conductance and (photo)respiration (Farquhar et al., 1989; Dawson and Siegwolf, 2007, and references therein). For example, leaf carbon discrimination was shown to increase under light stress for $\mathrm{C}_{3}$ (Brugnoli and Farquhuar, 2000) and $\mathrm{C}_{4}$ plants (Buchmann et al., 1996), but decrease under water limitations (Dawson et al., 2002).

Recently, it was demonstrated that drought stress not only reduced $\mathrm{C}$ assimilation but often also increased the mean residence time of recently assimilated $\mathrm{C}$ in leaf biomass; furthermore, the $\mathrm{C}$ transfer velocity was reduced in saplings and the trunk of some tree species, leading to a reduced coupling between canopy photosynthesis and belowground processes under water stress (Ruehr et al., 2009; Barthel et al. 2011; Dannoura et al., 2011). Similarly, shading has been shown to reduce the speed of link between photosynthesis and soil respiration in grassland (Bahn et al., 2009). Mechanisms underlying these short-term responses to stress are possibly related to source-sink relationships, as at low photosynthetic rates a decrease of phloem loading at the collection phloem end will lower the pressure gradient and hence decrease the downward transport rates (Lee, 1981). Furthermore, soil moisture influences the quantity of water supplied by the xylem to the collection phloem, affecting the turgor pressure differences between two phloem ends. Potentially, all environmental factors which affect photosynthesis (vapor pressure deficit, radiation, $\mathrm{CO}_{2}$ concentration, etc.) might have similar consequences. However, more studies, including also compound-specific carbon isotope analyses, are needed to further elucidate the biochemical and physiological mechanisms responsible for these patterns.

\section{Belowground $\mathrm{C}$ turnover}

Stable isotopes have proven to be a technique to address the complex carbon transformations in the soil (Kuzyakov et al., 2000; Bowling et al., 2008; Paterson et al., 2009; Kayler et al., 2010a). Here, we extend the view of isotopes in belowground research beyond methodology, but limit the scope of our discussion of carbon isotopes to the investigation of plant-soil interactions with a specific emphasis on plant direct and indirect controls on rhizosphere respiration, microbial metabolism, organo-mineral interactions, dynamic soil carbon pools, and microbial markers.

\subsection{Rhizosphere respiration}

Soil $\mathrm{CO}_{2}$ efflux is dominated by two major sources of soil respiration: an autotrophic component $\left(R_{\mathrm{a}}\right.$, roots, mycorrhizal fungi and other root-associated microbes dependent on recent $\mathrm{C}$ photosynthates) and a heterotrophic component ( $R_{\mathrm{h}}$, organisms decomposing soil organic matter). A large array of methods for partitioning $R_{\mathrm{a}}$ and $R_{\mathrm{h}}$ exists, the advantages and disadvantages of which have been extensively reviewed elsewhere (Hanson et al., 2000; Kuzyakov, 2006; Subke et al., 2006; Trumbore, 2006). On average, $R_{\mathrm{a}}$ and $R_{\mathrm{h}}$ contribute equal amounts to total soil respiration, ranging from 10 to $90 \%$ in single studies (Hanson et al., 2000), with the contribution of $R_{\mathrm{a}}$ increasing with annual soil $\mathrm{CO}_{2}$ efflux (Subke et al., 2006; Bond-Lamberty and Thomson, 2010).

While many experiments suggest that $R_{\mathrm{a}}$ strongly depends on recent photosynthates as indicated by rapid and pronounced declines in soil respiration after clipping, shading or phloem girdling (Craine et al., 1999; Högberg et al., 2001; Wan and Luo, 2003), other studies have reported only minor effects (Hibbard et al., 2005; Zhou et al., 2007; Bahn et al., 2009; Bond-Lamberty and Thomson, 2010). These latter studies indicate that root $\mathrm{C}$ stores might serve as respiratory substrates for $R_{\mathrm{a}}$ and allow to maintain respiration rates at least temporarily (Bahn et al., 2006). This is supported by radiocarbon analysis of root respired $\mathrm{CO}_{2}$, which showed that roots partly respire older C (Cisneros-Dozal et al., 2006; Czimczik et al., 2006; Schuur and Trumbore, 2006). In contrast, respiration by microbes in the rhizosphere is not buffered by carbohydrate reserves and may decline more rapidly after interruption of assimilate supply (Bahn et al., 2006).

Dramatic increases in $R_{\mathrm{a}}$ have been found in strongly seasonal ecosystems at high latitudes in late as opposed to early summer (Högberg et al., 2010), indicating that $R_{\mathrm{a}}$ is dependent on plant phenology and/or the season. Higher $R_{\mathrm{a}}$ is likely dominated by increased growth respiration, while maintenance respiration is assumed to undergo less seasonal change (Wieser and Bahn, 2004). Although higher temperatures in late summer undoubtedly play a role in the observed increase in $R_{\mathrm{a}}$, the occurrence of hysteresis, expressed as different respiration rates measured at the same soil temperatures in different seasons (Högberg et al., 2009), suggests that additional factors, such as phenology, control $R_{\mathrm{a}}$. At shorter time scales, changes in physical transport processes of $\mathrm{CO}_{2}$ and heat hold an alternative explanation for the occurrence of hysteresis (Subke and Bahn, 2010; Phillips et al., 2011).

Nutrient availability can also exert a strong control on $R_{\mathrm{a}}$. In N-poor systems, addition of $\mathrm{N}$ fertilizer reduces $R_{\mathrm{a}}$ (Högberg et al., 2010), associated with an increase in aboveground C allocation (Olsson et al., 2005). Responses in total soil respiration rates have been found to increase, decrease or remain unaltered as reviewed by Janssens et al. (2010). The discrepancy in these results may reflect the combined responses of plants and soil to $\mathrm{N}$ fertilization. 
Many studies show a pronounced effect of soil moisture on $R_{\mathrm{a}}$ relative to total soil respiration. During a dry summer, the amount of recent $\mathrm{C}$ respired decreased in an evergreen forest (Andrews et al., 1999), possibly as a result of a reduction in C supply from above ground. Similarly, Ruehr et al. (2009) found less labeled $C$ respired in drought experiments (see also 3.6). In contrast, an increase in the fraction of recent $\mathrm{C}$ was measured in soil $\mathrm{CO}_{2}$ during an exceptionally dry summer in a temperate deciduous forest (Keel et al., 2006). These different results might be explained by interacting effects of soil moisture and temperature on C supply for respiration (Davidson et al., 2006), different contributions of the individual component fluxes to total soil respiration, or changes in $\mathrm{CO}_{2}$ transport rates in the soil (Phillips et al., 2011).

Little is known about the biotic and abiotic factors that regulate rhizosphere respiration despite its importance for the terrestrial C cycle (Högberg and Read, 2006; Chapin et al., 2009). Carbone et al. (2007) showed that ${ }^{14} \mathrm{C}$-labeled assimilates respired by rhizosphere microorganisms had a mean residence time of 15 days, but 30 days after the labeling, the signal was still detectable in soil respiration. Moyano et al. (2008) suggested that factors controlling mycorrhizal respiration are similar to those that control root respiration. However, recent studies indicate that mycorrhizal respiration may be less sensitive to temperature than root respiration (Heinemeyer et al., 2007; Moyano et al., 2007; Nottingham et al., 2010).

Overall, the autotrophic component of soil respiration is closely coupled to assimilate supply and is sensitive to factors that control $\mathrm{C}$ uptake (e.g. phenology, $\mathrm{N}$ availability, and shading) and $\mathrm{C}$ allocation patterns. Root respiration can also be supplied by stored $\mathrm{C}$, if assimilate supply is interrupted. How C stores contribute to $R_{\mathrm{a}}$ under normal conditions will affect the plant-soil respiratory $\delta^{13} \mathrm{C}$ linkage. It can be concluded that the link should be tightest during periods of high $\mathrm{C}$ supply and in plant species with small $\mathrm{C}$ stores.

Heterotrophic soil respiration $\left(R_{\mathrm{h}}\right)$ is mainly affected by soil temperature and moisture. However, recent studies have shown the importance of soil $\mathrm{C}$ availability as a driver of heterotrophic respiration (Vance and Chapin, 2001; Trueman and Gonzalez-Meler, 2005; Scott-Denton et al., 2006). There is evidence that fresh $\mathrm{C}$ input into soil can increase, decrease or have little or no effect on $R_{\mathrm{h}}$ (Kuzyakov et al., 2000; Fontaine et al., 2007). This variability of the $R_{\mathrm{h}}$ response to soil $\mathrm{C}$ availability may arise in part because soil organic matter (SOM) consists of several functional $\mathrm{C}$ pools with different levels of protection and recalcitrance (Six and Jastrow, 2002). Furthermore, the diversity found in soil microbial communities may result in different preferential usage of soil organic carbon (SOC) sources contributing to the difficulty in correlating changes in $R_{\mathrm{h}}$ in response to soil C availability. Details on SOM turnover and isotopic discrimination associated with it will be given in the following chapters.

\subsection{Patterns of SOM $\delta^{13} \mathrm{C}$ isotopic enrichment with soil depth}

Bulk SOM is a large-scale representation of belowground biogeochemistry in that isotopic values of SOM integrate processes over a large scale of both space and time. Across many ecosystems SOM becomes increasingly ${ }^{13} \mathrm{C}$-enriched (1 to $3 \%$ ) with depth. Ehleringer et al. (2000) offered four hypotheses to describe this pattern: (1) the Suess effect i.e. the decrease in $\delta^{13} \mathrm{C}$ of atmospheric $\mathrm{CO}_{2}$ due to the admixture of anthropogenic, isotopically depleted $\mathrm{CO}_{2}$ - which accounts for about $1 \%$ o from the litter to about $6 \mathrm{~cm}$ depth (Boström et al., 2007); (2) microbial fractionation; (3) preferential microbial decomposition of litter and SOM; and (4) soil carbon mixing. Wynn et al. (2005) included microbes as precursors of SOM and variable mobility and sorption of DOC with variable isotopic values. Identification of which of these hypotheses correctly explains the variation of $\delta^{13} \mathrm{C}$ with depth will potentially reveal important biogeochemical mechanisms of carbon flow that are common to all ecosystems. Yet, part of the difficulty in validating these different hypotheses is the relatively small change of the vast pool of SOM over a short period of time. However, recent experiments have been carried out that provide direct and indirect evidence of the importance of each process in describing patterns of SOM enrichment with depth.

Studies using the Rayleigh distillation equation (Fry, 2008) have shown some success towards explaining the patterns in SOM $\delta^{13} \mathrm{C}$ enrichment (Accoe et al., 2002; Wynn et al., 2005, 2006; Diochon and Kellman, 2008). In this case, the Rayleigh distillation equation describes kinetic isotope fractionation (i.e. unidirectional reactions) in an open substrate reservoir and a product (Wynn et al., 2006). The Rayleigh distillation equation from Wynn et al. (2006) is a first order reaction model described by the isotopic

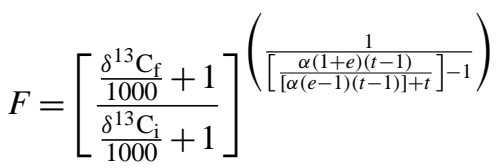

signature of SOM $\left(\delta^{13} \mathrm{C}_{\mathrm{f}}\right)$, the isotopic composition of biomass input $\left(\delta^{13} \mathrm{C}_{\mathrm{i}}\right)$, the fractionation factor between SOM and respired $\mathrm{CO}_{2}(\alpha)$, and the $\mathrm{SOM}$ fraction remaining. The Rayleigh distillation equation is a function of fractionation resulting from two processes: microbial metabolism or differential sorption of organic components to mineral surfaces. From these studies (Wynn et al., 2005, 2006; Diochon and Kellman, 2008), it is apparent that the pattern of ${ }^{13} \mathrm{C}$ enrichment of SOM with depth is dependent on the fractionation parameter in the Rayleigh model which is limited in the ability to distinguish between the two fractionation mechanisms.

\subsection{Fractionation due to microbial metabolism}

The carbon metabolism of microbes is crucial to understanding autotrophic and heterotrophic contributions of soil 


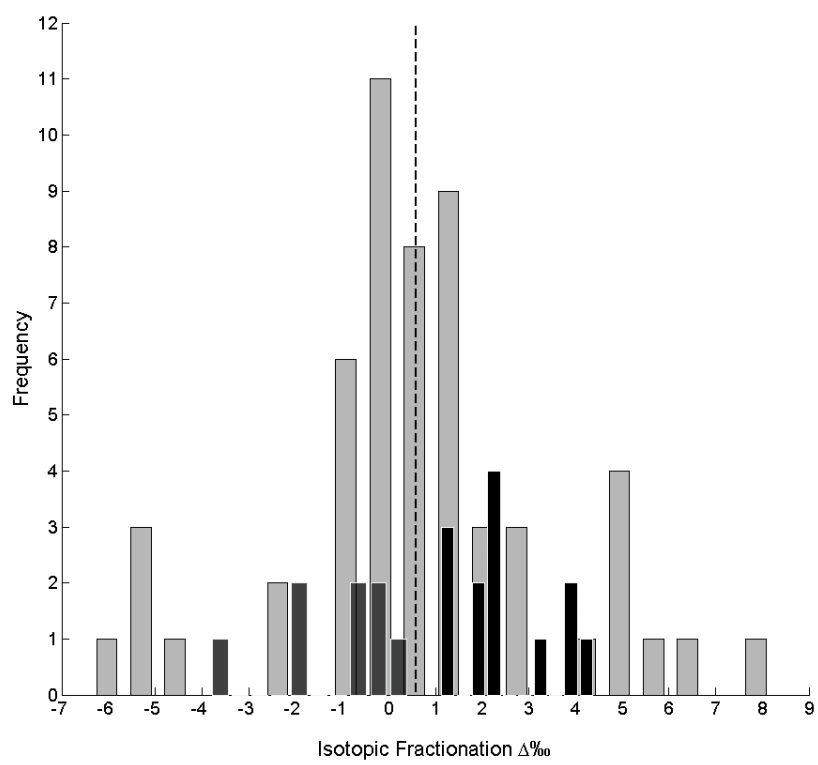

Fig. 3. Estimates of apparent fractionation associated with soil microbial respiration determined by different experimental approaches (grey bars: from $\mathrm{C}_{3}$ plants; dark grey bars: Rayleigh distillation methods, black bars: $\mathrm{C}_{4}$ plants). The dashed line is the mean of all estimates. Data sources: Werth and Kuzyakov, 2010; Wynn et al., 2005, 2006; Diochon and Kellman, 2008.

respiration. Thus, if isotopes are to be an effective tool to estimate heterotrophic respiration then we need to quantify the fractionation by microbes to back-calculate the isotopic source that is respired (i.e. old vs. new carbon sources or, more precisely, soil organic matter or root exudates). Microbial ${ }^{13} \mathrm{C}$ fractionation is a challenge to measure, but is nonetheless very important to accurately quantify because it can confound the interpretation of results from experiments using ${ }^{13} \mathrm{C}$ pulse labeling or natural ${ }^{13} \mathrm{C}$ abundance. Fractionation is commonly calculated by quantifying the difference between the isotopic signature of microbial biomass and the isotopic signature of the substrate (i.e. SOM, DOC, culture) and products (i.e. $\mathrm{CO}_{2}$ ) (Fry, 2008). There is a wide range of estimates of fractionation by microbes from studies implementing this approach (Fig. 3). However, Lerch et al. (2011) found fractionation to vary over time when calculated in this manner, and while changes in substrate could account for this pattern it is also likely that the active microbial community is changing. Fast changes in microbial composition have been documented after addition of labile substrate (Cleveland et al., 2007), rapidly changing environmental conditions (Gordon et al., 2008), and other environmental stresses (Schimel et al., 2007). The question arises whether this variation in microbial fractionation is real, or whether estimates of fractionation are possibly confounded by different soil substrates or microbial community composition.

A recent review of belowground fractionation (Werth and Kuzyakov, 2010) suggests that fractionation occurs during both microbial uptake and respiration of carbon. The specific processes associated with each are: (1) uptake, associated with enzymatic breakdown of organic matter and transport of monomers into cell walls; and (2) respiration associated with kinetic ${ }^{13} \mathrm{C}$ fractionation. The authors listed variation in the availability and molecular composition of substrates as a possible fractionation mechanism during uptake, but this is better defined by mixing processes and microbial community dynamics. Mixing, because soil organic matter is a mixture of chemical compounds, representing different stages of decomposition and availability, which is dependent on the activity and the composition of the microbial community present (see below). They also suggested that preferential substrate utilization of easily degraded compounds results in fractionation during respiration, which may well result in differences between the ${ }^{13} \mathrm{C}$ signature of substrate and products (microbial biomass, remaining $\mathrm{SOC}$ or $\mathrm{CO}_{2}$ ). However, the mechanisms behind this are not well defined or understood. Perhaps, microbial substrate selectivity is a function of the enzymes available to break down substrate.

As discussed above, organic matter sources that contain multiple carbon moieties confound accurate estimates of fractionation resulting from microbial metabolism. Experiments that observe biochemical pathways within microbes by utilizing a controlled substrate provide a more precise picture of fractionation. Hayes (2001) compiled a comprehensive review of carbon fractionation in biosynthetic processes. In this review, he shows how fractionation occurring in chemical reactions, pathways and branch points within a cell results in the isotopic composition of carbohydrates, amino acids, nucleic acids, and lipids among different organisms. The often cited study on Escherichia coli by Blair et al. (1985) documented fractionation between the acetate and fatty acid synthesis, most likely with the conversion of acetyl phosphate to acetyl-CoA as regulated by phosphotransacetylase. Building on previous studies on plants (Ghashghaie et al., 2003), two mechanisms of fractionation that lead to $\delta^{13} \mathrm{C}$ values of $\mathrm{CO}_{2}$ that are different from the initial substrate or microbial biomass were hypothesized: (1) the non-uniform distribution of ${ }^{13} \mathrm{C}$ within hexose molecules (or other substrate) (Hobbie and Werner, 2004), which leads to ${ }^{13} \mathrm{C}$ enriched $\mathrm{CO}_{2}$; and (2) fractionation during the pyruvate dehydrogenase reaction (Blair et al., 1985), which leads to ${ }^{13} \mathrm{C}$ depletion of $\mathrm{CO}_{2}$.

Microbial metabolism type will also affect the magnitude and direction of isotopic fractionation. Differences in biosynthetic pathways result in a diverse isotopic composition of extracted soil microbial biomass. For example, oxygen availability determines in part the level of anaerobic versus aerobic respiration by microbes, which in turn affects the isotopic composition of microbial biomass and fatty acids (Teece et al., 1999; Cifuentes and Salata, 2001). Carbon fixation by heterotrophs, which is estimated to be $4 \%$ to $7 \%$ of net microbial respiration (Miltner et al., 2004, 2005), is another pathway that leads to different isotopic composition 


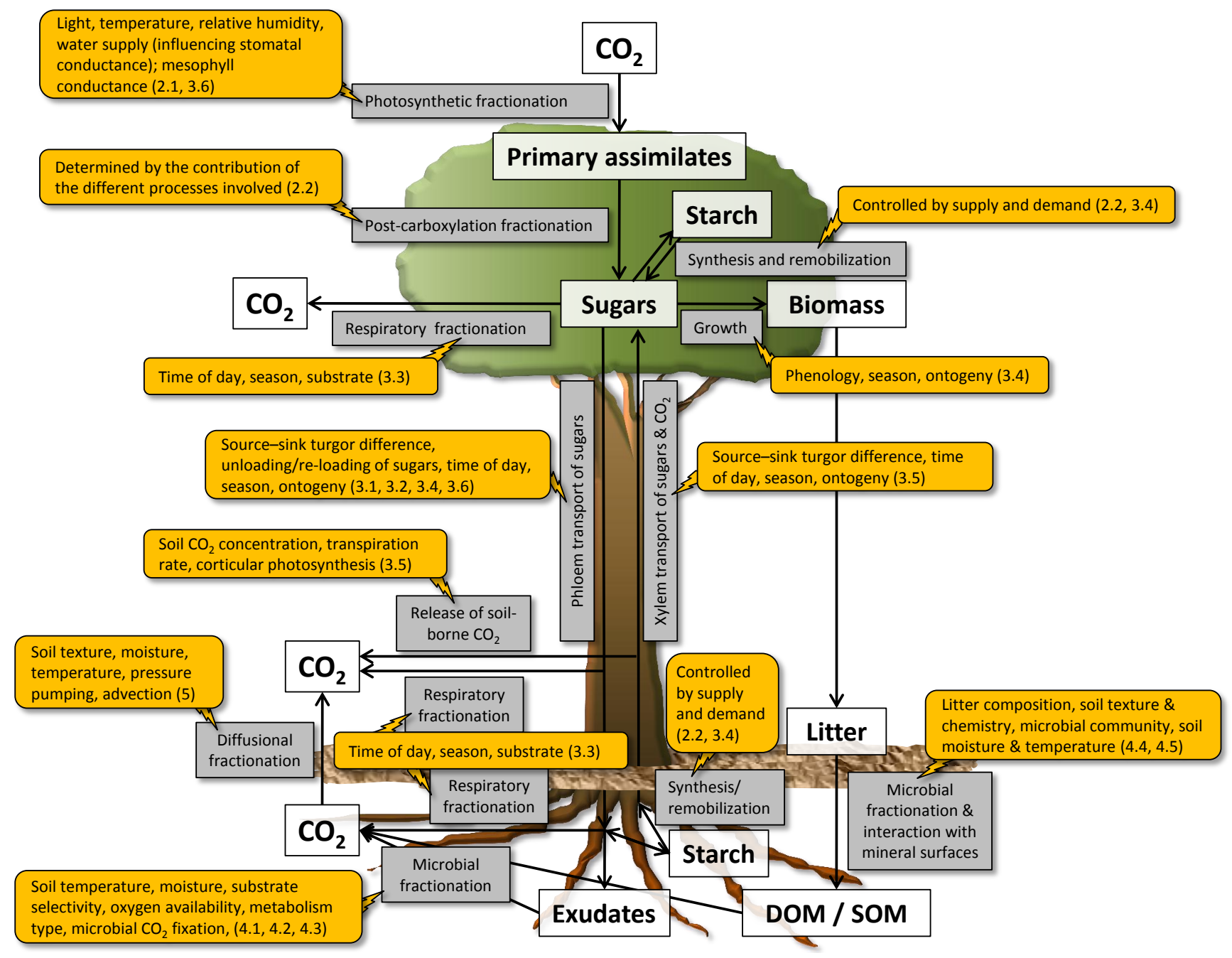

Fig. 4. Overview of processes and factors determining the isotope signature of $\mathrm{C}$ pools and fluxes in space and time in the plant-soilatmosphere continuum. White boxes represent pools, gray boxes show fractionation or other processes determining the $\mathrm{C}$ isotope composition of the involved compounds, and orange boxes depict control factors. The numbers in parentheses refer to the respective chapters of the review.

of amino acids and fatty acids (Feisthauer et al., 2008) and could have a significant impact on the overall isotopic signal of microbial biomass and the $\mathrm{CO}_{2}$ respired. Furthermore, autotrophic and photoautotrophic $\mathrm{CO}_{2}$-fixation must be considered in terms of $\mathrm{C}$ fractionation. On the one hand, the 3-hydroxypropionate pathway causes smaller isotopic fractionation $(-13$ to $14 \%$ ) compared to the Calvin cycle $(-20$ to $-25 \%$, van der Meer et al., 2007, and references therein), which is of special importance in systems where microbial mats and cyanobacteria play a large role in $\mathrm{C}$ translocation to soil and soil microbial biomass. On the other hand, autotrophic organisms may express a high level of isotopic fractionation, and fractionation has been reported to be interestingly high within the context of inorganic $\mathrm{C}$ fixation (Cowie et al., 2009).

Methodologies to study microbial biosynthesis and metabolomics are becoming increasingly more sophisticated
(Tang et al., 2009), and studies using these techniques may provide a clear basis from which isotopic differences between substrate and microbial biomass and overall microbial fractionation could be understood. For example, the use of positional labeling of carbon in glucose has given metabolic insight into carbon pathways in mycorrizhae (Scandellari et al., 2009). Studies that assess the isotopic composition of soil microbial biomass usually treat soil microbes as a single $\mathrm{C}$ pool without differentiating between metabolically active and dormant microorganisms (Šantrûčková et al., 2000; Lerch et al., 2011). Soil microbial biomass is composed of both active and dormant microorganisms, yet, $\mathrm{CO}_{2}$ respired from microorganisms derives solely from those that are metabolically active (Stenstrom et al., 2001; Werth and Kuzyakov, 2008, 2009; Millard et al., 2010; Werth and Kuzyakov, 2010). Hence, comparing isotopic composition of soil microorganisms as a single $\mathrm{C}$ pool to soil $\mathrm{CO}_{2}$ respired 
could lead to a misinterpretation of the real isotopic effects of fractionation during soil respiration. Furthermore, soil microorganisms as well as roots accumulate $\mathrm{C}$ reserves (Plateau and Blanquet, 1994; Ekblad and Högberg, 2000; Sylvia et al., 2005). This is especially true as soil microorganisms have the capacity to undergo dormancy in sudden adverse environmental conditions. To cope with these conditions, accumulated $\mathrm{C}$ in soil microorganisms can be replaced and released by adding readily available $\mathrm{C}$ (Bremer and van Kessel, 1990; Wu et al., 1993; Ekblad and Högberg, 2000; Ekblad et al., 2002). Therefore, due to the internal $\mathrm{C}$ reserves of microbes, a mixing occurs between available and stored $\mathrm{C}$ respiratory substrate, and, consequently, a flawed interpretation of kinetic fractionation during soil microbial respiration may result.

When fractionation of belowground carbon pools is calculated, the uncertainty increases with an increasing degree of metabolic separation between the actual substrate respired and the specific organism respiring. In fact, researchers have already recognized the limitation in defining fractionation as the difference between SOC and microbial biomass by referring to the estimate as "apparent fractionation". This term implies an unknown level of ambiguity and perhaps it is best to avoid its use in favor of discussing potential fractionation due to biogeochemistry and microbial metabolism. Ultimately, the research question asked will drive the level of detail to which fractionation is discussed. For example, in research describing patterns at the ecosystem scale the difference in $\delta^{13} \mathrm{C}$ between the actual $\mathrm{C}$ respired (detected in $\delta^{13} \mathrm{C}$ of $\mathrm{CO}_{2}$ ) and SOM may suffice to understand belowground $\mathrm{C}$ dynamics in soils at larger scales. However, if the research requires a high degree of precision in estimating microbial fractionation, in partitioning studies for example, then a more sophisticated methodology and quantification is required.

\subsection{Interactions with mineral surfaces}

As found in studies of SOM $\delta^{13} \mathrm{C}$ patterns with depth, isotopic enrichment occurs with an increase in fine soil particles (Solomon et al. 2002; Bird et al., 2003). Moreover, Wynn et al. (2005) found that in coarse textured soils Rayleigh fractionation did not account for patterns of SOM ${ }^{13} \mathrm{C}$ enrichment with depth, raising the question of the effect of soil texture, soil mineralogy and chemistry on the pattern of SOM ${ }^{13} \mathrm{C}$ enrichment with depth. Soil texture also plays a predominant role in carbon stabilization in soil for which the mechanisms are not entirely understood (Plante et al., 2006). However, stabilization studies using $\delta^{13} \mathrm{C}$ have shed light on the carbon dynamics of organo-mineral association (Kayler et al., 2011) and the role plants play in carbon stabilization below ground.

Analysis of stable isotopes in soil fractions has given some insight into the mechanisms behind SOM stabilization. Studies that have analyzed the isotopic signature of SOM fractions (beyond $\mathrm{C}_{3} / \mathrm{C}_{4}$ labeling techniques) have found patterns of enrichment of $\delta^{13} \mathrm{C}$ and $\delta^{15} \mathrm{~N}$ with increasing density of sequentially separated SOM fractions (Huygens et al., 2008; Sollins et al., 2009; Marin-Spiotta et al., 2009). Using several chemical techniques including isotopes, Mikutta et al. (2006) showed that organo-mineral interactions accounted for over $70 \%$ of the carbon stabilized in the soils they analyzed. Organo-mineral interactions refer to the bonding of organic matter via polyvalent cations to mineral surfaces (von Lützow et al., 2006). Using isotopes, Mikutta et al. (2006) also substantiated the role of microbial exudates and biomass providing coatings over minerals allowing for more efficient sorption (Kleber et al., 2005) as well creating chemically resistant organic matter. The authors also found that recently deposited organic material can be stabilized with mineral surfaces, suggesting that plantsoil interactions can also directly lead to carbon stabilization, long thought of as a slow process driven by decomposition only.

While changes in soil organic matter appear slow, because the pool is so vast, the processes of carbon loss and stabilization occur relatively rapidly. Questions still remain concerning how strongly organic matter is bonded to the mineral surface and to surrounding layers of the organo-mineral complex (Kleber et al., 2005). However, this research does suggest that plants may play a pivotal role in the fast cycles of carbon stabilization (Trumbore, 2006). Isotopes used toward identification of carbon stabilization mechanisms belowground are just in their infancy, and with the help of models (Kleber et al., 2007) and soil properties, we will be able to explain not only patterns of the $\delta^{13} \mathrm{C}$ of SOM with depth, but also questions regarding carbon accumulation and stabilization (Kleber et al., 2011).

\subsection{Transfer of C from leaf litter and DOC to soil and microbes}

Apart from the primary flux of $\mathrm{C}$ from plant assimilates into soil, plant litter degradation and the subsequent $\mathrm{C}$ distribution into soil carbon pools and microbial communities provide an important secondary flow of carbon into the soil (Elfstrand et al., 2008). For example, soil microbial dynamics are controlled through complex interactions with plants and are influenced by a range of organic compounds added to soils from plants as root exudates and as litter inputs (Butler et al., 2004; Bardgett et al., 2005; Kaštovská and Šantrûčková, 2007; Elfstrand et al., 2008; Denef et al., 2009; Esperschütz et al., 2009). Thus, a key issue in studies investigating soil carbon dynamics has been tracing the carbon input into soil from leaf litter decomposition (Liski et al., 2002; Dungait et al., 2010).

Leaf litter decomposition is the breakdown of highly organized plant tissue to complex organic compounds that is regulated by both biotic and abiotic processes. Since decomposition is slow, the aboveground litter layer of an ecosystem is composed of a continuum of fresh litter to completely 
humified organic matter and serves as a bottleneck for a significant portion of primary productivity sent belowground. But there still remain a series of questions of (i) how the carbon in the aboveground litter layer reaches the mineral soil, (ii) how the biogeochemical processes determine the fate of organic matter, either remaining in the aboveground litter layer or being transported into the soil profile, and (iii) which mechanisms control leaf litter-microbe interactions and dynamics. These questions have important ramifications for the carbon cycling of ecosystems and for the use of isotopes to elucidate the complex chemical nature of litter decomposition and incorporation into soil organic matter.

To a large extent, the isotopic composition of leaf litter is determined by the plant organs and tissues deposited as well as the post-carboxylation fractionation that occurred during their synthesis (see Sect. 2.2). For example, roots and woody stems are generally enriched in ${ }^{13} \mathrm{C}$ when compared to leaves, and the isotopic signature of organic matter in the litter layer is often close in value to the isotopic composition of aboveground plant organs (Badeck et al., 2005). Thus, the different ${ }^{13} \mathrm{C}$ signals of heterotrophic and autotrophic plant organs and their turnover times may affect the isotopic composition of the litter layer. Scartazza et al. (2004) found no significant variation in $\delta^{13} \mathrm{C}$ of the litter layer in a beech forest in the central Apennine Mountains, Italy, when there was a significant seasonal change in $\delta^{13} \mathrm{C}$ values in leaves and in phloem sap sugar. In the study by Scartazza et al. (2004), there was a significant relationship between leaf sugar $\delta^{13} \mathrm{C}$ and ecosystem-respired ${ }^{13} \mathrm{CO}_{2}$. Thus, the different ${ }^{13} \mathrm{C}$ signals of heterotrophic and autotrophic plant organs may control ${ }^{13} \mathrm{CO}_{2}$ produced from the ecosystem for some extent, but in terms of litter layer ${ }^{13} \mathrm{C}$, other $\mathrm{C}$ sources may be determining the $\delta^{13} \mathrm{C}$ of litter layer (e.g. lipids), and $\mathrm{C}$ with a short turn over time (e.g. sugars) may not influence the $\delta^{13} \mathrm{C}$ of litter layer.

Beyond the initial composition of litter, mechanisms behind the isotopic patterns in leaf litter are considered to be (1) selective preservation of recalcitrant compounds that are depleted in ${ }^{13} \mathrm{C}$, (2) preferential consumption of ${ }^{12} \mathrm{C}$ by microbes, (3) incorporation of exogenous organic matter, and (4) transport of dissolved organic matter within the soil profile (Nadelhoffer and Fry, 1988). Preston et al. (2009) found that patterns in the isotopic signal of leaf litter located on the soil surface depend on the degree of decomposition. The decomposing leaf litter tended to become more ${ }^{13} \mathrm{C}$-depleted with a decrease in the amount of the original litter mass. Only after about $<30 \%$ of the original litter material was remaining, the isotopic composition shifted towards an enriched signal. They attributed this shift to sorption of older soil organic carbon to the remaining leaf litter. Osono et al. (2008), found a similar depletion of litter over a three-year period of decomposition. However, they inferred isotopic patterns of leaf litter were a result of selective $\mathrm{C}$ loss as a function of lignin concentration. Thus, patterns in the isotopic signature of leaf litter are a function of decomposition and the degree to which it is integrated with mineral soil, an important consideration when using litter carbon as a tracer source for studies of carbon belowground.

Isotopic studies of the role of leaf litter input into the mineral soil has yielded a better understanding of carbon cycling and stabilization at the soil surface and carbon transported to deeper soil horizons. Bird et al. (2008) found more than half of the needle carbon had been lost from the top $5 \mathrm{~cm}$ of soil after 1.5 years, similar to loss rates reported by Müller et al. (2009). Furthermore, the ${ }^{13} \mathrm{C}$ of decomposed leaf litter remained in the light fraction of pools and was not physically protected within soil aggregates. Similarly, Rubino et al. (2010) found in a decomposition experiment with ${ }^{13} \mathrm{C}$ labeled litter that up to one third of the litter mass was lost as $\mathrm{CO}_{2}$, while the rest was transported into the mineral soil. Within the mineral soil, Kramer et al. (2010) found that microbes used $<10 \%$ of leaf litter carbon for respiration or growth and did not utilize dissolved organic carbon (DOC) from the organic horizon as a carbon source.

The carbon in the leaf litter can be characterized to have three fates: initial mineralization by microbes and soil fauna, stored as readily available substrate in the upper mineral horizons, and transported to deeper horizons (Froegberg et al., 2007; Sanderman and Amundson, 2008; Kindler et al., 2011).

Carbon compounds from aboveground litter are one source of DOC (Kindler et al., 2011), and roots are a significant, if not the predominant, contributor as well (Kramer et al., 2010). Up to $70 \%$ of the DOC originating from leaf litter can be degraded within four weeks (Müller et al., 2009), which illustrates how fast this pool turns over and supports the notion that DOC production is the rate-limiting step of soil respiration (Bengtson and Bengtsson, 2007; Cleveland et al., 2007). Because of the high turnover of DOC (2 to 3 times per day; Kalbitz et al., 2000; Bengtson and Bengtsson, 2007; Giesler et al., 2007) it is difficult to measure concentrations and isotopic composition in the litter layer, though general patterns have been observed. Sanderman et al. (2008) found a pattern of DOC ${ }^{13} \mathrm{C}$ enrichment with depth. Using batch adsorption experiments, they found that the ${ }^{13} \mathrm{C}$ enrichment of DOC with depth was best explained by exchange of organic matter between the liquid and the solid phase, as the soil solution moves through the soil profile, independent of net adsorption or net desorption of DOC. This finding substantiates the hypothesis that the mechanism behind DOC ${ }^{13} \mathrm{C}$ enrichment with depth is a continuous exchange of carbon in the soil solution and older organic matter in the soil. Regardless whether the carbon originates from aboveground or belowground litter, DOC is an important driver of rapid carbon cycling belowground and also a fast moving pool of old and new carbon that contributes to the isotopic signature of stabilized soil carbon.

Microbial communities are also regulated by litter input (Eilers et al., 2010), and communities can change rapidly depending on the available substrate (Cleveland et al., 2007). 
Through stable isotope probing (SIP), i.e. detecting and quantifying isotopic tracers in DNA of the organisms of interest, it is now possible to characterize microbial communities utilizing carbon from ${ }^{13} \mathrm{C}$-labeled litter or continuous ${ }^{13} \mathrm{C}$-labeling. Using ${ }^{13} \mathrm{C}$-enriched litter in a poplar plantation, Rubino et al. (2010) have shown that Gram-positive bacteria are primarily involved in litter degradation compared to other microbial groups (Gram-negative bacteria, actinomycetes and fungi). This finding was based on detection of significant levels of ${ }^{13} \mathrm{C}$ in all PLFAs, indicating high amounts of litter $\mathrm{C}$ incorporated into the whole soil microbial biomass. Gram-positive bacteria were the dominant group in the soil and contained around $75 \%$ litter-derived $\mathrm{C}$ assimilated by the soil microbial biomass after one year. However, after 11 months, similar $\delta^{13} \mathrm{C}$ values across all the microorganisms illustrated either (1) a similar litter $\mathrm{C}$ incorporation by all microbial communities, or (2) that the system had been at steady state after 11 months such that incorporated litter $\mathrm{C}$ was being recycled within the soil microbial biomass.

Uncertainty still remains in microbial community analysis and potential carbon sources. For example, Kramer et al. (2010) showed that the source of carbon in the biomarkers present in their incubation studies did not originate from litter or SOM, leaving only roots as the primary source. Using fatty acid methyl ester isotopic composition, Lerch et al. (2011) found a switch in the active microbial community from Gram-negative bacteria initially, which consumed the easily degradable and water-soluble substrates, to Grampositive bacteria and fungi later. Based on their isotopic measurements, Lerch et al. (2011) also suggested that there is a potential lag between changes in the bacteria actually consuming carbon belowground, and the community structure as a whole.

Leaf and root litter are important links coupling the shortand long-term carbon cycles belowground, and many open questions remain in resolving their dynamics. Of particular interest will be the fate of organic molecules derived from plant litter as they travel through the many branching points belowground. How these molecules vary spatially and temporally and whether or not they are available as substrate or physically occluded in the soil matrix are other challenges to elucidating plant-soil interactions. Isotopes will remain an important tool in tracing the carbon continuum, especially with the advent of new tools that give higher resolution spatially, for example nanoSIMS, and temporally, for example infrared laser absorption spectroscopy (Sect. 6).

\section{Physical interactions in soil-atmosphere $\mathrm{CO}_{2}$ exchange}

Section 4 illustrates the complexity of carbon sources belowground; yet, understanding how $\mathrm{C}$ is released from a stabilized state in soil and released as $\mathrm{CO}_{2}$ is a priority to determine soil as a net source or sink of $\mathrm{C}$ to the global greenhouse budget. Measuring soil respiration is arguably the best method to quantify the release of active $\mathrm{C}$ from these belowground organic and mineral sources. Thus, the $\mathrm{C}$ isotopic signature of soil respiration $\left(\delta^{13} \mathrm{C}_{\mathrm{R}-\mathrm{s}}\right)$ can be a promising tool to partition $\mathrm{C}$ sources of soil respiration, monitor belowground biological activity, and potentially identify and quantify the mechanisms of $\mathrm{C}$ stabilization and release. One of the inherent limitations of isotopic partitioning of respiration is the similar isotopic composition of potential sources, thus, achieving precise estimates of the $\delta^{13} \mathrm{C}$ of soil $\mathrm{CO}_{2}$ efflux $\left(\delta^{13} \mathrm{C}_{\mathrm{R}-\mathrm{s}}\right)$ requires the reduction of measurement artifacts as well as validation of measurement assumptions. This is why it is important to recognize the potential physical interactions of $\delta^{13} \mathrm{C}_{\mathrm{R}-\mathrm{s}}$ with the soil and the potential outcomes which can manifest in isotopic fractionation, time lags from production sources, and non-steady-state events.

There are several physical processes that occur along the pathway of soil $\mathrm{CO}_{2}$ from soil to surface which can lead to fractionation including physical and chemical effects on gas transport as well as $\mathrm{CO}_{2}$ production rates and near-surface atmospheric boundary conditions (Severinghaus et al., 1996; Bowling et al., 2009; Nickerson and Risk 2009a,b; Kayler et al., 2010b; Moyes et al., 2010; Gamnitzer et al., 2011). Gaseous diffusion of $\mathrm{CO}_{2}$ can lead to the most ${ }^{13} \mathrm{C}$-enriched signal when Knudsen diffusion (where diffusive transport is dominated by the collision of $\mathrm{CO}_{2}$ molecules with pore walls instead of other gas molecules) dominates, or it can lead to incorrect estimates of fractionation if transport is not at steady state (Bowling et al., 2009; Kayler et al., 2010b). Correctly or not (Clifford and Hillel, 1986), gaseous diffusion is assumed to dominate soil gas transport. However, estimates of the diffusion coefficient $\left(D_{\mathrm{s}}\right)$ are often a parameter of high uncertainty. In a detailed analysis of soil production estimates made from profile $\mathrm{CO}_{2}$ measurements, Koehler et al. (2010) demonstrated that the models used to interpolate diffusion over soil depth are highly dependent on the functions used to describe the distribution of $\mathrm{D}_{\mathrm{s}}$. Furthermore, they suggest that water within soil aggregates may result in $\mathrm{CO}_{2}$ storage that is not accounted for in current models. Models of diffusion that incorporate the van Genuchten function of soil hydraulic conductivity (van Genuchten, 1980) have shown initial success in accounting for soil moisture effects on diffusion (Resurreccion et al., 2008). However, these strategies have yet to be developed for isotopic fractionation and mixing.

Transport of $\mathrm{CO}_{2}$ to the soil surface induced by pressure pumping during fluctuations in wind speed or background atmospheric conditions can be a considerable component of total surface flux (Lewicki et al., 2003; Takle et al., 2003, 2004; Poulsen and Møldrup, 2006). Only a few studies exist that describe $\delta^{13} \mathrm{C}$ behavior of $\mathrm{CO}_{2}$ during advective gas transport. A sustained bulk flow, due to advection, will transport ${ }^{13} \mathrm{CO}_{2}$ and ${ }^{12} \mathrm{CO}_{2}$ at the same rate leading to a $\delta^{13} \mathrm{C}$ of $\mathrm{CO}_{2}$ at the surface that is similar to the soil gas (Camarda et al., 2007). However, advection due to 
small pressure perturbations associated with chamber placement on the surface could also result in a higher representation of ${ }^{13} \mathrm{C}$-enriched $\mathrm{CO}_{2}$ from the soil pore space in the mixture that arrives in the surface chamber leading to biased estimates of $\delta^{13} \mathrm{C}_{\mathrm{R}-\mathrm{s}}$ (Kayler et al,. 2010b; Phillips et al., 2010). A difficult challenge is quantifying and modeling soil surface concentrations (Moyes et al., 2010). The dynamics at the surface can be attributed to potential evening concentration build-up, or fluctuations in surface wind speed. Indeed, in a well-controlled study, Moyes et al. (2010) found the physical dynamics at the soil surface to drive the diel fluctuations at their site. Evidence also exists of bias in estimates of $\delta^{13} \mathrm{C}_{\mathrm{R}-\mathrm{s}}$ due to advection from wind events in snow in a subalpine forest (Bowling et al., 2009). However, there are very few isotopic studies that have observed and quantified the effects of alternative gas transport mechanisms in soil nor, for that matter, have corrections been developed.

It is clear that gas transport can have a strong impact on the relative gradient between ${ }^{13} \mathrm{CO}_{2}$ and ${ }^{12} \mathrm{CO}_{2}$ in the soil profile, but gradients in soil temperature and water vapor can also result in changes in the concentration gradient, independent of diffusive or advective transport mechanisms. In the case of temperature, the lighter isotope tends to move toward the warmer end of the gradient, while the heavier isotope moves toward the cooler end (Grew and Ibbs, 1952). Likewise, an enrichment in soil gas isotopic composition occurs with an increase in water vapor flux from soil (Severinghaus et al., 1996) and has been calculated to ${ }^{13} \mathrm{C}$ fractionation of $\mathrm{CO}_{2}$ of $0.12 \%$. Moreover, in the same study, several estimates of $\delta^{13} \mathrm{C}_{\mathrm{R}-\mathrm{s}}$ were driven out of steady state by the soil temperature gradient, which can be corrected for (Severinghaus et al., 1996). These findings are based on discrete measurement of $\delta^{13} \mathrm{C}_{\mathrm{R}-\mathrm{s}}$ and the dominant factors that impact isotope fractionation during ${ }^{13} \mathrm{CO}_{2}$ efflux may be further resolved when continuous measurements of both $\delta^{13} \mathrm{C}_{\mathrm{R}-\mathrm{s}}$ and soil physical factors are analyzed.

Although it has been known that these fractionation mechanisms exist, the problem remains how to recognize them in the field. This is difficult to overcome when relying solely on the flux off the soil surface, as with chamber measurements, because the information contained in this flux is the end-product of many processes occurring belowground, processes that are assumed to be at steady-state during the measurement period (Livingston et al., 2005). To account for this black box approach, dynamic production-transport models are used, but these do not account for most of the potential fractionation mechanisms described previously, nor do they include the uncertainty surrounding the parameters (e.g. diffusion) used to model soil gas isotopic fractionation and transport. Subsurface gas measurements have shown promise for achieving robust estimates of $\delta^{13} \mathrm{C}_{\mathrm{R}-\mathrm{s}}$, and allowing analysis of fractionation and validation of steadystate assumptions (Andrews et al., 2000; Steinmann et al., 2004; Kayler et al., 2008, 2010b; Moyes et al., 2010). However, questions still remain concerning this approach. Is, for instance, the flux from the litter layer well represented? Or, is the assumption of a homogenously mixed source gas realistic? Related to this latter point is the use of isotopic mixing models. Kayler et al. (2010c) have shown that respiration measurements, such as from soil, tend to be more accurate and precise when the Miller-Tans model used with the geometric mean regression is applied to the data, because of the relatively large measurement error that occurs with measuring high $\mathrm{CO}_{2}$ concentration gas. The Keeling mixing models used with chambers have also been shown to have a bias that results in enriched estimates of $\delta^{13} \mathrm{C}_{\mathrm{R}-\mathrm{s}}$ with increasing sampling time (Nickerson and Risk, 2009b). Therefore, until a robust method for measuring $\delta^{13} \mathrm{C}_{\mathrm{R}-\mathrm{s}}$ is developed that accounts for these physical processes, future studies will need to incorporate all three approaches: soil chamber, $\mathrm{CO}_{2}$ profile and transport-production models (e.g. Moyes et al., 2010).

Physical isotopic fractionation and mixing processes do not occur independently, and they often interact with changes in soil biological processes posing a further challenge to studies of $\delta^{13} \mathrm{C}_{\mathrm{R}-\mathrm{s}}$. For example, changes in rates of production also alter the isotopic signal at the soil surface, the faster diffusing ${ }^{12} \mathrm{CO}_{2}$ isotopologue arrives at equilibrium first, thus, an increase in production results in a depleted signal and a decrease in production results in an enriched signal (Amundson et al., 1998; Nickerson and Risk, 2009a). The way forward in $\delta^{13} C_{R-s}$ research is to account for these effects associated with soil physical properties, so that biological phenomena related to the soil-plant-atmosphere continuum can be characterized accurately.

\section{Stable isotope methodologies for characterizing $\mathrm{C}$ fluxes in the plant-soil-atmosphere continuum}

Steady-state ${ }^{13} \mathrm{C}$ isotope labeling techniques have been successfully applied to assessing $\mathrm{C}$ fluxes in metabolic networks on a cell or on tissue level. Carbon fluxes are determined by measuring the redistribution of label after the system has reached an isotopic steady state (Allen et al., 2009). Steadystate ${ }^{13} \mathrm{CO}_{2}$ labeling in combination with the application of compartmental models have been used to characterize different metabolic pools with distinct turnover times, feeding growth (Lattanzi et al., 2005) or respiration (Lehmeier et al., 2008) of leaves or heterotrophic plant parts.

A more detailed analysis of $\delta^{13} \mathrm{C}$ in particular metabolites - going beyond the separation into different $\mathrm{C}$ pools (e.g. Xu et al., 2004; Gessler et al., 2009a) - is possible with modern continuous-flow coupling of liquid chromatography (LC-IRMS; cf. Godin et al., 2007) or gas chromatography (GC-IRMS; cf. Sessions, 2006) with isotope-ratio mass spectrometry and, when high levels of ${ }^{13} \mathrm{C}$ label are applied, also with LC-MS/MS (LC coupled to tandem mass spectrometer) systems. These techniques may be combined with pulse or steady-state labeling and metabolic flux analysis models 
(e.g. Nöh et al., 2007) to provide deeper insights into cellular to whole-plant partitioning and transport of metabolites. In addition, compound-specific analyses of the $\mathrm{C}$ isotope composition at natural abundance levels over time might give insights into the turnover times and partitioning of $\mathrm{C}$ between metabolites and metabolite groups (e.g. leaf waxes; Gessler et al., 2007)

The natural variation of stable isotope signatures has been tracked through different plant organic matter pools (e.g. starch, water-soluble organic matter) in order to characterize the short-term partitioning of recent assimilates (e.g. Barbour et al., 2005; Brandes et al., 2006; Gessler et al., 2007; Kodama et al., 2008; see also 2.1). On an ecosystem scale, the interpretation of isotopic signals at the natural abundance level is challenging, as too many processes affect the isotopic signatures of the compounds of interest. Therefore, partitioning and transport of newly assimilated C within the plant-soil system have been mainly determined with pulse labeling experiments. In these experiments, plants are exposed to ${ }^{13} \mathrm{C}$-enriched $\mathrm{CO}_{2}$ for a short time period (minutes to a few hours), and the fate of the assimilated $\mathrm{C}$ tracer is tracked in various plant organs and/or in plant- and soil-respired $\mathrm{CO}_{2}$ over time (Bahn et al., 2009; Plain et al., 2009; Ruehr et al., 2009; Ghirardo et al., 2011). In addition, nanoSIMS, i.e. secondary ion mass spectrometry, which allows determination of stable isotope ratios at the nanometer scale, could contribute to understanding carbon allocation in the rhizosphere.

While application of the widespread isotope ratio mass spectrometry technique for analyzing time series of carbon isotopic signatures in plant materials and respired $\mathrm{CO}_{2}$ is costly and labor-intensive, isotope-specific infrared laser absorption spectroscopy, e.g. for the analysis of ${ }^{13} \mathrm{C}$ and ${ }^{18} \mathrm{O}$ in $\mathrm{CO}_{2}$, which equals or even exceeds the performance of isotope ratio mass spectrometry, provides great opportunities to measure changes in carbon and oxygen isotopic signatures in $\mathrm{CO}_{2}$ at the chamber and ecosystem level at high temporal resolution in situ (Bowling et al., 2003; Bahn et al., 2009; Plain et al., 2009). The continuous and simultaneous analysis of photosynthetic fractionation in the canopy (e.g. carried out with leaf or twig chambers) or its proxies and of $\delta^{13} \mathrm{C}$ of $\mathrm{CO}_{2}$ respired from heterotrophic plant parts and the soil with laser-based isotope analyzers provides information on the time lag between above- and belowground processes and the magnitude of $\mathrm{C}$ fluxes between canopy and soil as well as on their variability during the growing season or as influenced by environmental factors. This will help improve our understanding of environmental effects on $\mathrm{C}$ uptake and storage capacity of terrestrial ecosystems, which will be particularly important in the future with higher frequency and magnitude of extreme events (IPCC, 2007).

\section{Conclusions and outlook}

This review has provided a comprehensive overview of the complex network of interlinked carbon transformation and transport processes in the plant-soil-atmosphere continuum and their implications for carbon isotopic signatures of the different compounds at different stages and locations (Fig. 4). It has given evidence of the tight coupling of processes in the plant-soil system, which calls for more integrated multidisciplinary approaches towards understanding plant and ecosystem $\mathrm{C}$ dynamics, combining the fields of (eco)physiology, microbiology and soil sciences. Furthermore, this review has demonstrated that research using information from $\mathrm{C}$ isotopes is a powerful tool permitting both tracing of $\mathrm{C}$ molecules and an integrated view of physical, chemical and biological processes in ecosystems across space and time. However, the review has also shown the current limitations and frontiers in the field, indicating that multiple interactions between biochemical processes at the cellular level, whole-plant physiology including plant-internal C translocation, biotic interactions as well as physiological and physical fractionation steps may complicate the interpretation of isotopic signatures at the plant and ecosystem scale.

Amongst the emerging research questions that may need to be addressed in the near future we highlight the following:

- How do environmental factors and plant physiology affect post-carboxylation $\mathrm{C}$ isotope fractionation? How do changes in these fractionation processes translate into metabolic flux information?

- How do changes in metabolic fluxes scale to ecosystem C fluxes?

- What is the relationship between the age of plant C stores and their remobilization potential, and how is it affected by plant age, phenology, and environmental conditions?

- What processes determine the coupling of photosynthesis and respiration, especially between canopy and soil? What is the role of the transfer of $\mathrm{C}$ via sugars in the phloem versus indirect signaling effects (including pressure concentration waves)? Are such effects universal or do they differ between plant species/ functional types and seasons?

- What is the role of physical (diffusion, dissolution) and physiological (re-fixation) processes as co-determinants of $\delta^{13} \mathrm{C}$ measured in plant- and soil-respired $\mathrm{CO}_{2}$ and how do these processes affect isotopic time lags between photosynthesis and respiration?

- How does environmental stress affect $\mathrm{C}$ fluxes in the plant-soil system?

- How pronounced is the upward $\mathrm{CO}_{2}$ transport from roots to aboveground plant organs across plant species/ 
functional types and seasons, and how does it affect plant and ecosystem $\mathrm{C}$ dynamics and $\mathrm{C}$ isotope signatures?

- How strongly do plant-microbe interactions and related priming effects influence SOM turnover, $\mathrm{C}$ retention in microbial biomass and SOC isotope composition? How much are they determined by vegetation composition and how are they modified by changing environmental conditions?

Addressing these questions with the emerging technologies will likely permit major progress towards our understanding of environmental effects on C uptake, allocation, storage and release in the plant-soil system and thereby contribute to improving our projections of the $\mathrm{C}$ cycle in a rapidly changing environment.

Acknowledgements. This review is an outcome of the conference "Stable Isotopes and Biogeochemical Cycles in Terrestrial Ecosystems" in Monte Verità, Ascona, Switzerland, in March 2010. We acknowledge co-funding of this conference by the COST Action ES0806 SIBAE (Stable Isotopes in Biosphere-Atmosphere-Earth System Research). Arthur Gessler acknowledges financial support by the DFG (Deutsche Forschungsgemeinschaft). Jürgen Esperschütz acknowledges the Transregional Collaborative Research Centre 38 (SFB/TRR38), which is financially supported by the DFG. Matthias Barthel and Alexander Knohl were funded by the EC Marie Curie Excellence grant ISOCYCLE under contract no. MEXTCT-2006-042268. Michael Bahn acknowledges financial support by the Austrian Science Fund projects FWF P18756-B16 and P22214-B17 as well as the EU-project CARBO-Extreme, GA no. 226701 (FP7/2007-2013). Zachary Kayler would like to thank Delphine Derriene and Markus Kleber for reviewing the SOM section.

Edited by: A. Neftel

\section{References}

Accoe, F., Boeckx, P., Cleemput, O. V., Hofman, G., Zhang, Y., Li, R. H., and Guanxiong, C.: Evolution of the $\delta^{13} \mathrm{C}$ signature related to total carbon contents and carbon decomposition rate constants in a soil profile under grassland, Rapid Commun. Mass Spectrom., 16, 2184-2189, 2002.

Affek, H. P. and Yakir, D.: Natural abundance carbon isotope composition of isoprene reflects incomplete coupling between isoprene synthesis and photosynthetic carbon flow, Plant Physiol., 131, 1727-1736, 2003.

Allen, D., Libourel, I., and Shachar-Hill, Y.: Metabolic flux analysis in plants: coping with complexity, Plant Cell Environ., 32, 12411257, 2009.

Amundson, R., Stern, L., Baisden, T., and Wang, Y.: The isotopic composition of soil and soil-respired $\mathrm{CO}_{2}$, Geoderma, 82, 83 114, 1998.

Andrews, J. A., Harrison, K. G., Matamala, R., and Schlesinger, W. H.: Separation of root respiration from total soil respiration using carbon-13 labeling during Free-Air Carbon Dioxide Enrichment (FACE), Soil Sci. Soc. Am. J., 63, 1429-1435, 1999.

Andrews, J. A., Matamala, R., Westover, K. M., and Schlesinger, W. H.: Temperature effects on the diversity of soil heterotrophs and the delta $\mathrm{C}-13$ of soil-respired $\mathrm{CO}_{2}$, Soil Biol. Biochem., 32, 699-706, 2000.

Asaeda, T., Sharma, P., and Rajapakse, L.: Seasonal patterns of carbohydrate translocation and synthesis of structural carbon components in Typha angustifolia, Hydrobiologia, 607, 87-101, 2008.

Aubrey, D. P. and Teskey, R. O.: Root-derived $\mathrm{CO}_{2}$ efflux via xylem stream rivals soil $\mathrm{CO}_{2}$ efflux, New Phytol., 184, 35-40, 2009.

Badeck, F. W., Tcherkez, G., Nogués, S., Piel, C., and Ghashghaie, J.: Post-photosynthetic fractionation of stable carbon isotopes between plant organs - a widespread phenomenon, Rapid Commun. Mass Spectrom., 19, 1381-1391, 2005.

Bahn, M., Knapp, M., Garajova, Z., Pfahringer, N., and Cernusca, A.: Root respiration in temperate mountain grasslands differing in land use, Glob. Change Biol., 12, 995-1006, 2006.

Bahn, M., Rodeghiero, M., Anderson-Dunn, M., Dore, S., Gimeno, S., Drösler, M., Williams, M., Ammann, C., Berninger, F., Flechard, C., Jones, S., Balzarolo, M., Kumar, S., Newesely, C., Priwitzer, T., Raschi, A., Siegwolf, R., Susiluoto, S., Tenhunen, J., Wohlfahrt, G., and Cernusca, A.: Soil respiration in European grasslands in relation to climate and assimilate supply, Ecosystems, 11, 1352-1367, 2008.

Bahn, M., Schmitt, M., Siegwolf, R., Richter, A., and Brüggemann, $\mathrm{N}$.: Does photosynthesis affect grassland soil-respired $\mathrm{CO}_{2}$ and its carbon isotope composition on a diurnal timescale?, New Phytol., 182, 451-460, 2009.

Bahn, M., Janssens, I. A., Reichstein, M., Smith, P., and Trumbore, S. E.: Soil respiration across scales: towards an integration of patterns and processes, New Phytol., 186, 292-296, 2010.

Barbour, M. M. and Hanson, D. T.: Stable carbon isotopes reveal dynamics of respiratory metabolism, New Phytol., 181, 243-245, 2009.

Barbour, M. M., Hunt, J. E., Dungan, R. J., Turnbull, M. H., Brailsford, G. W., Farquhar, G. D., and Whitehead, D.: Variation in the degree of coupling between delta C-13 of phloem sap and ecosystem respiration in two mature Nothofagus forests, New Phytol., 166, 497-512, 2005.

Barbour, M. M., McDowell, N. G., Tcherkez, G., Bickford, C. P., and Hanson, D. T.: A new measurement technique reveals rapid post-illumination changes in the carbon isotope composition of leaf-respired $\mathrm{CO}_{2}$, Plant Cell Environ., 30, 469-482, 2007.

Bardgett, R. D., Bowman, W. D., Kaufmann, R., and Schmidt, S. K.: A temporal approach to linking aboveground and belowground ecology, Trends Ecol. Evol., 20, 634-641, 2005.

Barthel, M., Hammerle, A., Sturm, P., Baur, T., Gentsch, L., and Knohl, A.: The diel imprint of leaf metabolism on the $\delta^{13} \mathrm{C}$ signal of soil respiration under control and drought conditions, New Phytol., 192, 925-938, 2011.

Bathellier, C., Badeck, F. W., Couzi, P., Harscoet, S., Mauve, C., and Ghashghaie, J.: Divergence in delta ${ }^{13} \mathrm{C}$ of dark respired $\mathrm{CO}_{2}$ and bulk organic matter occurs during the transition between heterotrophy and autotrophy in Phaseolus vulgaris plants, New Phytol., 177, 406-418, 2008.

Bathellier, C., Tcherkez, G., Bligny, R., Gout, E., Cornic, G., and Ghashghaie, J.: Metabolic origin of the delta- ${ }^{13} \mathrm{C}$ of respired 
$\mathrm{CO}_{2}$ in roots of Phaseolus vulgaris, New Phytol., 181, 387-399, 2009.

Bengtson, P. and Bengtsson, G.: Rapid turnover of DOC in temperate forests accounts for increased $\mathrm{CO} 2$ production at elevated temperatures, Ecol. Lett., 10, 783-790, 2007.

Berveiller, D. and Damesin, C.: Carbon assimilation by tree stems: Potential involvement of phosphoenolpyruvate carboxylase, Trees, 22, 149-157, 2008.

Betson, N. R., Göttlicher, S. G., Hall, M., Wallin, G., Richter, A., and Högberg, P.: No diurnal variation in rate or carbon isotope composition of soil respiration in a boreal forest, Tree Physiol., 27, 749-756, 2007.

Bird, M., Kracht, O., Derrien, D., and Zhou, Y.: The effect of soil texture and roots on the stable carbon isotope composition of soil organic carbon, Austr. J. Soil Res., 41, 77-94, 2003.

Bird, J. A., Kleber, M., and Torn, M. S.: ${ }^{13} \mathrm{C}$ and ${ }^{15} \mathrm{~N}$ stabilization dynamics in soil organic matter fractions during needle and fine root decomposition, Org. Geochem., 39, 465-477, 2008.

Blair, N., Leu, A., Munoz, E., Olsen, J., Kwong, E., and Des Marais, D.: Carbon isotopic fractionation in heterotrophic microbial metabolism, Appl. Environ. Microbiol., 50, 996-1001, 1985.

Boege, K.: Influence of plant ontogeny on compensation to leaf damage, Am. J. Bot., 92, 1632-1640, 2005.

Boege, K. and Marquis, R. J.: Facing herbivory as you grow up: the ontogeny of resistance in plants, Trends Ecol. Evol., 20, 441448, 2005.

Bond-Lamberty, B. and Thomson, A.: A global database of soil respiration data, Biogeosciences, 7, 1915-1926, doi:10.5194/bg7-1915-2010, 2010.

Boström, B., Comstedt, D., and Ekblad, A.: Isotope fractionation $\delta^{13} \mathrm{C}$ enrichment in soil profiles during the decomposition of soil organic matter, Oecologia, 153, 89-98, 2007.

Bouche, M. B.: A Method for measuring element fluxes in an undisturbed soil - Nitrogen and carbon from earthworms, Pedobiologia, 27, 197-206, 1984.

Bowling, D. R., McDowell, N. G., Bond, B. J., Law, B. E., and Ehleringer, J. R.: ${ }^{13} \mathrm{C}$ content of ecosystem respiration is linked to precipitation and vapor pressure deficit, Oecologia, 131, 113124, 2002.

Bowling, D. R., Sargent, S. D., Tanner, B. D., and Ehleringer, J. R.: Tunable diode laser absorption spectroscopy for stable isotope studies of ecosystem-atmosphere $\mathrm{CO}_{2}$ exchange, Agr. Forest Meteorol., 118, 1-19, 2003.

Bowling, D. R., Pataki, D. E., and Randerson, J. T.: Carbon isotopes in terrestrial ecosystem pools and $\mathrm{CO}_{2}$ fluxes, New Phytol., 178, 24-40, 2008.

Bowling, D. R., Massman, W. J., Schaeffer, S. M., Burns, S. P., Monson, R. K., and Williams, M. W.: Biological and physical influences on the carbon isotope content of $\mathrm{CO}_{2}$ in a subalpine forest snowpack, Niwot Ridge, Colorado, Biogeochemistry, 95, 37-59, 2009.

Brandes, E., Kodama, N., Whittaker, K., Weston, C., Rennenberg, H., Keitel, C., Adams, M. A., and Gessler, A.: Short-term variation in the isotopic composition of organic matter allocated from the leaves to the stem of Pinus sylvestris: effects of photosynthetic and postphotosynthetic carbon isotope fractionation, Glob. Change Biol., 12, 1922-1939, 2006.

Brandes, E., Wenninger, J., Koeniger, P., Schindler, D., Rennen- berg, H., Leibundgut, C., Mayer, H., and Gessler, A.: Assessing environmental and physiological controls over water relations in a Scots pine (Pinus sylvestris L.) stand through analyses of stable isotope composition of water and organic matter, Plant Cell Environ., 30, 113-127, 2007.

Bremer, E. and van Kessel, C.: Extractability of microbial ${ }^{14} \mathrm{C}$ and ${ }^{15} \mathrm{~N}$ following addition of variable rates of labelled glucose and $\left(\mathrm{NH}_{4}\right)_{2} \mathrm{SO}_{4}$ to soil, Soil Biol. Biochem., 22, 707-713, 1990.

Brüggemann, N. and Schnitzler, J. P.: Comparison of isoprene emission, intercellular isoprene concentration and photosynthetic performance in water-limited oak (Quercus pubescens Willd and Quercus robur L) saplings, Plant Biol., 4, 456-463, 2002.

Brugnoli, E. and Farquhar, G. D.: Photosynthetic fractionation of carbon isotopes, in: Photosynthesis: Physiology and Metabolism, edited by: Leegood, R. C., Sharkey, T.D., and von Caemmerer, S., Kluwer, Dordrecht, The Netherlands, 399-434, 2000.

Buchmann, N., Brooks, R., Rapp, K. D., and Ehleringer, J. R.: Carbon isotope composition of $\mathrm{C}_{4}$ grasses is influenced by light and water supply, Plant Cell Environ., 19, 392-402, 1996.

Butler, J. L., Bottomley, P. J., Griffith, S. M., and Myrold, D. D.: Distribution and turnover of recently fixed photosynthate in ryegrass rhizospheres, Soil Biol. Biochem., 36, 371-382, 2004.

Camarda, M., De Gregorio, S., Favara, R., and Gurrieri, S.: Evaluation of carbon isotope fractionation of soil $\mathrm{CO}_{2}$ under an advective-diffusive regimen: A tool for computing the isotopic composition of unfractionated deep source, Geochim. Cosmochim. Acta, 71, 3016-3027, 2007.

Carbone, M. S. and Trumbore, S. E.: Contribution of new photosynthetic assimilates to respiration by perennial grasses and shrubs: residence times and allocation patterns, New Phytologist, 176, 124-135, 2007.

Carbone, M. S., Czimczik, C. I., McDuffee, K. E., and Trumbore, S. E.: Allocation and residence time of photosynthetic products in a boreal forest using a low-level ${ }^{14} \mathrm{C}$ pulse-chase labeling technique, Glob. Change Biol., 13, 466-477, 2007.

Cavender-Bares, J. and Bazzaz, F. A.: Changes in drought response strategies with ontogeny in Quercus rubra: implications for scaling from seedlings to mature trees, Oecologia, 124, 8-18, 2000.

Cerasoli, S., Maillard, P., Scartazza, A., Brugnoli, E., Chaves, M. M., and Pereira, J. S.: Carbon and nitrogen winter storage and remobilisation during seasonal flush growth in two-year-old cork oak (Quercus suber L.) saplings, Ann. For. Sci., 61, 721-729, 2004.

Cernusak, L. A. and Marshall, J. D.: Photosynthetic refixation in branches of Western White Pine, Funct. Ecol., 14, 300-311, 2000.

Cernusak, L. A., Arthur, D. J., Pate, J. S., and Farquhar, G. D.: Water relations link carbon and oxygen isotope discrimination to phloem sap sugar concentration in eucalyptus globulus, Plant Physiol., 131, 1544-1554, 2003.

Cernusak, L. A., Tcherkez, G., Keitel, C., Cornwell, W. K., Santiago, L. S., Knohl, A., Barbour, M. M., Williams, D. G., Reich, P. B., Ellsworth, D. S., Dawson, T. E., Griffiths, H. G., Farquhar, G. D., and Wright, I. J.: Viewpoint: Why are non-photosynthetic tissues generally C-13 enriched compared with leaves in C-3 plants? Review and synthesis of current hypotheses, Funct. Plant Biol., 36, 199-213, 2009.

Chapin, F. S., McFarland, J., McGuire, A. D., Euskirchen, E. S., 
Ruess, R. W., and Kielland, K.: The changing global carbon cycle: linking plant-soil carbon dynamics to global consequences, J. Ecol., 97, 840-850, 2009.

Cheng, W. X., Zhang, Q. L., Coleman, D. C., Carroll, C. R., and Hoffman, C. A.: Is available carbon limiting microbial respiration in the rhizosphere?, Soil Biol. Biochem., 28, 1283-1288, 1996.

Cifuentes, L. A. and Salata, G. G.: Significance of carbon isotope discrimination between bulk carbon and extracted phospholipid fatty acids in selected terrestrial and marine environments, Org. Geochem., 32, 613-621, 2001.

Cisneros-Dozal, L. M., Trumbore, S., and Hanson, P. J.: Partitioning sources of soil-respired $\mathrm{CO}_{2}$ and their seasonal variation using a unique radiocarbon tracer, Glob. Change Biol., 12, 194204, 2006.

Cleveland, C., Nemergut, D., Schmidt, S., and Townsend, A.: Increases in soil respiration following labile carbon additions linked to rapid shifts in soil microbial community composition, Biogeochemistry, 82, 229-240, 2007.

Clifford, S. M. and Hillel, D.: Knudsen Diffusion: the Effect of Small Pore Size and Low Gas Pressure on Gaseous Transport in Soil, Soil Sci., 141, 289-297, 1986.

Cowie, B. R., Slater, G. F., Bernier, L., and Warren, L. A.: Carbon isotope fractionation in phospholipid fatty acid biomarkers of bacteria and fungi native to an acid mine drainage lake, Org. Geochem., 40, 956-962, 2009.

Craine, J. M., Wedin, D. A., and Chapin, F. S.: Predominance of ecophysiological controls on soil $\mathrm{CO}_{2}$ flux in a Minnesota grassland, Plant Soil, 207, 77-86, 1999.

Czimczik, C. I., Trumbore, S. E., Carbone, M. S., and Winston, G. C.: Changing sources of soil respiration with time since fire in a boreal forest, Glob. Change Biol., 12, 957-971, 2006.

Damesin, C. and Lelarge, C.: Carbon isotope composition of current-year shoots from Fagus sylvatica in relation to growth, respiration and use of reserves, Plant Cell Environ., 26, 207-219, 2003.

Dannoura, M., Maillard, P., Fresneau, C., Plain, C., Berveiller, D., Gerant, D., Chipeaux, C., Bosc, A., Ngao, J., Damesin, C., Loustau, D., and Epron, D.: In situ assessment of the velocity of carbon transfer by tracing ${ }^{13} \mathrm{C}$ in trunk $\mathrm{CO}_{2}$ efflux after pulse labelling: variations among tree species and seasons, New Phytologist, 190, 181-192, 2011.

Davidson, E. A. and Holbrook, N. M.: Is temporal variation of soil respiration linked to the phenology of photosynthesis, in: Phenology of Ecosystem Processes, edited by: Noormets, A., Springer, New York, 187-199, 2009.

Davidson, E. A., Janssens, I. A., and Luo, Y. Q.: On the variability of respiration in terrestrial ecosystems: moving beyond $\mathrm{Q}(10)$, Glob. Change Biol., 12, 154-164, 2006.

Dawson, T. and Siegwolf, R.: Isotopes as Tracers of Ecological Change, Elsevier Academic Press, San Diego, USA, 436 pp., 2007.

Dawson, T. E., Mambelli, S., Plamboeck, A. H., Templer, P. H., and Tu, K. P.: Stable isotopes in plant ecology, Annu. Rev. Ecol. Syst., 33, 507-559, 2002.

Denef, K., Roobroeck, D., Manimel Wadu, M. C. W., Lootens, P., and Boeckx, P.: Microbial community composition and rhizodeposit-carbon assimilation in differently managed temperate grassland soils, Soil Biol. Biochem., 41, 144-153, 2009.
DeNiro, M. and Epstein, S.: Mechanism of carbon isotope fractionation associated with lipid synthesis, Science, 197, 261-263, 1977.

Dickson, R. E.: Carbon and nitrogen allocation in trees, Ann. Sci. For., 46, 631-647, 1989.

Dickson, R. E., Tomlinson, P. T., and Isebrands, J. G.: Allocation of current photosynthate and changes in tissue dry weight within northern red oak seedlings: individual leaf and flush carbon contribution during episodic growth, Can. J. For. Res.-Rev. Can. Rech. For., 30, 1296-1307, 2000.

Dieuaide-Noubhani, M., Raffard, G., Canioni, P., Pradet, A., and Raymond, P.: Quantification of compartmented metabolic fluxes in maize root tips using isotope distribution from ${ }^{13} \mathrm{C}$ - or ${ }^{14} \mathrm{C}$ labeled glucose, J. Biol. Chem., 270, 13147-13159, 1995.

Diochon, A. and Kellman, L.: Natural abundance measurements of ${ }^{13} \mathrm{C}$ indicate increased deep soil carbon mineralization after forest disturbance, Geophys. Res. Lett., 35, L14402, doi:10.1029/2008GL034795, 2008.

Donovan, L. A. and Ehleringer, J. R.: Carbon-isotope discrimination, water-use efficiency, growth, and mortality in a natural shrub population, Oecologia, 100, 347-354, 1994.

Dungait, J. A. J., Bol, R., Lopez-Capel, E., Bull, I. D., Chadwick, D., Amelung, W., Granger, S. J., Manning, D. A. C., and Evershed, R. P.: Applications of stable isotope ratio mass spectrometry in cattle dung carbon cycling studies, Rapid Commun. Mass Spectrom., 24, 495-500, 2010.

Duranceau, M., Ghashghaie, J., Badeck, F., Deleens, E., and Cornic, G.: Delta $\mathrm{C}-13$ of $\mathrm{CO}_{2}$ respired in the dark in relation to delta C-13 of leaf carbohydrates in Phaseolus vulgaris L. under progressive drought, Plant Cell Environ., 22, 515-523, 1999.

Dyckmans, J., Scrimgeour, C. M., and Schmidt, O.: A simple and rapid method for labelling earthworms with N-15 and C-13, Soil Biol. Biochem., 37, 989-993, 2005.

Ehleringer, J. R., Buchmann, N., and Flanagan, L. B.: Carbon isotope ratios in belowground carbon cycle processes, Ecol. Applic., $10,412-422,2000$.

Eilers, K. G., Lauber, C. L., Knight, R., and Fierer, N.: Shifts in bacterial community structure associated with inputs of low molecular weight carbon compounds to soil, Soil Biol. Biochem., 42, 896-903, 2010.

Ekblad, A. and Högberg, P.: Analysis of $\delta^{13} \mathrm{C}$ of $\mathrm{CO}_{2}$ distinguishes between microbial respiration of added $\mathrm{C} 4$-sucrose and other soil respiration in a C3-ecosystem, Plant Soil, 219, 197-209, 2000.

Ekblad, A. and Högberg, P.: Natural abundance of ${ }^{13} \mathrm{C}$ in $\mathrm{CO}_{2}$ respired from forest soils reveals speed of link between tree photosynthesis and root respiration, Oecologia, 127, 305-308, 2001.

Ekblad, A., Nyberg, G., and Högberg, P.: $\delta^{13}$ C-discrimination during microbial respiration of added $\mathrm{C} 3-, \mathrm{C} 4-$ and ${ }^{13} \mathrm{C}$-labelled sugars to a C3-forest soil, Oecologia, 131, 245-249, 2002.

Eklund, L.: Endogenous levels of oxygen, carbon dioxide and ethylene in stems of Norway spruce trees during one growing season, Trees-Struct. Funct., 4, 150-154, 1990.

Elfstrand, S., Lagerlöf, J., Hedlund, K., and Mårtensson, A.: Carbon routes from decomposing plant residues and living roots into soil food webs assessed with ${ }^{13} \mathrm{C}$ labelling, Soil Biol. Biochem., 40, 2530-2539, 2008.

Epron, D., Ngao, J., Dannoura, M., Bakker, M. R., Zeller, B., Bazot, S., Bosc, A., Plain, C., Lata, J. C., Priault, P., Barthes, L., and Loustau, D.: Seasonal variations of belowground carbon trans- 
fer assessed by in situ ${ }^{13} \mathrm{CO}_{2}$ pulse labelling of trees, Biogeosciences, 8, 1153-1168, doi:10.5194/bg-8-1153-2011, 2011.

Esperschütz, J., Buegger, F., Winkler, J. B., Munch, J. C., Schloter, M., and Gattinger, A.: Microbial response to exudates in the rhizosphere of young beech trees (Fagus sylvatica L.) after dormancy, Soil Biol. Biochem., 41, 1976-1985, 2009.

Farquhar, G. D.: On the nature of carbon isotope discrimination in C-4 species, Aust. J. Plant Physiol., 10, 205-226, 1983.

Farquhar, G. D., O' Leary, M. H., and Berry, J. A.: On the relationship between carbon isotope discrimination and the inter-cellular carbon-dioxide concentration in leaves, Austr. J. Plant Physiol., 9, 121-137, 1982.

Farquhar, G. D., Ehleringer, J. R., and Hubick, K. T.: Carbon isotope discrimination and photosynthesis, Annu. Rev. Plant Physiol. Plant Molec. Biol., 40, 503-537, 1989.

Feisthauer, S., Wick, L. Y., Kästner, M., Kaschabek, S. R., Schlömann, M., and Richnow, H. H.: Differences of heterotrophic ${ }^{13} \mathrm{CO}_{2}$ assimilation by Pseudomonas knackmussii strain B13 and Rhodococcus opacus 1CP and potential impact on biomarker stable isotope probing, Environ. Microbiol., 10, 1641-1651, 2008.

Ferrier, J. M., Tyree, M. T., and Christy, A. L.: Theoretical timedependent behavior of a Münch pressure-flow system-effect of sinusoidal time variation in sucrose loading and water potential, Can. J. Botany, 53, 1120-1127, 1975.

Fessenden, J. E. and Ehleringer, J. R.: Age-related variations in $\delta^{13} \mathrm{C}$ of ecosystem respiration across a coniferous forest chronosequence in the Pacific Northwest, Tree Physiol., 22, 159$167,2002$.

Finlay, R. D. and Söderström, B.: Mycorrhiza and carbon flow to the soil, in: Mycorrhizal Functioning: An Integrative PlantFungal Process, edited by: Allen, M. F., Chapman \& Hall, London, 134-160, 1992.

Fisher, D. B.: Long-distance transport, in: Biochemistry and Molecular Biology of Plants, Buchanan, B., edited by: Gruissem, W. and Jones, R. L., Wiley, New York, 730-785, 2002.

Flexas, J., Ribas-Carbo, M., Diaz-Espej, A., Galmes, J., and Medrano, $\mathrm{H}$.: Mesophyll conductance to $\mathrm{CO}_{2}$ : Current knowledge and future prospects, Plant Cell Environ., 31, 602-621, 2008.

Fontaine, S., Barot, S., Barre, P., Bdioui, N., Mary, B., and Rumpel, C.: Stability of organic carbon in deep soil layers controlled by fresh carbon supply, Nature, 450, 277-280, 2007.

Foote, K. C. and Schaedle, M.: Physiological characteristics of photosynthesis and respiration in stems of populus tremuloides Michx., Plant Physiol., 58, 91-94, 1976.

Ford, C. R., Wurzburger, N., Hendrick, R. L., and Teskey, R. O.: Soil DIC uptake and fixation in Pinus taeda seedlings and its $\mathrm{C}$ contribution to plant tissues and ectomycorrhizal fungi, Tree Physiol., 27, 375-383, 2007.

Gamnitzer, U., Moyes, A. B., Bowling, D. R., and Schnyder, H.: Measuring and modelling the isotopic composition of soil respiration: insights from a grassland tracer experiment, Biogeosciences, 8, 1333-1350, doi:10.5194/bg-8-1333-2011, 2011.

Gaudinski, J. B., Torn, M. S., Riley, W. J., Swanston, C., Trumbore, S. E., Joslin, J. D., Majdi, H., Dawson, T. E., and Hanson, P. J.: Use of stored carbon reserves in growth of temperate tree roots and leaf buds: analyses using radiocarbon measurements and modeling, Glob. Change Biol., 15, 992-1014, 2009.
Genet, H., Breda, N., and Dufrene, E.: Age-related variation in carbon allocation at tree and stand scales in beech (Fagus sylvatica L.) and sessile oak (Quercus petraea (Matt.) Liebl.) using a chronosequence approach, Tree Physiol., 30, 177-192, 2010.

Gessler, A., Schrempp, S., Matzarakis, A., Mayer, H., Rennenberg, H., and Adams, M. A.: Radiation modifies the effect of water availability on the carbon isotope composition of beach (Fagus sylvatica), New Phytol., 150, 653-664, 2001.

Gessler, A., Keitel, C., Kodama, N., Weston, C., Winters, A. J., Keith, H., Grice, K., Leuning, R., and Farquhar, G. D.: $\delta^{13} \mathrm{C}$ of organic matter transported from the leaves to the roots in Eucalyptus delegatensis: short-term variations and relation to respired $\mathrm{CO}_{2}$, Funct. Plant Biol., 34, 692-706, 2007.

Gessler, A., Tcherkez, G., Peuke, A. D., Ghashghaie, J., and Farquhar, G. D.: Experimental evidence for diel variations of the carbon isotope composition in leaf, stem and phloem sap organic matter in Ricinus communis, Plant Cell Environ., 31, 941-953, 2008.

Gessler, A., Tcherkez, G., Karyanto, O., Keitel, C., Ferrio, J. P., Ghashghaie, J., Kreuzwieser, J., and Farquhar, G. D.: On the metabolic origin of the carbon isotope composition of $\mathrm{CO}_{2}$ evolved from darkened light-adapted leaves in Ricinus communis, New Phytol., 181, 374-386, 2009a.

Gessler, A., Brandes, E., Buchmann, N., Helle, G., Rennenberg, H., and Barnard, R.: Tracing carbon and oxygen isotope signals from newly assimilated sugars in the leaves to the tree ring archive, Plant Cell Environ., 32, 780-795, 2009b.

Ghashghaie, J., Badeck, F.-W., Lanigan, G., Nogués, S., Tcherkez, G., Deléens, E., Cornic, G., and Griffiths, H.: Carbon isotope fractionation during dark respiration and photorespiration in $\mathrm{C} 3$ plants, Phytochem. Rev., 2, 145-161, 2003.

Ghirardo, A., Gutknecht, J., Zimmer, I., Brüggemann, N., and Schnitzler, J. P.: Biogenic volatile organic compound and respiratory $\mathrm{CO}_{2}$ emissions after ${ }^{13} \mathrm{C}$-labeling: online tracing of $\mathrm{C}$ translocation dynamics in poplar plants, PLoS One, 6, e17393, doi:10.1371/journal.pone.0017393, 2011.

Giesler, R., Högberg, M., Strobel, B., Richter, A., Nordgren, A., and Högberg, P.: Production of dissolved organic carbon and lowmolecular weight organic acids in soil solution driven by recent tree photosynthate, Biogeochemistry, 84, 1-12, 2007.

Gillon, J. S. and Griffiths, H.: The influence of (photo)respiration on carbon isotope discrimination in plants, Plant Cell Environ., 20, 1217-1230, 1997.

Gleixner, G. and Schmidt, H. L.: Carbon isotope effects on the fructose-1,6-bisphosphate aldolase reaction, origin for nonstatistical C-13 distributions in carbohydrates, J. Biol. Chem., 272, 5382-5387, 1997.

Godbold, D. L., Hoosbeek, M. R., Lukac, M., Cotrufo, M. F., Janssens, I. A., Ceulemans, R., Polle, A., Velthorst, E. J., Scarascia-Mugnozza, G., De Angelis, P., Miglietta, F., and Peressotti, A.: Mycorrhizal hyphal turnover as a dominant process for carbon input into soil organic matter, Plant Soil, 281, 15-24, 2006.

Godin, J. P., Fay, L. B., and Hopfgartner, G.: Liquid chromatography combined with mass Spectrometry for C-13 isotopic analysis in life science research, Mass. Spectrom. Rev., 26, 751-774, 2007.

Goldstein, A. H. and Shaw, S. L.: Isotopes of volatile organic compounds: An emerging approach for studying atmospheric bud- 
gets and chemistry, Chem. Rev., 103, 5025-5048, 2003.

Gordon, J. C. and Larson, P. R.: Seasonal course of photosynthesis respiration and distribution of ${ }^{14} \mathrm{C}$ in young Pinus resinosa trees as related to wood formation, Plant Physiol., 43, 16171624,1968

Gordon, H., Haygarth, P. M., and Bardgett, R. D.: Drying and rewetting effects on soil microbial community composition and nutrient leaching, Soil Biol. Biochem., 40, 302-311, 2008.

Hansen, J. and Beck, E.: The fate and path of assimilation products in the stem of 8-year-old Scots pine (Pinus sylvestris L.) trees, Trees-Struct. Funct., 4, 16-21, 1990.

Hansen, J. and Beck, E.: Seasonal changes in the utilization and turnover of assimilation products in 8-year-old Scots pine (Pinussylvestris L) trees, Trees-Struct. Funct., 8, 172-182, 1994.

Hansen, J., Vogg, G., and Beck, E.: Assimilation, allocation and utilization of carbon by 3-year-old Scots pine (Pinus sylvestris L) trees during winter and early spring, Trees-Struct. Funct., 11, 83-90, 1996.

Hanson, P. J., Edwards, N. T., Garten, C. T., and Andrews, J. A.: Separating root and soil microbial contributions to soil respiration: A review of methods and observations, Biogeochemistry, 48, 115-146, 2000.

Hari, P., Nygren, P., and Korpilahti, E.: Internal circulation of carbon within a tree, Can. J. Forest Res., 21, 514-515, 1991.

Hatch, M. D., Agostino, A., and Jenkins, C.: Measurement of the leakage of $\mathrm{CO}_{2}$ from bundle-sheath cells of leaves during $\mathrm{C}_{4}$ photosynthesis, Plant Physiol., 108, 173-181, 1995.

Hayes, J. M.: Fractionation of Carbon and Hydrogen Isotopes in Biosynthetic Processes, Rev. Mineral. Geochem., 43, 225-277, 2001.

Heinemeyer, A., Hartley, I. P., Evans, S. P., De la Fuente, J. A. C., and Ineson, P.: Forest soil $\mathrm{CO}_{2}$ flux: uncovering the contribution and environmental responses of ectomycorrhizas, Glob. Change Biol., 13, 1786-1797, 2007.

Heinemeyer, A., Wilkinson, M., Vargas, R., Subke, J.-A., Casella, E., Morison, J. I. L., and Ineson, P.: Exploring the "overflow tap" theory: linking forest soil $\mathrm{CO}_{2}$ fluxes and individual mycorrhizosphere components to photosynthesis, Biogeosciences Discuss., 8, 3155-3201, doi:10.5194/bgd-8-3155-2011, 2011.

Heizmann, U., Kreuzwieser, J., Schnitzler, J.-P., Brüggemann, N., and Rennenberg, H.: Assimilate transport in the xylem sap of pedunculate oak (Quercus robur) saplings, Plant Biol., 3, 132138, 2001.

Helle, G. and Schleser, G. H.: Beyond $\mathrm{CO}_{2}$-fixation by Rubisco ? an interpretation of ${ }^{13} \mathrm{C} /{ }^{12} \mathrm{C}$ variations in tree rings from novel intra-seasonal studies on broad-leaf trees, Plant Cell Environ., 27, 367-380, 2004.

Hibbard, K. A., Law, B. E., Reichstein, M., and Sulzman, J.: An analysis of soil respiration across northern hemisphere temperate ecosystems, Biogeochemistry, 73, 29-70, 2005.

Hobbie, E. A. and Werner, R. A.: Intramolecular, compoundspecific, and bulk carbon isotope patterns in C-3 and C-4 plants: A review and synthesis, New Phytol., 161, 371-385, 2004.

Hoch, G. and Keel, S. G.: C-13 labelling reveals different contributions of photoassimilates from infructescences for fruiting in two temperate forest tree species, Plant Biol., 8, 606-614, 2006.

Högberg, M. N. and Högberg, P.: Extramatrical ectomycorrhizal mycelium contributes one-third of microbial biomass and produces, together with associated roots, half the dissolved organic carbon in a forest soil, New Phytol., 154, 791-795, 2002.

Högberg, P. and Read, D. J.: Towards a more plant physiological perspective on soil ecology, Trends Ecol. Evol., 21, 548-554, 2006.

Högberg, P., Nordgren, A., Buchmann, N., Taylor, A. F. S., Ekblad, A., Högberg, M. N., Nyberg, G., Ottosson-Lofvenius, M., and Read, D. J.: Large-scale forest girdling shows that current photosynthesis drives soil respiration, Nature, 411, 789-792, 2001.

Högberg, P., Bhupinderpal, S., Löfvenius, M. O., and Nordgren, A.: Partitioning of soil respiration into its autotrophic and heterotrophic components by means of tree-girdling in old boreal spruce forest, Forest Ecol. Manag., 257, 1764-1767, 2009.

Högberg, M. N., Briones, M. J. I., Keel, S. G., Metcalfe, D. B., Campbell, C., Midwood, A. J., Thornton, B., Hurry, V., Linder, S., Näsholm, T., and Högberg, P.: Quantification of effects of season and nitrogen supply on tree belowground carbon transfer to ectomycorrhizal fungi and other soil organisms in boreal pine forest, New Phytol., 187, 485-493, 2010.

Horwath, W. R., Pregitzer, K. S., and Paul, E. A.: ${ }^{14} \mathrm{C}$ allocation in tree-soil systems, Tree Physiol., 14 1163-1176, 1994.

Hu, J., Moore, D. J. P., and Monson, R. K.: Weather and climate controls over the seasonal carbon isotope dynamics of sugars from subalpine forest trees, Plant Cell Environ., 33, 35-47, 2010.

Hut, G.: Consultants' Group Meeting on Stable Isotope Reference Samples for Geochemical and Hydrological Investigations Vienna, 16-18 September 1985, Report to Director General, International Atomic Energy Agency, Vienna, 42 pp., 1987.

Huygens, D., Denef, K., Vandeweyer, R., Godoy, R., Van Cleemput, O., and Boeckx, P.: Do nitrogen isotope patterns reflect microbial colonization of soil organic matter fractions?, Biol. Fertil. Soil., 44, 955-964, 2008.

Hymus, G. J., Maseyk, K., Valentini, R., and Yakir, D.: Large daily variation in C-13-enrichment of leaf-respired $\mathrm{CO}_{2}$ in two Quercus forest canopies, New Phytol., 167, 377-384, 2005.

Iannone, R., Koppmann, R., and Rudolph, J.: Stable carbon kinetic isotope effects for the production of methacrolein and methyl vinyl ketone from the gas-phase reactions of isoprene with ozone and hydroxyl radicals, Atmos. Environ., 44, 4135-4141, 2010.

IPCC: Climate Change 2007: The Physical Science Basis, Contribution of Working Group I to the Fourth Assessment Report of the Intergovernmental Panel on Climate Change, edited by: Solomon, S., Qin, D., Manning, M., Chen, Z., Marquis, M., Averyt, K. B., Tignor, M., and Miller, H. L., Cambridge University Press, Cambridge, UK, and New York, NY, USA, 996 pp., 2007. Igamberdiev, A. U., Mikkelsen, T. N., Ambus, P., Bauwe, H., Lea, P. J., and Gardestrom, P.: Photorespiration contributes to stomatal regulation and carbon isotope fractionation: A study with barley, potato and arabidopsis plants deficient in glycine decarboxylase, Photosynth. Res., 81, 139-152, 2004.

Janssens, I. A., Lankreijer, H., Matteucci, G., Kowalski, A. S., Buchmann, N., Epron, D., Pilegaard, K., Kutsch, W., Longdoz, B., Grunwald, T., Montagnani, L., Dore, S., Rebmann, C., Moors, E. J., Grelle, A., Rannik, U., Morgenstern, K., Oltchev, S., Clement, R., Gudmundsson, J., Minerbi, S., Berbigier, P., Ibrom, A., Moncrieff, J., Aubinet, M., Bernhofer, C., Jensen, N. O., Vesala, T., Granier, A., Schulze, E. D., Lindroth, A., Dolman, A. J., Jarvis, P. G., Ceulemans, R., and Valentini, R.: Productivity overshadows temperature in determining soil and ecosystem respiration across European forests, Glob. Change Biol., 7, 269- 
$278,2001$.

Janssens, I. A., Dieleman, W., Luyssaert, S., Subke, J. A., Reichstein, M., Ceulemans, R., Ciais, P., Dolman, A. J., Grace, J., Matteucci, G., Papale, D., Piao, S. L., Schulze, E. D., Tang, J., and Law, B. E.: Reduction of forest soil respiration in response to nitrogen deposition, Nat. Geosci., 3, 315-322, 2010.

Johnson, D., Leake, J. R., Ostle, N., Ineson, P., and Read, D. J.: In situ $\left(\mathrm{CO}_{2}\right)-\mathrm{C}-13$ pulse-labelling of upland grassland demonstrates a rapid pathway of carbon flux from arbuscular mycorrhizal mycelia to the soil, New Phytol., 153, 327-334, 2002.

Jones, D. L., Nguyen, C., and Finlay, R. D.: Carbon flow in the rhizosphere: carbon trading at the soil-root interface, Plant Soil, 321, 5-33, 2009.

Joslin, J. D., Gaudinski, J. B., Torn, M. S., Riley, W. J., and Hanson, P. J.: Fine-root turnover patterns and their relationship to root diameter and soil depth in a ${ }^{14} \mathrm{C}$-labeled hardwood forest, New Phytol., 172, 523-535, 2006.

Kagawa, A., Sugimoto, A., and Maximov, T. C.: Seasonal course of translocation, storage and remobilization of ${ }^{13} \mathrm{C}$ pulse-labeled photoassimilate in naturally growing Larix gmelinii saplings, New Phytol., 171, 793-804, 2006a.

Kagawa, A., Sugimoto, A., and Maximov, T. C.: $\left(\mathrm{CO}_{2}\right)-\mathrm{C}-13$ pulselabelling of photoassimilates reveals carbon allocation within and between tree rings, 29, 1571-1584, 2006b.

Kalbitz, K., Solinger, S., Park, J.-H., Michalzik, B., and Matzner, E.: Controls on the Dynamics of Dissolved Organic Matter in Soils: A Review, Soil Sci., 165, 277-304, 2000.

Kaštovská, E. and Šantrûčková, H.: Fate and dynamics of recently fixed $\mathrm{C}$ in pasture plant-soil system under field conditions, Plant Soil, 300, 61-69, 2007.

Kayler, Z. E., Sulzman, E. W., Marshall, J. D., Mix, A., Rugh, W. D., and Bond, B. J.: A laboratory comparison of two methods used to estimate the isotopic composition of soil $\delta^{13} \mathrm{CO}_{2}$ efflux at steady state, Rapid Commun. Mass Spectrom., 22, 2533-2538, 2008.

Kayler, Z., Gessler, A., and Buchmann, N.: What is the speed of link between aboveground and belowground processes?, New Phytol., 187, 886-888, 2010a.

Kayler, Z. E., Sulzman, E. W., Rugh, W. D., Mix, A. C., and Bond, B. J.: Characterizing the impact of diffusive and advective soil gas transport on the measurement and interpretation of the isotopic signal of soil respiration, Soil Biol. Biochem., 42, 435-444, 2010 b.

Kayler, Z., Ganio, L., Hauck, M., Pypker, T., Sulzman, E., Mix, A., and Bond, B.: Bias and uncertainty of $\delta^{13} \mathrm{CO}_{2}$ isotopic mixing models, Oecologia, 163, 227-234, 2010c.

Kayler, Z. E., Kaiser, M., Gessler, A., Ellerbrock, R. H., and Sommer, M.: Application of $\delta^{13} \mathrm{C}$ and $\delta^{15} \mathrm{~N}$ isotopic signatures of organic matter fractions sequentially separated from adjacent arable and forest soils to identify carbon stabilization mechanisms, Biogeosciences, 8, 2895-2906, doi:10.5194/bg-8-28952011, 2011.

Keel, S. G. and Schädel, C.: Expanding leaves of mature deciduous forest trees rapidly become autotrophic, Tree Physiol., 30, 1253 1259,2010

Keel, S. G., Siegwolf, R. T. W., and Körner, C.: Canopy $\mathrm{CO}_{2}$ enrichment permits tracing the fate of recently assimilated carbon in a mature deciduous forest, New Phytol., 172, 319-329, 2006.

Keel, S. G., Siegwolf, R. T. W., Jäggi, M., and Körner, C.: Rapid mixing between old and new $\mathrm{C}$ pools in the canopy of mature forest trees, Plant Cell Environ., 30, 963-972, 2007.

Keitel, C., Matzarakis, A., Rennenberg, H., and Gessler, A.: Carbon isotopic composition and oxygen isotopic enrichment in phloem and total leaf organic matter of european beech (Fagus sylvatica L.) along a climate gradient, Plant Cell Environ., 29, 1492-1507, 2006.

Keppler, F., Kalin, R. M., Harper, D. B., McRoberts, W. C., and Hamilton, J. T. G.: Carbon isotope anomaly in the major plant $\mathrm{C}_{1}$ pool and its global biogeochemical implications, Biogeosciences, 1, 123-131, doi:10.5194/bg-1-123-2004, 2004.

Kindler, R., Siemens, J., Kaiser, K., Walmsley, D. C., Bernhofer, C., Buchmann, N., Cellier, P., Eugster, W., Gleixner, G., Grunwald, T., Heim, A., Ibrom, A., Jones, S. K., Jones, M., Klumpp, K., Kutsch, W., Larsen, K. S., Lehuger, S., Loubet, B., McKenzie, R., Moors, E., Osborne, B., Pilegaard, K., Rebmann, C., Saunders, M., Schmidt, M. W. I., Schrumpf, M., Seyfferth, J., Skiba, U., Soussana, J. F., Sutton, M. A., Tefs, C., Vowinckel, B., Zeeman, M. J., and Kaupenjohann, M.: Dissolved carbon leaching from soil is a crucial component of the net ecosystem carbon balance, Glob. Change Biol., 17, 1167-1185, 2011.

Kleber, M., Mikutta, R., Torn, M. S., and Jahn, R.: Poorly crystalline mineral phases protect organic matter in acid subsoil horizons, Eur. J. Soil Sci., 56, 717-725, 2005.

Kleber, M., Sollins, P., and Sutton, R.: A conceptual model of organo-mineral interactions in soils: self-assembly of organic molecular fragments into zonal structures on mineral surfaces, Biogeochemistry, 85, 9-24, 2007.

Kleber, M., Nico, P. S., Plante, A., Filley, T., Kramer, M., Swanston, C., and Sollins, P.: Old and stable soil organic matter is not necessarily chemically recalcitrant: implications for modeling concepts and temperature sensitivity, Glob. Change Biol., 17, 10971107, 2011.

Knohl, A., Werner, R. A., Brand, W. A., and Buchmann, N.: Shortterm variations in $\delta^{13} \mathrm{C}$ of ecosystem respiration reveals link between assimilation and respiration in a deciduous forest, Oecologia, 142, 70-82, 2005.

Kodama, N., Barnard, R., Salmon, Y., Weston, C., Ferrio, J. P., Holst, J., Werner, R., Sauer, M., Eugster, W., Buchmann, N., and Gessler, A.: Temporal dynamics of the carbon isotope composition in a Pinus sylvestris stand - from newly assimilated organic carbon to respired $\mathrm{CO}_{2}$, Oecologia, 156, 737-750, 2008.

Kodama, N., Ferrio, J. P., Brüggemann, N., and Gessler, A.: Shortterm dynamics of the carbon isotope composition of $\mathrm{co} 2$ emitted from a wheat agroecosystem - physiological and environmental controls, Plant Biol., 13, 115-125, 2011.

Koehler, B., Zehe, E., Corre, M. D., and Veldkamp, E.: An inverse analysis reveals limitations of the soil- $\mathrm{CO}_{2}$ profile method to calculate $\mathrm{CO}_{2}$ production and efflux for well-structured soils, Biogeosciences, 7, 2311-2325, doi:10.5194/bg-7-2311-2010, 2010.

Korol, R. L., Kirschbaum, M. U. F., Farquhar, G. D., and Jeffreys, M.: Effects of water status and soil fertility on the C-isotope signature in Pinus radiata, Tree Physiol., 19, 551-562, 1999.

Kozlowski, T. T.: Growth and development of trees, Academic Press, New York, 1971.

Kozlowski, T. T.: Carbohydrates sources and sinks in woody plants, Bot. Rev., 58, 107-222, 1992.

Kramer, C., Trumbore, S., Fröberg, M., Cisneros Dozal, L. M., Zhang, D., Xu, X., Santos, G. M., and Hanson, P. J.: Recent 
( $<4$ year old) leaf litter is not a major source of microbial carbon in a temperate forest mineral soil, Soil Biol. Biochem., 42, 1028-1037, 2010.

Kreuzwieser, J., Graus, M., Wisthaler, A., Hansel, A., Rennenberg, H., and Schnitzler, J.-P.: Xylem-transported glucose as an additional carbon source for leaf isoprene formation in Quercus robur, New Phytol., 156, 171-178, 2002.

Kuptz, D., Fleischmann, F., Matyssek, R., and Grams, T. E. E.: Seasonal pattern of carbon allocation to respiratory pools in 60yr-old deciduous (Fagus sylvatica) and evergreen (Picea abies) trees assessed via whole-tree stable carbon isotope labeling, New Phytol., 191, 160-172, 2011a.

Kuptz, D., Matyssek, R., and Grams, T. E. E.: Seasonal dynamics in the stable carbon isotope composition $\left(\delta^{13} \mathrm{C}\right)$ from non-leafy branch, trunk and coarse root $\mathrm{CO}_{2}$ efflux of adult deciduous ( $\mathrm{Fa}$ gus sylvatica) and evergreen (Picea abies) trees, Plant Cell Environ., 34, 363-373, $2011 \mathrm{~b}$.

Kuzyakov, Y.: Sources of $\mathrm{CO}_{2}$ efflux from soil and review of partitioning methods, Soil Biol. Biochem., 38, 425-448, 2006.

Kuzyakov, Y. and Domanski, G.: Carbon input by plants into the soil, Review, J. Plant Nutr. Soil Sc., 163, 421-431, 2000.

Kuzyakov, Y. and Cheng, W.: Photosynthesis controls of rhizosphere respiration and organic matter decomposition, Soil Biol. Biochem., 33, 1915-1925, 2001.

Kuzyakov, Y. and Gavrichkova, O.: Time lag between photosynthesis and carbon dioxide efflux from soil: a review of mechanisms and controls, Glob. Change Biol., 16, 3386-3406, 2010.

Kuzyakov, Y., Friedel, J. K., and Stahr, K.: Review of mechanisms and quantification of priming effects, Soil Biol. Biochem., 32, 1485-1498, 2000.

Lacointe, A., Kajji, A., Daudet, F. A., Archer, P., and Frossard, J. S.: Mobilization of carbon reserves in young walnut trees, Acta Bot. Gallica, 140, 435-441, 1993.

Lacointe, A., Deleens, E., Ameglio, T., Saint-Joanis, B., Lelarge, C., Vandame, M., Song, G. C., and Daudet, F. A.: Testing the branch autonomy theory: a ${ }^{13} \mathrm{C} /{ }^{14} \mathrm{C}$ double-labelling experiment on differentially shaded branches, Plant Cell Environ., 27, 11591168, 2004.

Lamade, E., Setiyo, I. E., Girard, S., and Ghashghaie, J.: Changes in ${ }^{13} \mathrm{C} /{ }^{12} \mathrm{C}$ of oil palm leaves to understand carbon use during their passage from heterotrophy to autotrophy, Rapid Commun. Mass Spectrom., 23, 2586-2596, 2009.

Lang, A.: A relay mechanism for phloem transport, Ann. Bot., 44, 141-145, 1979.

Larcher, W.: Physiological plant ecology, Springer, Berlin, Germany, 513 pp., 2003.

Lattanzi, F. A., Schnyder, H., and Thornton, B.: The sources of carbon and nitrogen supplying leaf growth. Assessment of the role of stores with compartmental models, Plant Physiol., 137, 383-395, 2005.

Leake, J. R., Ostle, N. J., Rangel-Castro, J. I., and Johnson, D.: Carbon fluxes from plants through soil organisms determined by field $\left(\mathrm{CO}_{2}\right)$-C-13 pulse-labelling in an upland grassland, Appl. Soil Ecol., 33, 152-175, 2006.

Leavitt, S. W. and Long, A.: Stable-carbon isotope variability in tree foliage and wood, Ecology, 67, 1002-1010, 1986.

Lee, D. R.: Synchronized pressure-potential changes in the phloem of Fraxinus americana L., Planta, 151, 304-308, 1981.

Lehmeier, C., Lattanzi, F., Schäufele, R., Wild, M., and Schnyder,
H.: Root and shoot respiration of perennial ryegrass are supplied by the same substrate pools: Assessment by dynamic ${ }^{13} \mathrm{C}$ labeling and compartmental analysis of tracer kinetics, Plant Physiol., 148, 1148-1158, 2008.

Lehmeier, C. A., Lattanzi, F. A., Schäufele, R., and Schnyder, H.: Nitrogen deficiency increases the residence time of respiratory carbon in the respiratory substrate supply system of perennial ryegrass, Plant Cell Environ., 33, 76-87, 2010.

Lerch, T., Nunan, N., Dignac, M. F., Chenu, C., and Mariotti, A.: Variations in microbial isotopic fractionation during soil organic matter decomposition, Biogeochemistry, 106, 5-21, 2011.

Lewicki, J. L., Evans, W. C., Hilley, G. E., Sorey, M. L., Rogie, J. D., and Brantley, S. L.: Shallow soil CO2 flow along the San Andreas and Calaveras Faults, California, J. Geophys. Res.-Solid Earth, 108, 2187, doi:10.1029/2002JB002141, 2003.

Levy, P. E., Meir, P., Allen, S. J., and Jarvis P. G.: The effect of aqueous transport of $\mathrm{CO}_{2}$ in xylem sap on gas exchange in woody plants, Tree Physiol., 19, 53-58, 1999.

Liski, J., Perruchoud, D., and Karjalainen, T.: Increasing carbon stocks in the forest soils of western Europe, Forest Ecol. Manag., 169, 159-175, 2002.

Livingston, G. P., Hutchinson, G. L., and Spartalian, K.: Diffusion theory improves chamber-based measurements of trace gas emissions, Geophys. Res. Lett., 32, L24817, doi:10.1029/2005GL024744, 2005.

Loreto, F. and Schnitzler, J.-P.: Abiotic stresses and induced BVOCs, Trends Plant Sci., 15, 154-166, 2010.

Lusk, C. H. and Piper, F. I.: Seedling size influences relationships of shade tolerance with carbohydrate-storage patterns in a temperate rainforest, Funct. Ecol., 21, 78-86, 2007.

Lüttge, U.: Ecophysiology of Crassulacean Acid Metabolism (CAM), Ann. Bot., 93, 629-652, 2004.

Lützow, M. v., Kögel-Knabner, I., Ekschmitt, K., Matzner, E., Guggenberger, G., Marschner, B., and Flessa, H.: Stabilization of organic matter in temperate soils: mechanisms and their relevance under different soil conditions - a review, Eur. J. Soil Sci., 57, 426-445, 2006.

Marin-Spiotta, E., Silver, W. L., Swanston, C. W., and Ostertag, R.: Soil organic matter dynamics during 80 years of reforestation of tropical pastures, Glob. Change Biol., 15, 1584-1597, 2009.

Martin, T. A., Teskey, R. O., and Dougherty, P. M.: Movement of respiratory $\mathrm{CO}_{2}$ in stems of loblolly pine (Pinus taeda L.) seedlings, Tree Physiol., 14, 481-495, 1994.

Maunoury, F., Berveiller, D., Lelarge, C., Pontailler, J. Y., Vanbostal, L., and Damesin, C.: Seasonal, daily and diurnal variations in the stable carbon isotope composition of carbon dioxide respired by tree trunks in a deciduous oak forest, Oecologia, 151, 268-279, 2007.

Mayrhofer, S., Heizmann, U., Magel, E., Eiblmeier, M., Müller, A., Rennenberg, H., Hampp, R., Schnitzler, J.-P., and Kreuzwieser, $\mathrm{J} .:$ Carbon balance in leaves of young poplar trees, Plant Biol., 6, 730-739, 2004.

McCarroll, D. and Pawellek, F.: Stable carbon isotope ratios of Pinus sylvestris from northern Finland and the potential for extracting a climate signal from long Fennoscandian chronologies, Holocene, 11, 517-526, 2001.

McGuire, M. A., Marshall, J. D., and Teskey, R. O.: Assimilation of xylem-transported ${ }^{13} \mathrm{C}$-labelled $\mathrm{CO}_{2}$ in leaves and branches of sycamore (Platanus occidentalis L.), J. Exp. Bot., 60, 3809- 
$3817,2009$.

Meharg, A. A.: A critical review of labeling techniques used to quantify rhizosphere carbon flow, Plant Soil, 166, 55-62, 1994.

Melzer, E. and Schmidt, H. L.: Carbon isotope effects on the pyruvate-dehydrogenase reaction and their importance for relative C-13 depletion in lipids, J. Biol. Chem., 262, 8159-8164, 1987.

Mencuccini, M. and Hölttä, T.: The significance of phloem transport for the speed with which canopy photosynthesis and belowground respiration are linked, New Phytol., 185, 189-203, 2010.

Mikutta, R., Kleber, M., Torn, M., and Jahn, R.: Stabilization of Soil Organic Matter: Association with Minerals or Chemical Recalcitrance?, Biogeochemistry, 77, 25-56, 2006.

Millard, P., Sommerkorn, M., and Grelet, G. A.: Environmental change and carbon limitation in trees: a biochemical, ecophysiological and ecosystem appraisal, New Phytol., 175, 11-28, 2007.

Millard, P., Midwood, A. J., Hunt, J. E., Barbour, M. M., and Whitehead, D.: Quantifying the contribution of soil organic matter turnover to forest soil respiration, using natural abundance $\delta^{13} \mathrm{C}$, Soil Biol. Biochem., 42, 935-943, 2010.

Miltner, A., Richnow, H.-H., Kopinke, F.-D., and Kästner, M.: Assimilation of $\mathrm{CO}_{2}$ by soil microorganisms and transformation into soil organic matter, Org. Geochem., 35, 1015-1024, 2004.

Miltner, A., Richnow, H.-H., Kopinke, F.-D., and Kästner, M.: Incorporation of carbon originating from $\mathrm{CO}_{2}$ into different compounds of soil microbial biomass and soil organic matter, Isot. Environ. Healt. S., 41, 135-140, 2005.

Minchin, P. E. H. and Thorpe, M. R.: Measurement of unloading and reloading of photo-assimilate within the stem of bean, J. Exp. Bot., 38, 211-220, 1987.

Mook, W. G., Bommerson, J. C., and Staverman, W. H.: Carbon isotope fractionations between dissolved bicarbonate and gaseous carbon dioxide, Earth Planet. Sci. Lett. 22, 169-76, 1974.

Moore, D. J. P., Gonzalez-Meler, M. A., Taneva, L., Pippen, J. S., Kim, H. S., and DeLucia, E. H.: The effect of carbon dioxide enrichment on apparent stem respiration from Pinus taeda L. is confounded by high levels of soil carbon dioxide, Oecologia, 158, 1-10, 2008.

Mor, Y. and Halevy, A. H.: Translocation of ${ }^{14} \mathrm{C}$-assimilates in roses 1. Effect of the age of the shoot and the location of the source leaf, Physiol. Plant., 45, 177-182, 1979.

Mordacq, L., Mousseau, M., and Deleens, E.: A ${ }^{13} \mathrm{C}$ method of estimation of carbon allocation to roots in a young chestnut coppice, Plant Cell Environ., 9, 735-739, 1986.

Mortazavi, B., Chanton, J. P., Prater, J. L., Oishi, A. C., Oren, R., and Katul, G.: Temporal variability in ${ }^{13} \mathrm{C}$ of respired $\mathrm{CO}_{2}$ in a pine and a hardwood forest subject to similar climatic conditions, Oecologia, 142, 57-69, 2005.

Moyano, F. E., Kutsch, W. L., and Schulze, E. D.: Response of mycorrhizal, rhizosphere and soil basal respiration to temperature and photosynthesis in a barley field, Soil Biol. Biochem., 39, 843-853, 2007.

Moyano, F. E., Kutsch, W. L., and Rebmann, C.: Soil respiration fluxes in relation to photosynthetic activity in broad-leaf and needle-leaf forest stands, Agr. Forest Meteorol., 148, 135-143, 2008.

Moyes, A. B., Gaines, S. J., Siegwolf, R. T. W., and Bowling, D. R.: Diffusive fractionation complicates isotopic partitioning of autotrophic and heterotrophic sources of soil respiration, Plant Cell Environ., 33, 1804-1819, 2010.

Müller, M., Alewell, C., and Hagedorn, F.: Effective retention of litter-derived dissolved organic carbon in organic layers, Soil Biol. Biochem., 41, 1066-1074, 2009.

Münch, E.: Die Stoffbewegung in der Pflanze, Fischer, Jena, Germany, 1930.

Nadelhoffer, K. F. and Fry, B.: Controls on natural N-15 and C-13 abundances in forest soil organic-matter, Soil Sci. Soc. Am. J., 52, 1633-1640, 1988.

Nickerson, N. and Risk, D.: Physical controls on the isotopic composition of soil-respired $\mathrm{CO}_{2}$, J. Geophys. Res., 114, G01013, doi:10.1029/2008JG000766, 2009a.

Nickerson, N. and Risk, D.: Keeling plots are non-linear in nonsteady state diffusive environments, Geophys. Res. Lett., 36, L08401, doi:10.1029/2008GL036945, 2009b.

Nogués, S., Tcherkez, G., Cornic, G., and Ghashghaie, J.: Respiratory carbon metabolism following illumination in intact French bean leaves using C-13/C-12 isotope labeling, Plant Physiol., 136, 3245-3254, 2004.

Nogués, S., Damesin, C., Tcherkez, G., Maunoury, F., Cornic, G., and Ghashghaie, J.: C-13/C-12 isotope labelling to study leaf carbon respiration and allocation in twigs of field-grown beech trees, Rapid Commun. Mass Spectrom., 20, 219-226, 2006.

Nöh, K., Grönke, K., Luo, B., Takors, R., Oldiges, M., and Wiechert, W.: Metabolic flux analysis at ultra-short time scale: Isotopically non-stationary ${ }^{13} \mathrm{C}$ labeling experiments, J. Biotechnol., 129, 249-267, 2007.

Nottingham, A. T., Turner, B. L., Winter, K., van der Heijden, M. G. A., and Tanner, E. V. J.: Arbuscular mycorrhizal mycelial respiration in a moist tropical forest, New Phytol., 186, 957-967, 2010.

Ocio, J. A., Brookes, P. C., and Jenkinson, D. S.: Field incorporation of straw and its effects on soil microbial biomass and soil inorganic N, Soil Biol. Biochem., 23, 171-176, 1991.

Offermann, C., Ferrio, J. P., Holst, J., Grote, R., Siegwolf, R., Kayler, Z., Gessler, A.: The long way down - Are carbon and oxygen isotope signals in the tree ring uncoupled from canopy physiological processes?, Tree Physiol., 31, 1088-1102, 2011.

O'Leary, M. H.: Carbon isotopes in photosynthesis, BioScience, 38, 325-336, 1988.

Olsrud, M. and Christensen, T. R.: Carbon cycling in subarctic tundra; seasonal variation in ecosystem partitioning based on in situ ${ }^{14} \mathrm{C}$ pulse-labelling, Soil Biol. Biochem., 36, 245-253, 2004.

Olsson, P., Linder, S., Giesler, R., and Högberg, P.: Fertilization of boreal forest reduces both autotrophic and heterotrophic soil respiration, Glob. Change Biol., 11, 1745-1753, 2005.

Osmond, C.: Crassulacean Acid Metabolism - Curiosity in Context, Ann. Rev. Plant Physiol. Plant Mol. Biol., 29, 379-414, 1978.

Osono, T., Takeda, H., and Azuma, J.-I.: Carbon isotope dynamics during leaf litter decomposition with reference to lignin fractions, Ecol. Res., 23, 51-55, 2008.

Ostle, N., Whiteley, A. S., Bailey, M. J., Sleep, D., Ineson, P., and Manefield, M.: Active microbial RNA turnover in a grassland soil estimated using a $\left(\mathrm{CO}_{2}\right)-\mathrm{C}-13$ spike, Soil Biol. Biochem., 35, 877-885, 2003.

Ostle, N., Briones, M. J. I., Ineson, P., Cole, L., Staddon, P., and Sleep, D.: Isotopic detection of recent photosynthate carbon flow into grassland rhizosphere fauna, Soil Biol. Biochem., 39, 768- 
777, 2007.

Palacio, S., Paterson, E., Sim, A., Hester, A. J., and Millard, P.: Browsing effects on intra-ring $\mathrm{C}$ allocation in species with contrasting wood anatomy, Tree Physiol., 31, 150-159, 2011.

Paterson, E., Midwood, A. J., and Millard, P.: Through the eye of the needle: a review of isotope approaches to quantify microbial processes mediating soil carbon balance, New Phytol., 184, 1933, 2009.

Paul, M. J. and Foyer, C. H.: Sink regulation of photosynthesis, J. Exp. Bot., 52, 1383-1400, 2001.

Peñuelas, J. and Staudt, M.: BVOCs and global change, Trends Plant Sci., 15, 133-144, 2010.

Pfanz, H., Aschan, G., Langenfeld-Heyser, R., Wittmann, C., and Loose, M.: Ecology and ecophysiology of tree stems: corticular and wood photosynthesis, Naturwissenschaften, 89, 147-162, 2002.

Phillips, C. L., Nickerson, N., Risk, D., Kayler, Z. E., Andersen, C., Mix, A., and Bond, B. J.: Soil moisture effects on the carbon isotope composition of soil respiration, Rapid Commun. Mass Spectrom., 24, 1271-1280, 2010.

Phillips, C. L., Nickerson, N., Risk, D., and Bond, B. J.: Interpreting diel hysteresis between soil respiration and temperature, Glob. Change Biol., 17, 515-527, 2011.

Plain, C., Gerant, D., Maillard, P., Dannoura, M., Dong, Y., Zeller, B., Priault, P., Parent, F., and Epron, D.: Tracing of recently assimilated carbon in respiration at high temporal resolution in the field with a tunable diode laser absorption spectrometer after in situ ${ }^{13} \mathrm{CO}_{2}$ pulse labelling of 20 -year-old beech trees, Tree Physiol., 29 1433-1445, 2009.

Plante, A. F., Conant, R. T., Stewart, C. E., Paustian, K., and Six, J.: Impact of Soil Texture on the Distribution of Soil Organic Matter in Physical and Chemical Fractions, Soil Sci. Soc. Am. J., 70, 287-296, 2006.

Poulsen, T. G. and Møldrup, P.: Evaluating effects of wind-induced pressure fluctuations on soil-atmosphere gas exchange at a landfill using stochastic modeling, Waste Manage. Res., 24, 473-481, 2006.

Preston, C., Nault, J., and Trofymow, J.: Chemical Changes During 6 Years of Decomposition of 11 Litters in Some Canadian Forest Sites. Part 2. $\delta^{13} \mathrm{C}$ Abundance, Solid-State $\delta^{13} \mathrm{C}$ NMR Spectroscopy and the Meaning of "Lignin", Ecosystems, 12, 10781102, 2009.

Priault, P., Wegener, F., and Werner, C.: Pronounced differences in diurnal variation of carbon isotope composition of leaf respired $\mathrm{CO}_{2}$ among functional groups, New Phytol., 181, 400-412, 2009.

Randerson, J. T., Collatz, G. J., Fessenden, J. E., Munoz, A. D., Still, C. J., Berry, J. A., Fung, I. Y., Suits, N., and Denning, A. S.: A possible global covariance between terrestrial gross primary production and ${ }^{13} \mathrm{C}$ discrimination: Consequences for the atmospheric ${ }^{13} \mathrm{C}$ budget and its response to ENSO, Global Biogeochem. Cy., 16, 1136, doi:10.1029/2001GB001845, 2002.

Rendina, A. R., Hermes, J. D., and Cleland, W. W.: Use of multiple isotope effects to study the mechanism of 6-phosphogluconate dehydrogenase, Biochemistry, 23, 6257-6262, 1984.

Resurreccion, A. C., Moldrup, P., Kawamoto, K., Yoshikawa, S., Rolston, D. E., and Komatsu, T.: Variable Pore Connectivity Factor Model for Gas Diffusivity in Unsaturated, Aggregated Soil, Vadose Zone J., 7, 397-405, 2008.
Richter, A., Wanek, W., Werner, R. A., Ghashghaie, J., Jaggi, M., Gessler, A., Brugnoli, E., Hettmann, E., Göttlicher, S. G., Salmon, Y., Bathellier, C., Kodama, N., Nogués, S., Soe, A., Volders, F., Sorgel, K., Blochl, A., Siegwolf, R. T. W., Buchmann, N., and Gleixner, G.: Preparation of starch and soluble sugars of plant material for the analysis of carbon isotope composition: A comparison of methods, Rapid Commun. Mass Spectrom., 23, 2476-2488, 2009.

Rocha, A. V., Goulden, M. L., Dunn, A. L., and Wofsy, S. C.: On linking interannual tree ring variability with observations of whole-forest $\mathrm{CO}_{2}$ flux, Glob. Change Biol., 12, 1378-1389, 2006.

Rolland, F., Baena-Gonzalez, E., and Sheen, J.: Sugar sensing and signaling in plants: Conserved and novel mechanisms, Annu. Rev. Plant Biol., 57, 675-709, 2006.

Rossmann, A., Butzenlechner, M., and Schmidt, H. L.: Evidence for a nonstatistical carbon isotope distribution in natural glucose, Plant Physiol., 96, 609-614, 1991.

Rubino, M., Dungait, J. A. J., Evershed, R. P., Bertolini, T., De Angelis, P., D’Onofrio, A., Lagomarsino, A., Lubritto, C., Merola, A., Terrasi, F., and Cotrufo, M. F.: Carbon input belowground is the major $\mathrm{C}$ flux contributing to leaf litter mass loss: Evidences from a ${ }^{13} \mathrm{C}$ labelled-leaf litter experiment, Soil Biol. Biochem., 42, 1009-1016, 2010.

Rudolph, J., Anderson, R. S., Czapiewski, K. V., Czuba, E., Ernst, D., Gillespie, T., Huang, L., Rigby, C., and Thompson, A. E.: The stable carbon isotope ratio of biogenic emissions of isoprene and the potential use of stable isotope ratio measurements to study photochemical processing of isoprene in the atmosphere, J. Atmos. Chem., 44, 39-55, 2003.

Ruehr, N. K., Offermann, C. A., Gessler, A., Winkler, J. B., Ferrio, J. P., Buchmann, N., and Barnard, R. L.: Drought effects on allocation of recent carbon: from beech leaves to soil $\mathrm{CO}_{2}$ efflux, New Phytol., 184, 950-961, 2009.

Salmon, Y., Barnard, R. L., and Buchman, N: Ontogeny and leaf gas exchange mediate the carbon isotopic signature of herbaceous plants, Plant Cell Environ., 34, 465-479, 2011.

Sanderman, J. and Amundson, R.: A comparative study of dissolved organic carbon transport and stabilization in California forest and grassland soils, Biogeochemistry, 89, 309-327, 2008.

Sanderman, J., Baldock, J., and Amundson, R.: Dissolved organic carbon chemistry and dynamics in contrasting forest and grassland soils, Biogeochemistry, 89, 181-198, 2008.

Šantrùèková, H., Bird, M. I., and Lloyd, J.: Microbial processes and carbon-isotope fractionation in tropical and temperate grassland soils, Funct. Ecol., 14, 108-114, 2000.

Scandellari, F., Hobbie, E. A., Ouimette, A. P., and Stucker, V. K.: Tracing metabolic pathways of lipid biosynthesis in ectomycorrhizal fungi from position-specific ${ }^{13} \mathrm{C}$-labelling in glucose, Environ. Microbiol., 11, 3087-3095, 2009.

Scartazza, A., Mata, C., Matteucci, G., Yakir, D., Moscatello, S., and Brugnoli, E.: Comparisons of delta $\mathrm{C}-13$ of photosynthetic products and ecosystem respiratory $\mathrm{CO}_{2}$ and their response to seasonal climate variability, Oecologia, 140, 340-351, 2004.

Schier, G. A.: Seasonal pathways of ${ }^{14} \mathrm{C}$ photosynthate in red pine labeled in May, July and October, For. Sci., 16, 2-13, 1970.

Schimel, J., Balser, T. C., and Wallenstein, M.: Microbial stressresponse physiology and its implication for ecosystem function, Ecology, 88, 1386-1394, 2007. 
Schmidt, H. L.: Fundamentals and systematics of the nonstatistical distributions of isotopes in natural compounds, Naturwissenschaften, 90, 537-552, 2003.

Schmidt, H. L. and Gleixner, G.: Carbon isotope effects on key reactions in plant metabolism and ${ }^{13} \mathrm{C}$-patterns in natural compounds, in: Stable isotopes - integration of biological, ecological and geochemical processes, edited by: Griffiths, H., Bios Scientific Publishers Ltd, Oxford, 13-25, 1998.

Schnitzler, J.-P., Graus, M., Kreuzwieser, J., Heizmann, U., Rennenberg, H., Wisthaler, A., and Hansel, A.: Contribution of different carbon sources to isoprene biosynthesis in poplar leaves, Plant Physiol., 135, 152-160, 2004.

Schnyder, H., Schäufele, R., Lotscher, M., and Gebbing, T.: Disentangling $\mathrm{CO}_{2}$ fluxes: direct measurements of mesocosm-scale natural abundance $\left(\mathrm{CO}_{2}\right)-\mathrm{C}-13 /\left(\mathrm{CO}_{2}\right)-\mathrm{C}-12$ gas exchange, $\mathrm{C}-13$ discrimination, and labelling of $\mathrm{CO}_{2}$ exchange flux components in controlled environments, Plant Cell Environ., 26, 1863-1874, 2003

Schuur, E. A. G. and Trumbore, S. E.: Partitioning sources of soil respiration in boreal black spruce forest using radiocarbon, Glob. Change Biol., 12, 165-176, 2006.

Scott-Denton, L. E., Rosenstiel, T. N., and Monson, R. K.: Differential controls by climate and substrate over the heterotrophic and rhizospheric components of soil respiration, Glob. Change Biol., 12, 205-216, 2006.

Seibt, U., Rajabi, A., Griffiths, H., and Berry, J. A.: Carbon isotopes and water use efficiency: Sense and sensitivity, Oecologia, 155, 441-454, 2008.

Sessions, A. L.: Isotope-ratio detection for gas chromatography, J. Sep. Sci., 29, 1946-1961, 2006.

Severinghaus, J. P., Bender, M. L., Keeling, R. F., and Broecker, W. S.: Fractionation of soil gases by diffusion of water vapor, gravitational settling, and thermal diffusion, Geochim. Cosmochim. Acta, 6, 1005-1018, 1996.

Sharkey, T. D., Loreto, F., Delwiche, C. F., and Treichel, I. W.: Fractionation of carbon isotopes during biogenesis of atmospheric isoprene, Plant Physiol., 97, 463-466, 1991.

Sharkey, T. D., Wiberley, A. E., and Donohue, A. R.: Isoprene emission from plants: why and how, Ann. Bot., 101, 5-18, 2008.

Shiroya, T., Lister, G. R., Slankis, V., Krotkov, G., and Nelson, C. D.: Seasonal changes in respiration photosynthesis and translocation of ${ }^{14} \mathrm{C}$ labelled products of photosynthesis in young Pinus strobus L plants, Ann. Bot., 30, 81-91, 1966.

Six, J. and Jastrow, J. D.: Organic matter turnover, in: Encyclopedia of Soil Science, edited by: Lal, R., Marcel Dekker, New York, 2002.

Skomarkova, M. V., Vaganov, E. A., Mund, M., Knohl, A., Linke, P., Boerner, A., and Schulze, E. D.: Inter-annual and seasonal variability of radial growth, wood density and carbon isotope ratios in tree rings of beech (Fagus sylvatica) growing in Germany and Italy, Trees-Struct. Funct., 20, 571-586, 2006.

Slewinski, T. L. and Braun, D. M.: Current perspectives on the regulation of whole-plant carbohydrate partitioning, Plant Sci., 178, 341-349, 2010.

Smith, J. L. and Paul, E. A.: Use of an in situ labeling technique for the determination of seasonal ${ }^{14} \mathrm{C}$ distribution in Ponderosa pine, Plant Soil, 106, 221-229, 1988.

Sollins, P., Kramer, M., Swanston, C., Lajtha, K., Filley, T., Aufdenkampe, A., Wagai, R., and Bowden, R.: Sequential density fractionation across soils of contrasting mineralogy: evidence for both microbial- and mineral-controlled soil organic matter stabilization, Biogeochemistry, 96, 209-231, 2009.

Staddon, P. L., Ramsey, C. B., Ostle, N., Ineson, P., and Fitter, A. H.: Rapid turnover of hyphae of mycorrhizal fungi determined by AMS microanalysis of C-14, Science, 300, 1138-1140, 2003.

Steinmann, K., Siegwolf, R. T. W., Saurer, M., and Körner, C.: Carbon fluxes to the soil in a mature temperate forest assessed by C-13 isotope tracing, Oecologia, 141, 489-501, 2004.

Stewart, D. P. C. and Metherell, A. K.: ${ }^{13} \mathrm{C}$ uptake and allocation in pasture plants following field pulse-labelling, Plant Soil, 210, 61-73, 1999.

Stringer, J. W. and Kimmerer, T. W.: Refixation of xylem sap $\mathrm{CO}_{2}$ in Populus deltoides, Physiol. Plant., 89, 243-251, 1993.

Subke, J. A. and Bahn, M.: On the "temperature sensitivity" of soil respiration: Can we use the immeasurable to predict the unknown?, Soil Biol. Biochem., 42, 1653-1656, 2010.

Subke, J. A., Inglima, I., and Cotrufo, M. F.: Trends and methodological impacts in soil $\mathrm{CO}_{2}$ efflux partitioning: a metaanalytical review, Glob. Change Biol., 12, 1813-1813, 2006.

Takle, E. S., Brandle, J. R., Schmidt, R. A., Garcia, R., Litvina, I. V., Massman, W. J., Zhou, X., Doyle, G., and Rice, C. W.: Highfrequency pressure variations in the vicinity of a surface $\mathrm{CO}_{2}$ flux chamber, Agr. Forest Meteorol., 114, 245-250, 2003.

Takle, E. S., Massman, W. J., Brandle, J. R., Schmidt, R. A., Zhou, X., Litvina, I. V., Garcia, R., Doyle, G., and Rice, C. W.: Influence of high-frequency ambient pressure pumping on carbon dioxide efflux from soil, Agr. Forest Meteorol., 124, 193-206, 2004.

Tang, J. W., Baldocchi, D. D., and Xu, L.: Tree photosynthesis modulates soil respiration on a diurnal time scale, Glob. Change Biol., 11, 1298-1304, 2005.

Tang, Y. J., Martin, H. G., Myers, S., Rodriguez, S., Baidoo, E. E. K., and Keasling, J. D.: Advances in analysis of microbial metabolic fluxes via ${ }^{13} \mathrm{C}$ isotopic labeling, Mass Spectrom. Rev., 28, 362-375, 2009.

Tcherkez, G.: How large is the carbon isotope fractionation of the photorespiratory enzyme glycine decarboxylase?, Funct. Plant Biol., 33, 911-920, 2006.

Tcherkez, G.: Do metabolic fluxes matter for interpreting isotopic respiratory signals?, New Phytol., 186, 567-568, 2010.

Tcherkez, G. and Farquhar, G. D.: Carbon isotope effect predictions for enzymes involved in the primary carbon metabolism of plant leaves, Funct. Plant Biol., 32, 277-291, 2005.

Tcherkez, G. and Hodges, M.: How stable isotopes may help to elucidate primary nitrogen metabolism and its interaction with (photo)respiration in C-3 leaves, J. Exp. Bot., 59, 1685-1693, 2008.

Tcherkez, G., Nogues, S., Bleton, J., Cornic, G., Badeck, F., and Ghashghaie, J.: Metabolic origin of carbon isotope composition of leaf dark-respired $\mathrm{CO}_{2}$ in French bean, Plant Physiol., 131, 237-244, 2003.

Tcherkez, G., Farquhar, G., Badeck, F., and Ghashghaie, J.: Theoretical considerations about carbon isotope distribution in glucose of C-3 plants, Funct. Plant Biol., 31, 857-877, 2004.

Teece, M. A., Fogel, M. L., Dollhopf, M. E., and Nealson, K. H.: Isotopic fractionation associated with biosynthesis of fatty acids by a marine bacterium under oxic and anoxic conditions, Org. Geochem., 30, 1571-1579, 1999. 
Teskey, R. O. and McGuire, M. A.: Carbon dioxide transport in xylem causes errors in estimation of rates of respiration in stems and branches of trees, Plant Cell Environ., 25, 1571-1577, 2002.

Teskey, R. O. and McGuire, M. A.: $\mathrm{CO}_{2}$ transported in xylem sap affects $\mathrm{CO}_{2}$ efflux from Liquidambar styraciflua and Platanus occidentalis stems, and contributes to observed wound respiration phenomena, Trees, 19, 357-362, 2005.

Teskey, R. O., Saveyn, A., Steppe, K., and McGuire, M. A.: Origin, fate and significance of $\mathrm{CO}_{2}$ in tree stems, New Phytol., 177, 17-32, 2008.

Thompson, M. V.: Phloem: the long and the short of it, Trends Plant Sci., 11, 26-32, 2006.

Thompson, M. V. and Holbrook, N. M.: Scaling phloem transport: water potential equilibrium and osmoregulatory flow, Plant Cell Environ., 26, 1561-1577, 2003.

Thompson, M. V. and Holbrook, N. M.: Scaling phloem transport: information transmission, Plant Cell Environ., 27, 509519,2004

Trueman, R. J. and Gonzalez-Meler, M. A.: Accelerated belowground $\mathrm{C}$ cycling in a managed agriforest ecosystem exposed to elevated carbon dioxide concentrations, Glob. Change Biol., 11, 1258-1271, 2005.

Trumbore, S.: Carbon respired by terrestrial ecosystems - recent progress and challenges, Glob. Change Biol., 12, 141-153, 2006.

Van Bel, A. J. E.: The phloem, a miracle of ingenuity, Plant Cell Environ., 26, 125-149, 2003.

Van Bel, A. J. E. and Hafke, J. B.: Physiochemical determinants of phloem transport, in: Vascular Transport in Plants, edited by: Holbrook, N. M. and A., Z. M., Elsevier, Amsterdam, 19-44, 2005.

Vance, E. D. and Chapin, F. S.: Substrate limitations to microbial activity in taiga forest floors, Soil Biol. Biochem., 33, 173-188, 2001.

Vandenkoornhuyse, P., Mahe, S., Ineson, P., Staddon, P., Ostle, N., Cliquet, J. B., Francez, A. J., Fitter, A. H., and Young, J. P. W.: Active root-inhabiting microbes identified by rapid incorporation of plant-derived carbon into RNA, Proc. Natl. Acad. Sci. USA, 104, 16970-16975, 2007.

Van Der Meer, M. T. J., Schouten, S., Damsté, J. S. S., and Ward, D. M.: Impact of carbon metabolism on ${ }^{13} \mathrm{C}$ signatures of cyanobacteria and green non-sulfur-like bacteria inhabiting a microbial mat from an alkaline siliceous hot spring in Yellowstone National Park (USA), Environ. Microbiol., 9, 482-491, 2007.

Van Genuchten, M. T.: A closed-form equation for predicting the hydraulic conductivity of unsaturated soils, Soil Sci. Soc. Am. J., 44, 892-898, 1980.

Vargas, R., Baldocchi, D. D., Allen, M. F., Bahn, M., Black, T. A., Collins, S. L., Curiel Yuste, J., Hirano, T., Jassal, R. S., Pumpanen, J., and Tang J.: Looking deeper into the soil: biophysical controls and seasonal lags of soil $\mathrm{CO}_{2}$ production and efflux across multiple vegetation types, Ecol. Appl., 20, 1569-1582, 2010.

Vargas, R., Baldocchi, D. D., Bahn, M., Hanson, P. J., Hosman, K. P., Kulmala, L., Pumpanen, J., and Yang, B.: On the multitemporal correlation between photosynthesis and soil $\mathrm{CO} 2$ efflux: reconciling lags and observations, New Phytol., 191, 10061017, 2011.

Von Caemmerer, S. and Evans, J. R.: Determination of the average partial-pressure of $\mathrm{CO}_{2}$ in chloroplasts from leaves of several C-
3 plants, Austr. J. Plant Physiol., 18, 287-305, 1991.

Von Caemmerer, S., Millgate, A., Farquhar, G. D., and Furbank, R. T.: Reduction of ribulose-1,5-bisphosphate carboxylase/oxygenase by antisense RNA in the C-4 plant Flaveria bidentis leads to reduced assimilation rates and increased carbon isotope discrimination, Plant Physiol., 113, 469-477, 1997.

von Felten, S., Hattenschwiler, S., Saurer, M., and Siegwolf, R.: Carbon allocation in shoots of alpine treeline conifers in a $\mathrm{CO}_{2}$ enriched environment, Trees-Struct. Funct., 21, 283-294, 2007.

Walker, T. S., Bais, H. P., Grotewold, E., and Vivanco, J. M.: Root exudation and rhizosphere biology, Plant Physiol., 132, 44-51, 2003.

Wan, S. Q. and Luo, Y. Q.: Substrate regulation of soil respiration in a tallgrass prairie: Results of a clipping and shading experiment, Global Biogeochem. Cy., 17, 1054, doi:10.1029/2002gb001971, 2003.

Wardlaw, I.: Effect of water stress on translocation in relation to photosynthesis and growth II. Effect during leaf development in Lolium temulentum, Aust. J. Biol. Sci., 22, 1-16, 1969.

Warren, C. R.: Stand aside stomata, another actor deserves centre stage: the forgotten role of the internal conductance to $\mathrm{CO}_{2}$ transfer, J. Exp. Bot., 59, 1475-1487, 2008

Warren, C. R. and Adams, M. A.: Internal conductance does not scale with photosynthetic capacity: implications for carbon isotope discrimination and the economics of water and nitrogen use in photosynthesis, Plant Cell Environ., 29, 192-201, 2006.

Werner, C.: Do isotopic respiratory signals trace changes in metabolic fluxes?, New Phytol., 186, 569-571, 2010.

Werner, C. and Gessler, A.: Diel variations in the carbon isotope composition of respired $\mathrm{CO}_{2}$ and associated carbon sources: a review of dynamics and mechanisms, Biogeosciences, 8, 24372459, doi:10.5194/bg-8-2437-2011, 2011.

Werner, R. A. and Brand, W. A.: Referencing strategies and techniques in stable isotope ratio analysis, Rapid Commun. Mass Spectrom., 15, 501-519, 2001.

Werner, R. A., Buchmann, N., Siegwolf, R. T. W., Kornexl, B. E., and Gessler, A.: Metabolic fluxes, carbon isotope fractionation and respiration - lessons to be learned from plant biochemistry, New Phytol. 191, 10-15, 2011.

Werth, M. and Kuzyakov, Y.: Root-derived carbon in soil respiration and microbial biomass determined by ${ }^{14} \mathrm{C}$ and ${ }^{13} \mathrm{C}$, Soil Biol. Biochem., 40, 625-637, 2008.

Werth, M. and Kuzyakov, Y.: Three-source partitioning of $\mathrm{CO} 2$ efflux from maize field soil by ${ }^{13} \mathrm{C}$ natural abundance, J. Plant Nutr. Soil Sci., 172, 487-499, 2009.

Werth, M. and Kuzyakov, Y.: ${ }^{13} \mathrm{C}$ fractionation at the rootmicroorganisms-soil interface: A review and outlook for partitioning studies, Soil Biol. Biochem., 42, 1372-1384, 2010.

Whipps, J. M.: Carbon economy, in: The Rhizosphere, edited by: Lynch, J. M., Whiley, Chichester, 59-97, 1990.

Wiebe, H. H.: Photosynthesis in wood, Physiol. Plant., 33, 245 246, 1975.

Wieser, G. and Bahn, M.: Seasonal and spatial variation of woody tissue respiration in a Pinus cembra tree at the alpine timberline in the central Austrian Alps, Trees-Struct. Funct., 18, 576-580, 2004.

Wingate, L., Ogée, J., Burlett, R., Bosc, A., Devaux, M., Grace, J., Loustau, D., and Gessler, A.: Photosynthetic carbon isotope discrimination and its relationship to the carbon isotope signals 
of stem, soil and ecosystem respiration, New Phytol., 188, 576589,2010

Wittmann, C., Pfanz, H., Loreto, F., Centritto, M., Pietrini, F., and Alessio, G.: Stem $\mathrm{CO}_{2}$ release under illumination: corticular photosynthesis, photorespiration or inhibition of mitochondrial respiration?, Plant Cell Environ., 29, 1149-1158, 2006.

Wu, J., Brookes, P. C., and Jenkinson, D. S.: Formation and destruction of microbial biomass during the decomposition of glucose and ryegrass in soil, Soil Biol. Biochem., 25, 1435-1441, 1993.

Wynn, J. G., Bird, M. I., and Wong, V. N. L.: Rayleigh distillation and the depth profile of ${ }^{13} \mathrm{C} /{ }^{12} \mathrm{C}$ ratios of soil organic carbon from soils of disparate texture in Iron Range National Park, Far North Queensland, Australia, Geochim. Cosmochim. Acta, 69, 1961-1973, 2005.
Wynn, J. G., Harden, J. W., and Fries, T. L.: Stable carbon isotope depth profiles and soil organic carbon dynamics in the lower Mississippi Basin, Geoderma, 131, 89-109, 2006.

Xu, C. Y., Lin, G. H., Griffin, K. L., and Sambrotto, R. N.: Leaf respiratory $\mathrm{CO}_{2}$ is $\mathrm{C}$-13-enriched relative to leaf organic components in five species of C-3 plants, New Phytol., 163, 499-505, 2004.

Zhou, X., Wan, S. Q., and Luo, Y. Q.: Source components and interannual variability of soil $\mathrm{CO}_{2}$ efflux under experimental warming and clipping in a grassland ecosystem, Glob. Change Biol., 13, 761-775, 2007.

Ziemer, R. R.: Translocation of ${ }^{14} \mathrm{C}$ in Ponderosa pine seedlings, Can. J. Botany, 49, 167-171, 1971. 